\title{
Estimated Water and Nutrient Inflows and Outflows Lake Cochituate, Eastern Massachusetts, 1977-79
}

U.S. GEOLOGICAL SURVEY

Water-Resources Investigations Report 84-4315

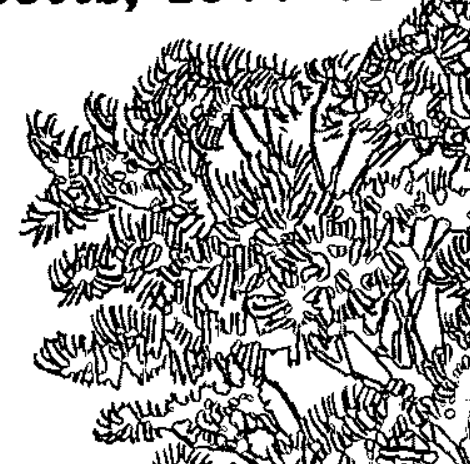

\section{(t)}

\section{2}

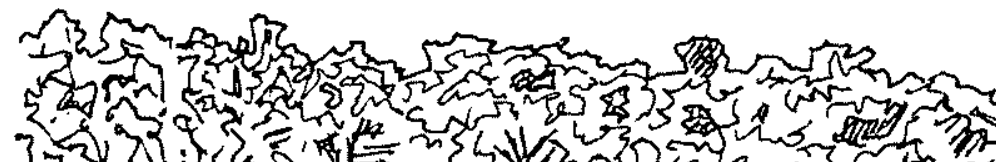

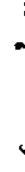

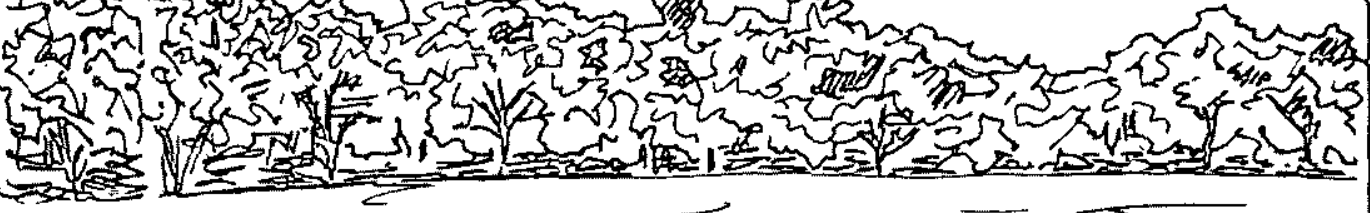
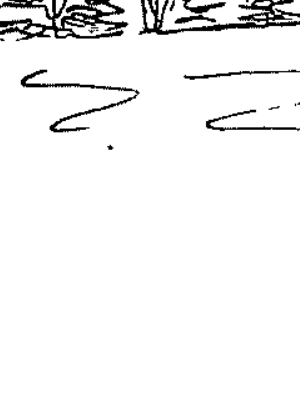

Prepared in cooperation with the

COMMONWEALTH OF MASSACHUSETTS

DEPARTMENT OF ENVIRONMENTAL QUALITY ENGINEERING

DIVISION OF WATER POLLUTION CONTROL 


\section{COVER}

Drawing on the cover depicts the intake structure to the Lake Cochituate Aqueduct located on the east side of North Pond, Lake Cochituate. This aqueduct was used from 1848 through 1931 when the reservoir was used as a source of drinking water for Boston. From 1931 through 1947, it was used as a standby reservoir because of the lake's deteriorating water quality and its small storage capacity. Finally, in 1947, the reservoir was designated a recreational lake under the ownership of the Massachusetts Department of Natural Resources (renamed the Department of Environmental Management). 
ESTIMATED WATER AND NUTRIENT INFLOWS AND OUTFLOWS

LAKE COCHITUATE, EASTERN MASSACHUSETTS, 1977-79

By Frederick B. Gay

U.S. GEOLOGICAL SURVEY

Water-Resources Investigations Report 84-4315

Prepared in cooperation with the

COMMONWEALTH OF MASSACHUSETTS

DEPARTMENT OF ENVIRONMENTAL QUALITY ENGINEERING

DIVISION OF WATER POLLUTION CONTROL

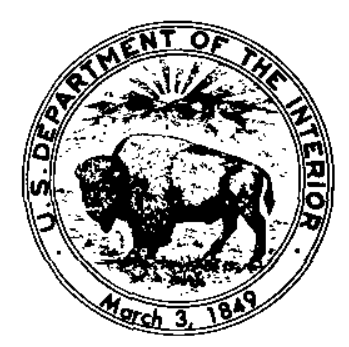

Boston, Massachusetts 1985 
WILLIAM P. CLARK, Secretary

GEOLOGICAL SURVEY

Dallas L. Peck, Director

For additional information, write to:

U.S. Geological Survey Water Resources Division 150 Causeway Street, Suite 1001 Boston, MA 02114
Copies of this report can be purchased from:

Open-File Services Section Western Distribution Branch

U.S. Geological Survey Box 25425, Federal Center Denver, CO 80225

Telephone: (303) 236-7476 
Abstract -

Introduction -

Purpose and scope

Acknowledgments

Geologic set ting -

Hydrologic setting

Precipitation-

Surface-water drainage system -

Ground-water flow system -

Methodology

Data collection and laboratory analyses-

Determinations of water volumes and nutrient loads-_a 9

Water volumes of surface water and precipitation-- 10

Nutrient loads in surface water and precipitation --_- 11

Water volumes of ground water- 13

Nutrient loads in ground water -

Significance of nutrient concentrations on lake-water quality-_- 16

Water and nutrient balances of Lake Cochituate

Water balance--

Nutrient balance -

Estimated water and nutrient inflows to Lake Cochituate from selected sources ---- 19

Surface water--

Water volumes -

Nutrient concentrations in major surface-water sources-- 19

Nutrient concentrations in storm sewers -

Nutrient loads in major surface-water sources -

Ground water -

Precipitation-1.- 50

Estimated water and nutrient outflows from Lake Cochituate-1 51

Surface outlet--

Evaporation--1..- 51

Summary and conclusions -...- 54

References cited - 58

\section{ILLUSTRATIONS}

(Plates are in pocket at back)

Plate 1. Map showing hydrologic-data collection sites and surface drainage divides of streams and representative storm sewers in the Lake Cochituate drainage basin, Massachusetts.

2. Hydrograph showing daily mean streamflow, estimated daily mean ground-water discharge, and dates of nutrient sample collection at Pegan Brook, and precipitation at National Weather Service Station in Framingham. 
Figure 1. Graph showing comparison of monthly precipitation at National Weather Service Station in Framingham for period November 1977 through May 1979 with average monthly precipitation

2. Schematic diagram of surface-water inflow and outflow sources including their drainage areas within the Lake Cochituate basin--.--

3. Graph showing concentrations of selected nitrogen and phosphorus species as a function of instantaneous streamflow at Beaverdam Brook gaging station

4. Diagram of idealized ground-water flow system with equations for estimating discharge to Lake Cochituate from the adjacent unconsolidated deposits

5. Graph showing monthly runoff entering Fisk Pond and Lake Cochituate from surface-water sources for the period April 1978 through March 1979

6. Graph showing estimated monthly total nitrogen loads entering Fisk Pond and Lake Cochituate from surface-water sources for the period April 1978 through March 1979

7. Graph showing estimated monthly total phosphorus loads entering Fisk Pond and Lake Cochituate from surface-water sources for the period April 1978 through March 1979

8. Graph showing percent contribution by month of yearly runoff, and total nitrogen and total phosphorus loads entering Lake Cochituate from surface-water sources for the period April 1978 through March 1979

9. Graph showing percent contribution by month of yearly runoff, and total nitrogen and total phosphorus loads at Beaverdam Brook gaging station

10. Hydrogeologic section $\mathrm{A}-\mathrm{A}^{\prime}$ through observation wells $\mathrm{F} 1 \mathrm{~W}-84,-90$, and -91 , and F1W-87 through -89 at site 6

11. Hydrograph showing daily water levels in North Pond, Lake Cochituate, at the Cochituate aqueduct intake structure

12. Schematic diagram of water volumes entering and leaving Fisk Pond and Lake Cochituate from major sources for the period April 1978 through March 1979

13. Schematic diagram of total nitrogen and total phosphorus loads entering and leaving Fisk Pond and Lake Cochituate from major sources for the period April 1978 through March 1979- 


\section{TABLES}

Table 1. Analytical and calculated nitrogen and phosphorus species

Page determined by Survey Laboratory

2. Concurrent instantaneous discharges of Beaverdam and Course Brooks and Fisk Pond outlet during periods of no overland runoff- 10

3. Equations relating total phosphorus concentration to instantaneous streamflow for major surface-water sources -

4. Hydraulic conductivity of aquifer materials 15

5. Monthly runoff entering Fisk Pond and Lake Cochituate from surface-water sources and precipitation--- 20

6. Maximum, average, and minimum concentrations of nutrient species entering Fisk Pond and Lake Cochituate from major surface-water sources -

7. Maximum, average, and minimum concentrations of nutrient species entering Fisk Pond and Lake Cochituate from representative storm sewers and major surface-water sources--------

8. Maximum and minimum concentrations of nutrient species entering Fisk Pond and Lake Cochituate from representative storm sewers and major surface-water sources -

9. Concentrations of nutrient species entering Lake Cochituate from representative storm sewers during the April 26-27, 1979, rainstorm -

10. Estimated monthly nutrient loads entering and leaving Fisk Pond from surface-water sources

11. Estimated monthly nutrient loads entering Lake Cochituate from surface-water sources

12. Estimated monthly runoff and nutrient loads entering Middle Pond from ground-water sources at site 2

13. Monthly pumpage of ground water from Springvale and Evergreen well fields for the period April 1978 through March 1979

14. Estimated monthly runoff and nutrient loads entering North Pond from ground-water sources at site 5

15. Average concentrations of total nitrogen and total phosphorus in ground water at selected sites adjacent to Lake

Cochituate - -

16. Nutrient concentrations, water volumes, and estimated nutrient loads entering Lake Cochituate from two precipitation events at National Weather Service station in Framingham--

17. Nutrient concentrations, volume of monthly runoff, and estimated nutrient loads leaving Lake Cochituate at its surface outlet

18. Estimated nutrient loads entering Fisk Pond and Lake Cochituate from surface-water sources for the period April 1978 through

March 1979 


\section{METRIC CONVERSION FACTORS}

The following factors may be used to convert inch-pound units to the International System of Units (SI).

\begin{tabular}{|c|c|c|}
\hline Multiply inch-pound units & By & To obtain SI Units \\
\hline \multicolumn{3}{|c|}{ Length } \\
\hline $\begin{array}{l}\text { inch } \\
\text { foot } \\
\text { mile }\end{array}$ & $\begin{array}{l}2.540 \\
0.254 \\
0.3048 \\
1.609\end{array}$ & $\begin{array}{l}\text { centimeter }(\mathrm{cm}) \\
\text { decimeter }(\mathrm{dm}) \\
\text { meter }(\mathrm{m}) \\
\text { kilometer }(\mathrm{km})\end{array}$ \\
\hline \multicolumn{3}{|c|}{ Area } \\
\hline square mile $\left(\mathrm{mi}^{2}\right)$ & 2.590 & square kilometer $\left(\mathrm{km}^{2}\right)$ \\
\hline \multicolumn{3}{|c|}{ Volume } \\
\hline $\begin{array}{l}\text { cubic foot }\left(\mathrm{ft}^{3}\right) \\
\text { gallon (gal) } \\
\text { million gallons (Mgal) }\end{array}$ & 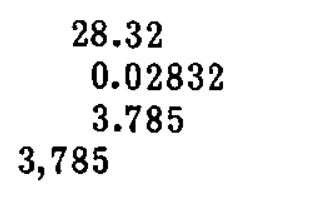 & $\begin{array}{l}\text { cubic decimeter }\left(\mathrm{dm}^{3}\right) \\
\text { cubic meter }\left(\mathrm{m}^{3}\right) \\
\text { liter }(\mathrm{L}) \\
\text { cubic meter }\left(\mathrm{m}^{3}\right)\end{array}$ \\
\hline \multicolumn{3}{|c|}{$\underline{\text { Flow }}$} \\
\hline $\begin{array}{l}\text { cubic foot per day }\left(\mathrm{ft}^{3} / \mathrm{d}\right) \\
\text { gallon per minute }(\mathrm{gal} / \mathrm{min})\end{array}$ & $\begin{array}{l}28.32 \\
0.02832 \\
3.785 \\
3.785\end{array}$ & $\begin{array}{l}\text { cubic decimeter per day }\left(\mathrm{dm}^{3} / \mathrm{d}\right) \\
\text { cubic meter per day }\left(\mathrm{m}^{3} / \mathrm{d}\right) \\
\text { liter per minute }(\mathrm{L} / \mathrm{min}) \\
\text { cubic decimeter per minute } \\
\left(\mathrm{dm}^{3} / \mathrm{min}\right)\end{array}$ \\
\hline $\begin{array}{l}\text { million gallons per } \\
\text { year (Mgal/yr) }\end{array}$ & $\begin{array}{l}3.785 \times 10^{-3} \\
3,785\end{array}$ & $\begin{array}{l}\text { cubic meter per minute }\left(\mathrm{m}^{3} / \mathrm{min}\right) \\
\text { cubic meter }\left(\mathrm{m}^{3} / \mathrm{yr}\right)\end{array}$ \\
\hline & Mass & \\
\hline pound, avoirdupois (1b) & 453.6 & gram (g) \\
\hline \multicolumn{3}{|c|}{ Hydraulic conductivity } \\
\hline foot per day (ft/d) & $\begin{array}{l}3.048 \\
0.3048\end{array}$ & $\begin{array}{l}\text { decimeter per day }(\mathrm{dm} / \mathrm{d}) \\
\text { meter per day }(\mathrm{m} / \mathrm{d})\end{array}$ \\
\hline \multicolumn{3}{|c|}{ Transmissivity } \\
\hline square foot per day $\left(\mathrm{ft}^{2} / \mathrm{d}\right)$ & $\begin{array}{l}9.290 \\
0.0929\end{array}$ & $\begin{array}{l}\text { square decimeter per day }\left(\mathrm{dm}^{2} / \mathrm{d}\right) \\
\text { square meter per day }\left(\mathrm{m}^{3} / \mathrm{d}\right)\end{array}$ \\
\hline
\end{tabular}


ESTIMATED WATER AND NUTRIENT INFLOWS AND OUTFLOWS, LAKE COCHITUATE, EASTERN MASSACHUSETTS, 1977-79

By Frederick B. Gay

\begin{abstract}
Streamflow was the major source of water and nutrients (nitrogen and phosphorus) entering Lake Cochituate, followed by ground water, and then precipitation during April 1978 through March 1979. Compared to all sources during that period, streams contributed 7,217 million gallons (a little over 82 percent) of water; 63,000 pounds (between 50 and 60 percent) of nitrogen; and 3,000 pounds (94 percent) of phosphorus. A little over 60 percent of all the water that entered Lake Cochituate flowed from Fisk Pond. This single source transported about 38,000 pounds of nitrogen and 2,000 pounds of phosphorus.

The estimated total phosphorus load of 2,180 pounds transported to the lake's South Pond from Fisk Pond and Pegan Brook from April 1978 through March 1979 is sufficient to produce a total phosphorus concentration of 0.031 milligrams per liter using the classic equation by Vollenweider. This concentration is 50 percent higher than the critical total phosphorus concentration of 0.02 milligram per' liter that is commonly accepted as the limit at which aquatic-plant growth becomes excessive and the lake exhibits eutrophic conditions.

Ground-water inflow to Lake Cochituate occurs along its shoreline except at the north end of Lake Cochituate's North Pond where natural seepage from the lake is occurring and at locations on the lake's Middle and South Ponds where municipal wells induce infiltration of lake water amounting to 1,228 million gallons for that period. Discharge of ground water to the lake was estimated to range from 462 to 816 million gallons and transported from 31,000 to 55,000 pounds of nitrogen and from 46 to 82 pounds of phosphorus.

Bulk precipitation was estimated to contribute about the same volume of water to the' lake as ground water but double its phosphorus load. However, the load of nitrogen from bulk precipitation (8,000 pounds) was the smallest of any source.
\end{abstract}

\title{
INTRODUCTION
}

Lake Cochituate is about 16 miles west of Boston, Massachusetts, in the southeastern part of Middlesex County. The lake drains $17.7 \mathrm{mi}^{2}$ at its outlet from within the towns of Ashland, Framingham, Natick, Sherborn, and Wayland (pl. 1). Principal subbasins that contribute water to the lake are Beaverdam, Course, Pegan, and Snake Brooks and Fisk Pond. Surface drainage from the lake's outlet flows through Cochituate Brook into the Sudbury River at Framingham. The Sudbury River flows northeastward into the Concord River, a tributary of the Merrimack River.

Topographic relief in the Lake Cochituate drainage basin is moderate-altitudes range from 130 feet at the base of the lower dam at the lake's outlet to about 400 feet at 
the tops of many small rounded hills along the drainage divide. This moderate relief causes low-stream gradients which allow wetlands to form adjacent to stream channels, particularly in the Beaverdam and Course Brook basins. A large part of the Lake Cochituate drainage basin is covered by residential, commercial/industrial, and public/ institutional development. Only in the headwaters of Beaverdam, Course, and .Snake Brook basins is there a rural environment of open fields, wetlands, and forests.

Lake Cochituate was called .Long Pond before the City of . Boston acquired the water-supply rights in 1846 , built a dam to raise the water level 9 feet, and renamed the enlarged water body Cochituate Reservoir. In 1859, the main dam was raised, another dam was built just below the main dam to reduce the pressure on the main dam, and dikes were constructed along several sections of shoreline to raise the reservoir level an additional 4 feet. From late 1848 through late 1931, the reservoir was used as a source of drinking water for Boston. From late 1931 to sometime in 1947, it was used only as a standby reservoir because of the lake's deteriorating water-quality conditions and its small storage capacity. Finally, in 1947, the reservoir was designated a recreational lake under the ownership of the Massachusetts Department of Natural Resources (renamed the Department of Environmental Management).

The lake is managed for recreational purposes by the Massachusetts Division of Forests and Parks, and the recreational departments of Framingham, Natick, and Wayland. Through induced infiltration to nearby wells, the lake is also an indirect source of drinking water for Natick and of cooling water for the U.S. Army Natick Laboratories. In addition, Framingham's municipal-supply wells, located in the riverine wetlands between the Sudbury River and the northern end of the Lake Cochituate, probably intercept some of the lake water that seeps into unconsolidated deposits at the north end of the lake when the wells are pumped for an extended period of time.

Over the years, point and nonpoint sources of pollutants generated by increasing urbanization and industrial expansion have accelerated nutrient enrichment in the lake. Part of the drainage area immediately adjacent to the lake has undergone intense urbanization in recent years with disposal of domestic sewage through septic tanks and leach fields. During the summer of 1968 , recreational use was so severely impaired by algal growth that copper sulfate treatments were applied four times between June and September to reduce high algal counts (Cortell and Associates, Inc., 1972). At the start of this study in July 1977, the lake's various ponds exhibited mesotrophic to eutrophic characteristics similar to those described in a report of the lake's condition by the Boston College Environmental Center (1972).

Because of the highly eutrophic condition of Lake Cochituate, the Commonwealth of Massachusetts and local groups, such as the Lake Cochituate Watershed Association, sought to assess and to improve the trophic status of Lake Cochituate under provisions of the Massachusetts Clean Waters Act and the Federal Government's Clean Lakes Program. The Clean Lakes Program was established by Section 314, P.L. (Public Law) 92-500, of the Federal Water Pollution Control Act of 1972, as amended under P.L. 95-217, the Clean Water Act of 1977. This program directs the U.S. Environmental Protection Agency to assist states in controlling sources of pollution to publicly owned freshwater lakes, and to assist in restoring lakes which have degraded water quality. Therefore, to help local, State, and Federal agencies in their efforts to reduce the eutrophic conditions in Lake Cochituate, the Survey (U.S. Geological Survey), in cooperation with the Massachusetts Department of Environmental Quality Engineering, Division of Water Pollution Control, studied nutrient inflows and outflows from the lake.

This study was intended to provide part of the information needed by the MDWPC (Massachusetts Division of Water Pollution Control) to develop and to design effective water-quality restoration and management programs for Lake Cochituate. This study was conducted simultaneously with a MDWPC study of the lake's physical, chemical, and biological properties so that MDWPC could appraise the lake's nutrient status (Beskenis and others, 1982). 


\section{Purpose and Scope}

This report describes the results of the Survey's study to identify and to determine the magnitudes of the major sources of nutrients (nitrogen and phosphorus) to Lake Cochituate from both surface and ground water and to determine the magnitude of nutrients leaving the lake at its outlet. The major sources that were identified for evaluation were Beaverdam, Course, Snake, and Pegan Brooks, Fisk Pond, which is fed by Beaverdam and Course Brooks, and the unconsolidated deposits adjacent to the lake.

This report is based on measurements made over the period July 1977 through July 1979 and presents information on the: (1) Quantity of surface water, its nutrient concentrations, and an estimate of the nutrient loads flowing into Lake Cochituate from each of its major tributaries listed above and flowing out at its outlet; (2) concentrations of nutrients in water flowing directly into the lake from representative storm sewers around the lake; (3) direction of ground-water flow, the quantity of ground water, its nutrient concentrations, and an estimate of the nutrient loads flowing into the lake at representative sites adjacent to the lake; and (4) areas around the shore of the lake where lake water is seeping into the unconsolidated deposits.

\section{Acknowledgments}

The author wishes to acknowledge and to thank the many persons and organizations who have kindly given their time, inform ation, and guidance to this study. In particular, acknowledgments are given to Francis G. Sullivan of the Francis G. Sullivan Drilling Co., Inc., for well-drilling and material-sampling services and thanks to personnel of the: engineering departments of the Towns of Framingham, Natick, and Wayland for providing information and maps of storm-sewer drainage; MDC (Metropolitan District Commission) at the Framingham office and at the Lake Cochituate Park Headquarters for providing lake-level data; and Massachusetts Division of Forests and Parks at Lake Cochituate State Park Headquarters and the Town of Natick for providing access to their property to operate stream-gaging stations and to collect water samples.

\section{GEOLOGIC SETTING}

A bedrock valley underlies Lake Cochituate, and the axis of this valley trends north to south paralleling the long axis of the lake. Depth to the bedrock surface ranges from 0 to 200 feet below land surface; however, bedrock crops out at a few locations.

In the Lake Cochituate drainage basin, bedrock is overlain by unconsolidated glacial deposits. Surficial deposits of till are limited to the eastern side of the basin and well sorted stratified deposits cover the remainder of the basin. The stratified deposits are ice-contact, deltaic, and lacustrine in origin and were laid down in or adjacent to postglacial Lake Charles. They are predominantly thinly layered silt and sand interbedded with fine sand and silty clay or clay with isolated layers of sand and gravel (Gay, 1981). Some deposits composed mainly of sand and gravel are also present. The thickness of the deposits ranges up to 200 feet.

The four ponds which comprise Lake Cochituate were formed during deglaciation where large blocks of residual ice remained in the deep bedrock valley underlying the present lake. Clay, silt, sand, and gravel carried by meltwater were deposited around and over the ice blocks during the melting of the glacier. In time, the ice blocks melted allowing material deposited on top of and in contact with them to slump into the depressions left by the melted ice. The ponds formed in these depressions.

Detailed descriptions of the surficial geology, including $1: 24,000$ scale maps showing the type and origin of the surficial deposits, are available for the Framingham (Nelson, 1974a), Natick (Nelson, 1974b), and Holliston (Volckmann, 1975) quadrangles. 
Part of the precipitation falling on the Lake Cochituate drainage basin lands directly on surface-water bodies such as wetlands, ponds, lakes, or stream channels, or flows over the land surface into these surface-water bodies. This water is considered part of the surface-water flow system. The rest of the precipitation falling on the land surface either evaporates or moves into the unconsolidated deposits to be transpired by vegetation or to become part of the ground-water flow system for later discharge to surface-water bodies.

\section{Precipitation}

Monthly precipitation quantities falling onto Lake Cochituate are shown in figure 1 for the period when the majority of the hydrologic data used for this study were collected. These precipitation data were collected at a National Weather Service Station located between Middle and North Ponds of Lake Cochituate (pl. 1). During this period, November 1977 through May 1979, there were months of above and below normal precipitation. Except for 2 months (both January), departures of monthly precipitation as determined from the average monthly values of the 1941-70 base period used by the National Weather Service ranged from 2.17 inches above to 2.15 inches below these long-term monthly averages or about +65 percent of the monthly average. However, departures for January 1978 and 1979 were even larger, 5.02 and 9.38 inches, respectively, above the average monthly January precipitation of the base period. Total precipitation for November 1977 through May 1979 was 78.23 inches. This was 8.19 inches greater than the total precipitation for a 19 -month period from the National Weather Service's 1941-70 base period.

Precipitation during this period was sufficient to maintain monthly streamflow and ground-water levels in the vicinity of the Lake Cochituate drainage basin in the normal or above normal range for all but 3 months (U.S. Geological Survey, issued monthly). Only during the months of September, November, and December 1978, were monthly streamflows in the deficient range and October-December 1978, were monthly ground leveis below normal.

Monthly streamflow and ground levels remained in the normal or above normal range because snowmelt from storms in January and February 1978 and rain in January 1979 recharged ground water. This recharge raised water levels in the unconsolidated deposits and drainage from these deposits sustained streamflow during the following months when slightly below normal precipitation occurred. In addition, nearly all the precipitation that falls during the summer months goes to soil moisture replenishment and evapotranspiration rather than to streamflow.

\section{Surface-Water Drainage System}

The total surface area of the four ponds that comprise Lake Cochituate is $0.92 \mathrm{mi}^{2}$. The four ponds are connected in series through which water flows northward from South Pond to Carling, Middle, and North Ponds before discharging to Cochituate Brook, the outlet of Lake Cochituate (pl. 1). Maximum water depths in South, Carling, Middle, and North Ponds are 69, 30, 60, and 69 feet, respectively (Beskenis and others, 1982); whereas, the depth of water at the connections between ponds is less than 10 feet. This allows each pond to act as an independent sedimentation or settling basin. Beskenis and others (1.982) reports that the volumes of South, Carling, Middle, and North Ponds are 1,511.5, 53.6, 1,179.7, and 1,750.1 Mgal, respectively, totaling approximately 4,500 Mgal. 


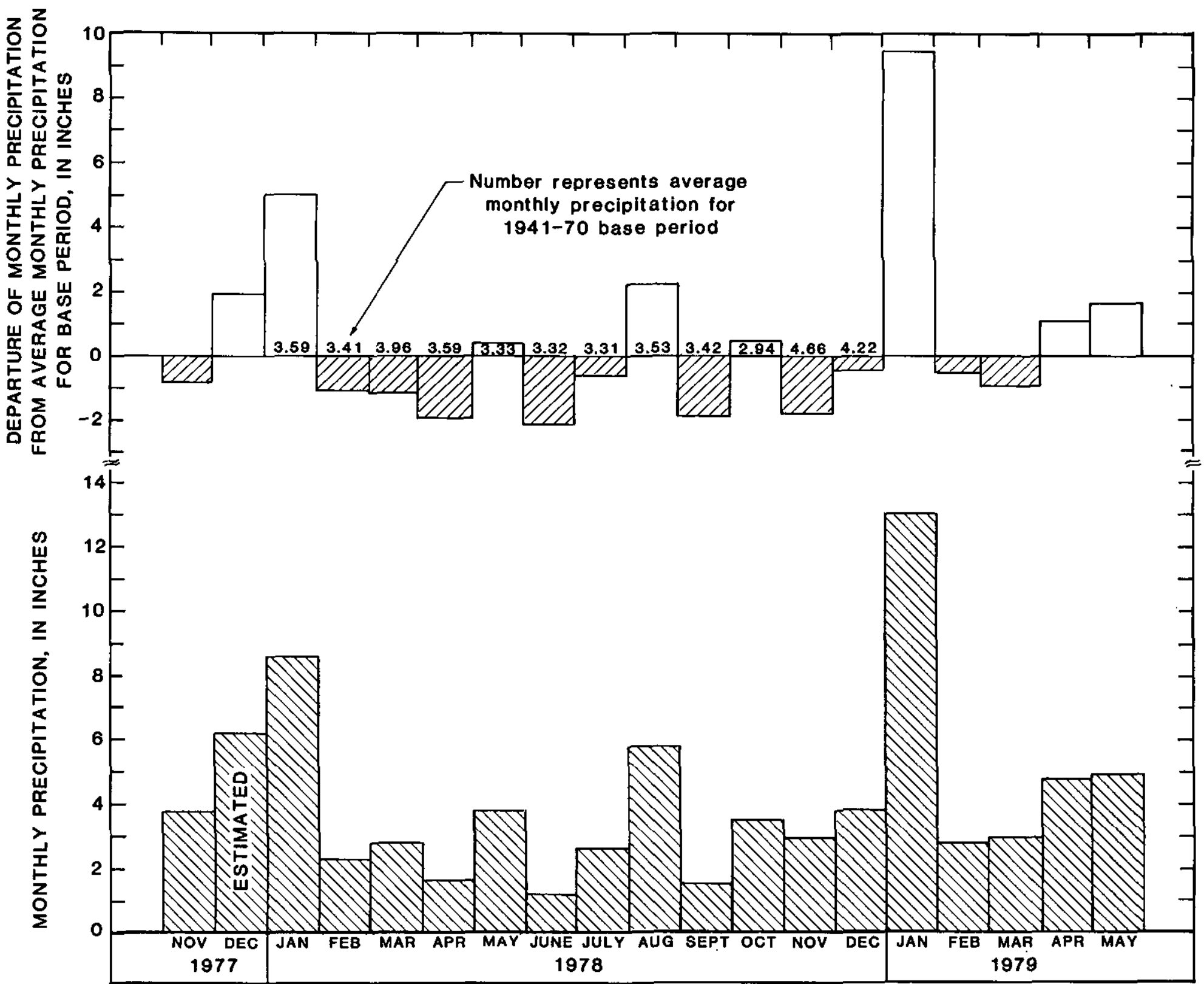

Figure 1.--Comparison of monthly precipitation at National Weather Service Station in Framingham for period November 1977 through May 1979 with average monthly precipitation for base period, 1914-70. 
The major surface-water sources to Lake Cochituate, listed in order of decreasing drainage area size, are Fisk Pond, and Snake and Pegan Brooks. They are perennial pond and (or) stream systems that drain approximately 80 percent of the lake's drainage basin. Fisk Pond flows into South Pond (fig. 2); whereas, Pegan and Snake Brooks flow directly into South and North Ponds, respectively. The principal surface-water source to the lake is Fisk Pond which drains about 65 percent of the basin. However, Beaverdam and Course Brooks are each tributary to Fisk Pond and their combined drainage represents 60 percent of the Lake Cochituate drainage basin. Indirectly then, these two streams are the major surface-water sources to the lake. In addition, many storm sewers that drain urban areas around the lake discharge directly into the lake accounting for approximately 15 percent of the drainage basin. Also, Lake Cochituate's surface area accounts for 5 percent of the drainage area.

\section{Ground-Water Flow System}

Movement of ground water is governed principally by the size and degree of interconnection of the pores or openings within the subsurface material and by the pressure or hydraulic head exerted by water within the subsurface material. The hydraulic head at any point in a ground-water flow system is a measure of the potential energy of the fluid, and ground water flows in the direction of decreasing head. This flow occurs in the pores of the unconsolidated materials and in the joints and fractures in the bedrock. In the Lake Cochituate drainage basin, the principal direction of ground-water movement is from recharge areas on the tops and sides of hills to discharge areas (wetlands, ponds, lakes, and stream channels) in the low-lying areas. During periods of little or no precipitation, such as during the summer months, streamflow is primarily sustained by ground-water discharge from unconsolidated deposits and not by immediate runoff from precipitation events. For the period April 1978 through March 1979, about half of the annual streamflow from Pegan Brook was ground-water discharge. The other half was derived from precipitation flowing over land surface.

The water table in the vicinity of the lake's shoreline is above lake level at some locations and below lake level at others. At locations where the water table is above lake level, ground water is seeping into the lake. Where the water table is below lake level, lake water is seeping from the lake into the unconsolidated deposits.

A water table lower than lake level forms where: (1) Natural hydraulic gradients direct ground-water flow away from Lake Cochituate toward downgradient surface-water bodies; and (2) large capacity pumping wells located in the aquifer adjacent to the lake create a localized cone of depression in the water table. For example, at the northern end of North Pond the water table slopes steeply away from the pond indicating that lake water is seeping into the unconsolidated deposits and moving toward the Sudbury River. This natural ground-water discharge from the lake develops because the transmissivity of the surficial deposits and the difference in heads between the recharge zone (lake) and discharge zone (Sudbury River) are too great for precipitation to recharge a sufficient quantity of water to sustain a water-table mound between the lake and the river. In another example, municipal well fields operated by the Town of Natick near the east shore of Middle Pond and the north shore of South Pond intercept and remove ground water that would normally discharge to the ponds. In addition, these wells induce pond water to recharge the aquifer. Most of this municipal pumpage is not returned to the basin as Natick's sewage is treated and discharged outside the basin. However, there are some septic tanks within the basin, but their return contribution to the basin is considered minor when compared to the total volume of water pumped from these wells. This withdrawal for public supply is a major influence on ground-water movement in the basin. 


\section{SUDBURY RIVER}

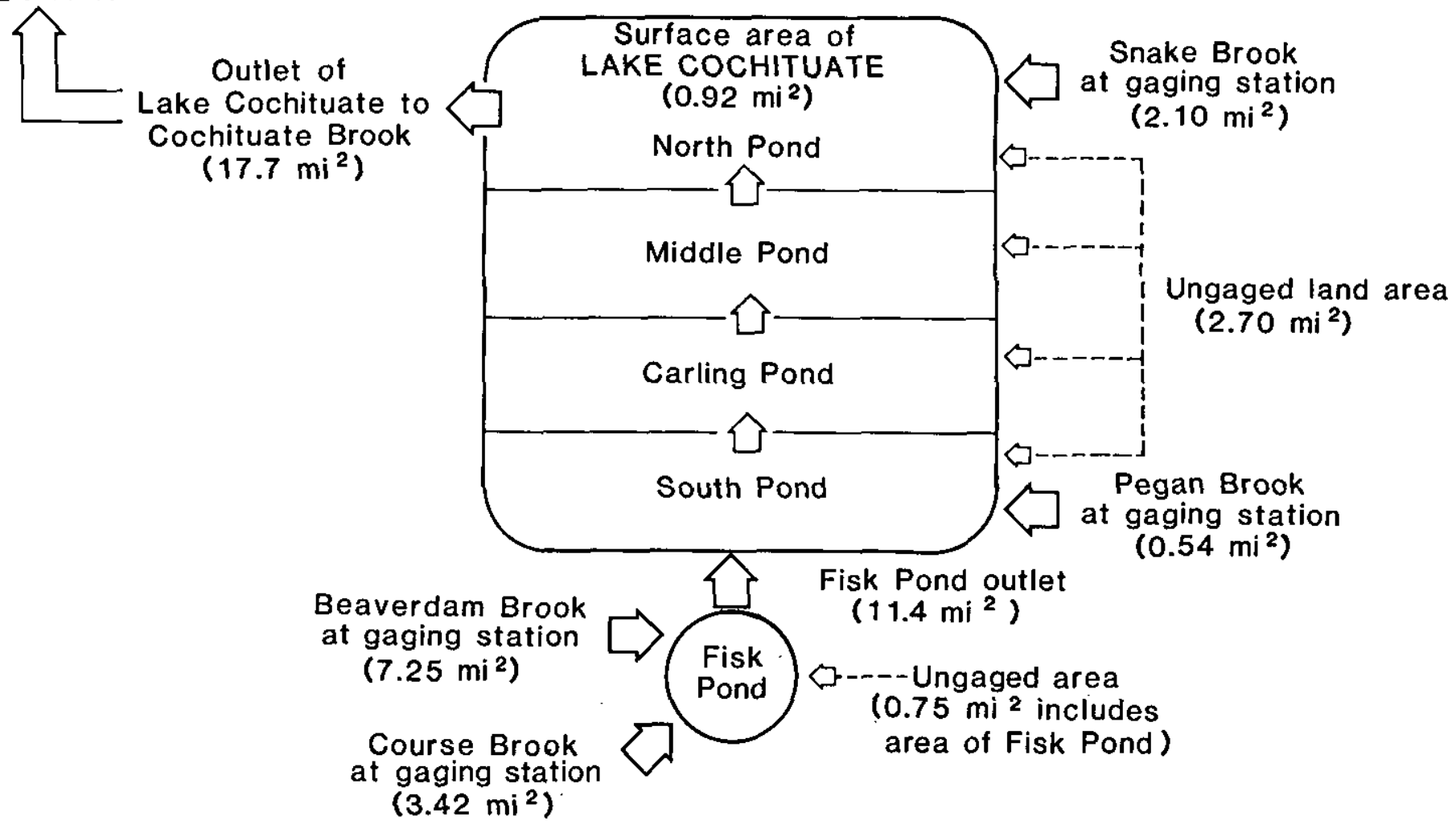

NOTE: Arrows indicate direction of surface-water flow

Figure 2.--Schematic diagram of surface-water inflow and outflow sources including their drainage areas within the Lake Cochituate basin. 


\section{METHODOLOGY}

\section{Data Collection and Laboratory Analyses}

A network of data-collection sites was established to measure the various components of the hydrologic system that contribute water to or remove water from Lake Cochituate. This network included sites established for this study by the Survey as well as sites already established by other organizations. Data-collection activities for this study covered the period July 1977 through July 1979. Plate 1 shows the locations of the sites referred to in this report at which data were collected. Descriptions of the location of these and other sites and tabulations of the data collected at them were published separately (Gay, 1981).

Daily streamflow was measured at five continuous-record gaging stations established near the mouths of Beaverdam, Course, Pegan, and Snake Brooks, and the outlet of Lake Cochituate. Water samples for nutrient analysis were collected monthly at these gaging stations and Fisk Pond outlet. All the stream-gaging stations were operated for a 19-month period from November 1977 through May 1979. In addition, instantaneous discharges and water samples for nutrient analysis were collected at the outlets of 18 storm sewers discharging directly into the lake as well as at the gaging stations and at Fisk Pond outlet for the December 8 and 9, 1978, January 24-26 and April 26 and 27, 1979, rainstorms. The storm sewers were selected to provide overland runoff samples from: (1) A number of representative urban areas including sewered residential, nonsewered residential (septic tanks), commercial, light industrial, and highways; (2) large stormsewer systems; (3) storm sewers that are dry during nonstorm periods as determined by an October 1978 field inspection; and (4) storm sewers that have no cross connections with sanitary sewers. Also, water samples for nutrient analysis of rainfall were collected at the National Weather Service Station in Framingham for the December and April storms described above.

Water-level data and water samples for nutrient analysis of ground water were obtained from May 1978 through July 1979 from 29 observation wells located adjacent to or near the shore at seven sites around the lake. Water levels in the observation wells were measured monthly and referenced to sea level by differential leveling. Water samples were collected approximately every 3 months from seven observation wells located adjacent to the shoreline and once or twice during this period from 17 additional observation wells located near the lake. Also, 30 lithologic samples from wells located adjacent to the shoreline were collected for analysis of particle-size distribution.

Data provided by other organizations used in this study include daily amounts of precipitation from the National Weather Service Station, located at the MDC Lake Cochituate Headquarters in Framingham, and daily lake levels from the MDC. gage located at the restored Lake Cochituate Aqueduct Intake Structure on the east shore of North Pond.

All the water-quality samples were collected by Survey personnel using depthintegrating sampling techniques described in Guy and Norman (1970) for surface waters and standard techniques described in Wood (1976) for ground waters.

The water samples for nitrogen and phosphorus analyses were treated in the field according to standard Survey methods (Friedman, 1978). These unfiltered and chilled water samples were shipped by air mail to the Survey's laboratory in Atlanta, Georgia, for chemical analysis according to methods described in Skougstad and others (1979). Table 1 is a list of analy tical and calculated determinations performed on these samples. 
Table 1.-Analytical and calculated nitrogen and phosphorus species determined by Survey Laboratory

Analy tical species

Calculated species

Total ammonia nitrogen as nitrogen

*Total ammonia plus organic nitrogen as nitrogen

*Total nitrite nitrogen as nitrogen

Total nitrite plus nitrate nitrogen as nitrogen

Total or thophosphate phosphorus as phosphorus

Total phosphorus as phosphorus
Total organic nitrogen as nitrogen

*Total nitrate nitrogen as nitrogen

Total nitrogen as nitrogen

* Not reported in tables

The concentrations of the chemical species listed in table 1 and elsewhere in this report are in milligrams per liter of nitrogen or phosphorus. Consistent units are used to enable comparison between the various species. The use of the word total before any of the listed species indicates that the reported concentration includes the amount of dissolved plus suspended material present at the time of analysis. According to Skougstad and others $(1979$, p. 4) the term total, "...is used only when the analytical procedure assures measurement of at least 95 percent of the constituent present in both the dissolved and suspended phases of the sample." Several authors have suggested total concentration can be used as a reasonable estimate of the ability of a water body to support primary productivity because bacterial decomposition and (or) chemical reaction of the suspended particulate matter releases nutrients for later assimilation by primary producers. This last statement is further supported by three authors. Reid and Wood (1976, p. 233) state that, "The measure of the total organic nitrogen content is, however, a valuable indication of the productivity of the body of water, for certainly most of the substance will ultimately be transformed into states which can enter into production of living matter". Wetzel (1975, p. 236) states that, "It is therefore more relevant to the question of increasing algal productivity to view the phosphorus concentrations in terms of the total phosphorus, since most of the phosphorus is bound in the particulate component at any given time".

\section{Determinations of Water Volumes and Nutrient Loads}

Monthly water volumes and their nutrient loads were determined for the period April 1978 through March 1979 and are used throughout this report for comparative purposes. This period corresponds to the onset of one spring circulation period in the lake to the start of the next spring circulation period. During the spring circulation as well as the fall circulation, lake water experiences a "turnover" and becomes homogeneous with respect to its physical and chemical properties for a short period of time. Limnologists consider the spring circulation period, which is just before the start of major algal blooms, a good time to begin collecting lake data because of the homogeneity of the lake's water column. In addition, this yearly period will show the cyclical pattern of monthly streamflow and their nutrient loads discharging into Lake Cochituate. Precipitation for this 12-month period totaled 45.09 inches and was 1.81 inches above average when compared to the National Weather Service's 1941-70 base period. 
Daily mean streamflow values at the gaging stations and measurements of instantaneous streamflow were calculated by standard methods of the U.S. Geological Survey as described in Benson and Dalrymple (1967), Bodhaine (1968), Buchanan (1969), Buchanan and Somers (1968), and Carter and Davidian (1968). Daily mean streamflow values were summed to obtain monthly discharge for all the gaging stations.

Surface-water flow from $13.3 \mathrm{mi}^{2}$ (75 percent) of land surface draining into Lake Cochituate and surface-water flow from $17.7 \mathrm{mi}^{2}$ of land and lake surfaces draining from the outlet of Lake Cochituate was determined at stream-gaging stations. An estimate of the surface-water flow from the intervening $3.45 \mathrm{mi}^{2}$ of ungaged area draining into the lake complex, exclusive of the $0.92 \mathrm{mi}^{2}$ Lake Cochituate's surface area, was computed as described below.

A hydrographic separation technique (Linsley and others, 1975) was applied to daily streamflow data collected at Pegan Brook gaging station to determine its surface-water and ground-water discharge components (pl. 2). The daily discharges of the surface-water component were summed to obtain the monthly values. Each monthly value was divided by the drainage area at the Pegan Brook gaging station to obtain monthly discharge per square mile. These unit discharge values were considered transferable to the ungaged land areas that have similar urban development and hydrologic characteristics as Pegan Brook. Monthly surface-water discharge values for the $0.75 \mathrm{mi}^{2}$ of ungaged area between the Beaverdam and Course Brook stream gages and the outlet of Fisk Pond, and the $2.70 \mathrm{mi}^{2}$ of ungaged area draining directly into Lake Cochituate were estimated by this method.

Monthly surface-water runoff from Fisk Pond outlet was determined by adding the surface-water runoff from Beaverdam and Course Brooks gaging stations to the estimated surface-water runoff from the ungaged area between these gages and the outlet of Fisk Pond. A comparison of concurrent instantaneous streamflows entering Fisk Pond from Beaverdam and Course Brooks gaging stations and measured discharges leaving Fisk Pond (table 2) during periods of no overland runoff was made to ascertain whether or not there is any measurable ground-water discharge from the unconsolidated deposits between the gaging stations and the outlet of Fisk Pond. After the measurement error of +5 percent is applied to the sum of instantaneous discharges at the Course and Beaverdam Brooks gaging stations (column 4, table 2) and to the discharge measurements made at Fisk Pond outlet (column 5, table 2), the data indicate that negligible quantities of ground water seep into Fisk Pond.

The amount of precipitation falling onto the surface of Lake Cochituate was computed by multiplying the surface area of the lake by the amount of precipitation recorded at the National Weather Service gage in Framingham.

Table 2.-Concurrent instantaneous discharges, in cubic feet per second, of Beaverdam and Course Brooks and Fisk Pond outlet during periods of no overland runoff

\begin{tabular}{lcccc}
\hline Date & $\begin{array}{c}\text { Instantaneous } \\
\text { discharge of } \\
\text { Beaverdam Brook } \\
\text { at gaging station }\end{array}$ & $\begin{array}{c}\text { Instantaneous } \\
\text { discharge of } \\
\text { Course Brook } \\
\text { at gaging station }\end{array}$ & $\begin{array}{c}\text { Sum of instantaneous } \\
\text { discharges of } \\
\text { Course and } \\
\text { Beaverdam Brooks } \\
\text { at gaging stations }\end{array}$ & $\begin{array}{c}\text { Discharge } \\
\text { measurements } \\
\text { of Fisk Pond } \\
\text { outlet at } \\
\text { State Highway 135 }\end{array}$ \\
\hline $10 / 31 / 77$ & 9.25 & 5.67 & 14.9 & 14.5 \\
$12 / 7 / 77$ & 20.3 & 11.0 & 31.3 & 31.1 \\
$4 / 20 / 78$ & 41.4 & 31.3 & 72.7 & 71.2 \\
$5 / 22 / 78$ & 10.1 & 6.25 & 16.4 & 17.5 \\
$6 / 19 / 78$ & 3.69 & 2.73 & 6.42 & 6.26 \\
$1 / 30 / 79$ & 58.3 & 23.7 & 82.0 & 86.2 \\
\hline
\end{tabular}


At all surface-water sampling sites, dissolved oxygen rarely dropped below $5.5 \mathrm{mg} / \mathrm{L}$. This is sufficient dissolved oxygen to convert nearly all the nitrite to nitrate. Due to the low concentrations of total nitrite nitrogen $(0.04 \mathrm{mg} / \mathrm{L}$ or less in all samples), it was added to the larger concentrations of total nitrate nitrogen and reported as the sum in all tables of concentrations and loads.

Total concentrations of the sums of various nitrogen and phosphorus species (ammonia and organic; nitrite and nitrate; ammonia, organic, nitrite, and nitrate; or thophosphate phosphorus; and phosphorus) were plotted versus instantaneous streamflow on logarithmic paper for all the gaging stations and Fisk Pond outlet to determine whether or not there are any relations between these nutrient species and instantaneous streamflow. Examination of the plots showed no relationships between instantaneous streamflow and the nitrogen species or orthophosphate phosphorus at these sites; however, relationships between instantaneous streamflow and total phosphorus were observed for Beaverdam, Course, and Pegan Brooks as well as Fisk Pond outlet, but not for Snake Brook or Lake Cochituate outlet.

Plots of streamflow versus the various nitrogen species and orthophosphate phosphorus shown in figure 3 for Beaverdam Brook are typical of all the sites.

For those sites where a relationship between total phosphorus and instantaneous streamflow was indicated by freehand curve fitting, a regression line (equation) was computed using a $\log$ transformation of the data and the method of least squares. The resultant equations show a direct relation at Beaverdam, Course, and Pegan Brooks, and an inverse relation at Fisk Pond outlet. These equations, along with their correlation coefficients and confidence limits at the 95 percent level (two-tailed test), are shown in table 3. The confidence limits shown in the table indicate that the slope of the regression equation is significantly different from zero at the 95 percent confidence limits.

Table 3.-Equations relating total phosphorus concentration to instantaneous streamflow for major surface-water sources

\begin{tabular}{|c|c|c|c|}
\hline $\begin{array}{c}\text { Equation } \\
\text { ( } \mathrm{P}=\text { Total phosphorus } \\
\text { concentration, in milligrams } \\
\text { per liter; } \mathrm{D}=\text { Instantaneous } \\
\text { streamflow, in cubic feet } \\
\text { per second })\end{array}$ & $\begin{array}{l}\text { Correlation } \\
\text { coefficient }\end{array}$ & $\begin{array}{l}\text { Ninety-five } \\
\text { percent } \\
\text { confidence } \\
\text { limits }\end{array}$ & $\begin{array}{l}\text { Range of } \\
\text { instantaneous } \\
\text { streamflow for } \\
\text { which these equations } \\
\text { are valid, in cubic } \\
\text { feet per second }\end{array}$ \\
\hline
\end{tabular}

Beaverdam Brook gaging station at Mill St., Natick
$\log P=-1.654401+0.279176 \log D \quad 0.58$
$0.279 \pm 0.174$
$1.1-214$
Course Brook gaging station at Pond St., Natick
$\log P=-1.956359+0.361278 \log D$
.72
$.361 \pm .156$
$2.4-180$
Pegan Brook gaging station at mouth, Natick
$\log P=-1.757255+0.709904 \log D$
.61
$.710 \pm .407$
$.23-16$

Fisk Pond outlet at State Highway 135, Natick
$\log P=-0.997125-0.324024 \log \mathrm{D}$
.71
$.324 \pm .142$
$3.5-86$ 


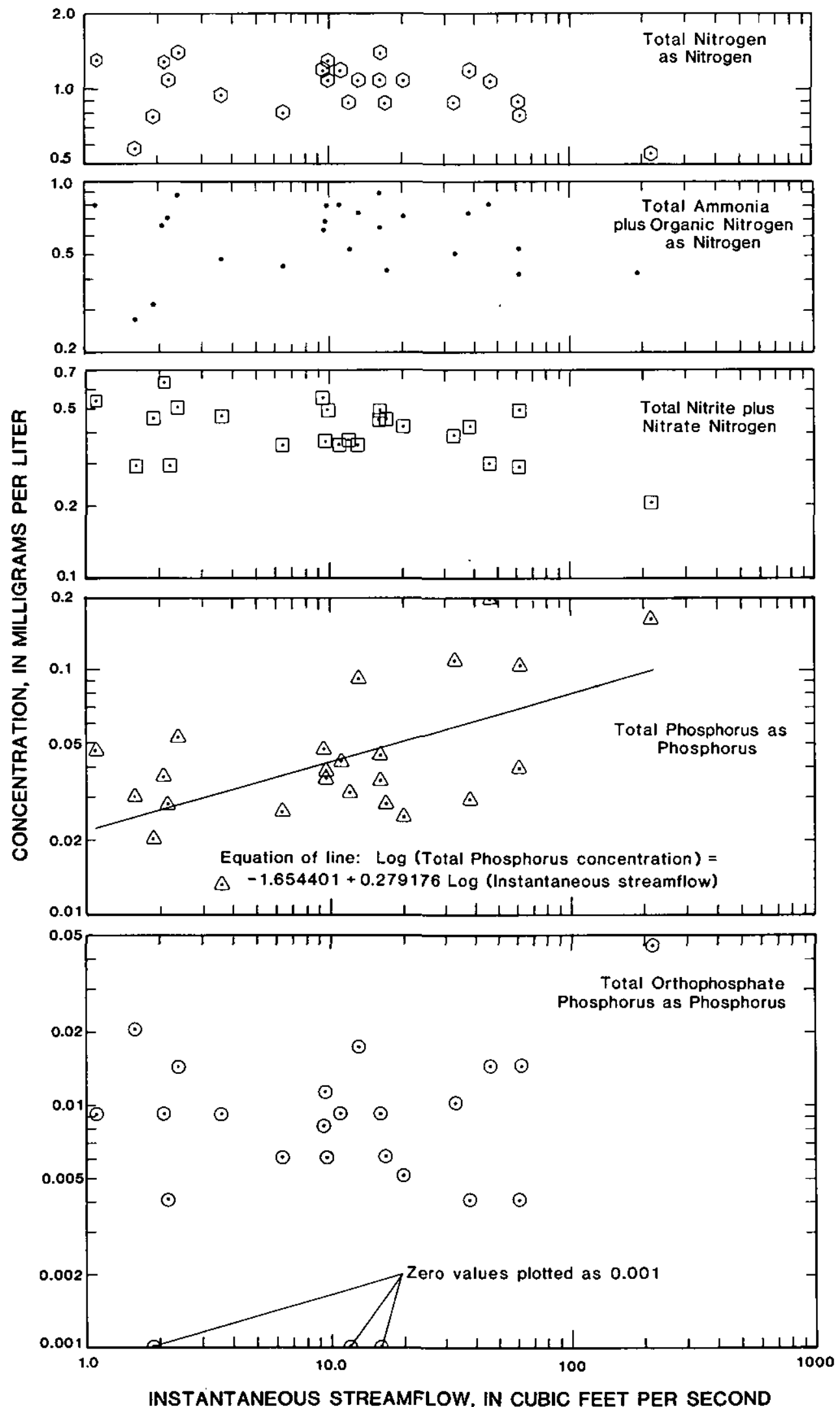

Figure 3.--Concentrations of selected nitrogen and phosphorus species as a function of instantaneous streamflow at Beaverdam Brook gaging station. 
The scatter of the data about the total phosphorus versus instantaneous streamflow regression line for Beaverdam Brook (fig. 3) is typical of the sites where either a direct or inverse relation was found. However, the slopes of the regression line for total phosphorus varies dramatically between sites. For example, at Beaverdam, Course, and Pegan Brooks about a 12-, 7-, and 3-fold increase in streamflow, respectively, is required to double the total phosphorus concentration, whereas at Fisk Pond outlet, an 8-fold decrease in streamflow is required to double the total phosphorus concentration.

Sylvester and Brown (1978) have shown that large and erratic variations in the concentration of total phosphorus in stream water can occur for the same discharge rate at different times during a storm and from storm to storm. Although regression lines for total phosphorus concentration versus instantaneous streamflow were derived for Beaverdam, Course, and Pegan Brooks as well as Fisk Pond outlet, the data pairs are few (24) and widely scattered, and the slopes of the regressions vary considerably from site to site. Because of the lack of any consistent trends in these relations, and the lack of any relation between the other nutrient species and instantaneous streamflow for these sites, the relations between total phosphorus concentration and instantaneous streamflow were not used in computing loads to or from Lake Cochituate. Instead, these equations were presented to show the possibility that there is a valid relationship betwen total phosphorus concentration and instantaneous streamflow; however, more data would be needed to verify these preliminary equations.

Accordingly, daily nutrient concentrations at each of the five gaging stations and Fisk Pond outlet were estimated by assuming that the nutrient concentrations in the monthly surface-water samples collected at each site represented the nutrient concentrations from half the time interval between any particular sample and the preceding sample to half the time interval between that particular sample and the succeeding sample. However, nutrient concentrations collected during runoff from three rainstorms were applied the day of the storm and two or more days thereafter depending on how long streamflow took to return to near pre-rain levels. The products of the daily concentration of each nutrient species, daily mean streamflow, and a conversion factor for pounds were summed to obtain the estimated monthly nutrient loads for the period November 1977 through May 1979, and annual nutrient loads for the period April 1978 through March 1979. Loads were computed for total ammonia nitrogen, total nitrite plus nitrate nitrogen, total organic nitrogen, total nitrogen, total or thophosphate phosphorus, and total phosphorus for surface-water sources discharging into Lake Cochituate and for lake-water discharging through Cochituate Brook.

Nutrient loads draining into Fisk Pond and Lake Cochituate from ungaged areas were estimated by multiplying the nutrient concentrations for Pegan Brook, the unit surfacewater runoff component from Pegan Brook, the ungaged drainage area, and a factor to convert to pounds.

Nutrient loads deposited directly onto Lake Cochituate by the December 8-9, 1978, and April 26-27, 1979, rainstorms were computed as the product of each storm's total rainfall, nutrient concentration, and the lake's surface area.

\section{Water Volumes of Ground Water}

Darcy's law (Ferris and others, 1962) was used to estimate the monthly quantities of ground-water inflow at various segments of shoreline around the lake where water-table measurements indicate ground water discharges to the lake. (See figure 4 for idealized diagram of ground-water flow system.) McBride and Pfannakuch (1975) have shown that where ground-water bodies beneath a lake are thin relative to the width of the lake, as is the case at Lake Cochituate, then ground-water discharge is concentrated within a short distance of the lake's shoreline and very little if any ground water flows beneath the lake to discharge elsewhere. 


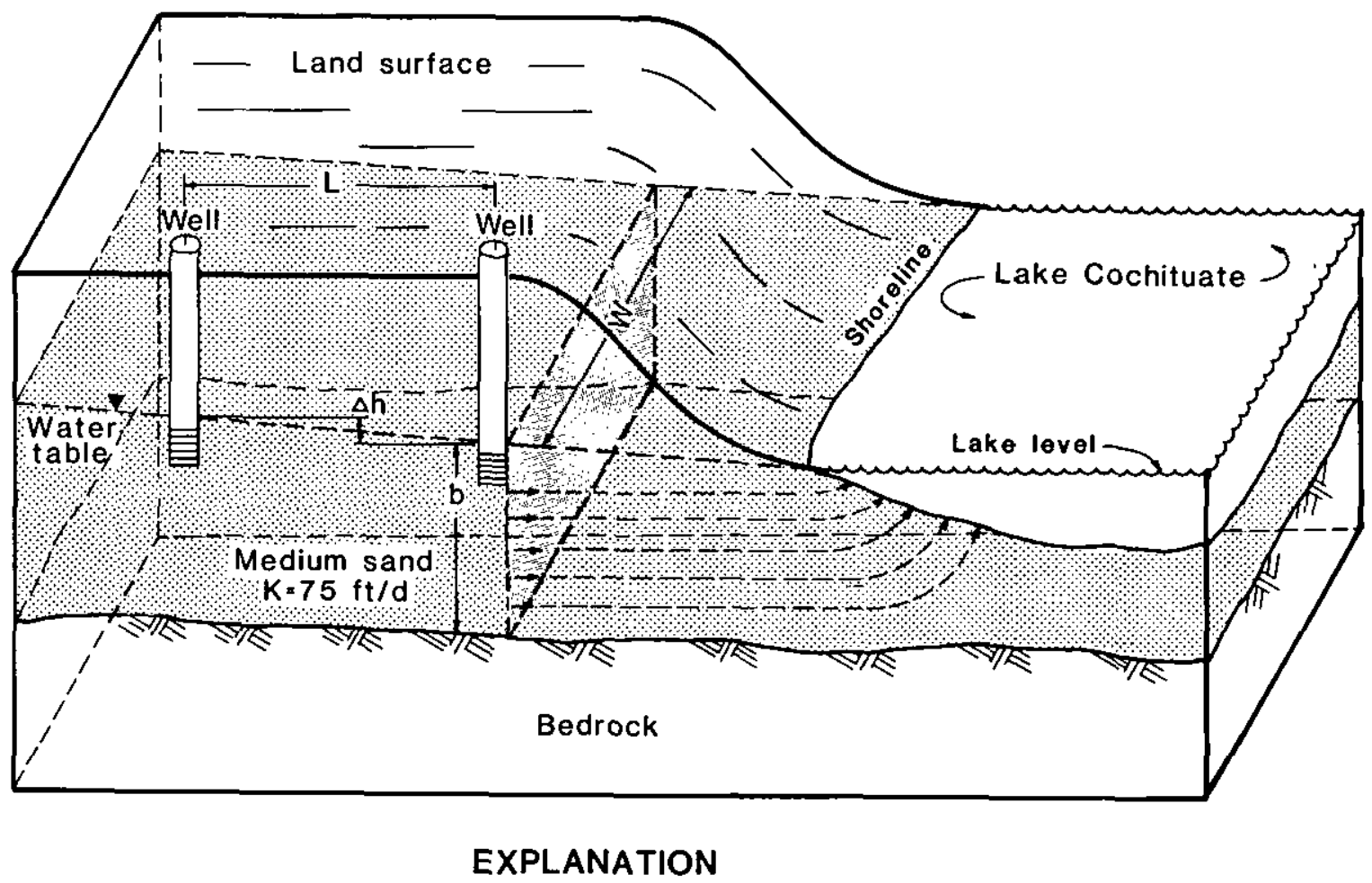

Equations
$Q=T I W$
where
$T=K b$
and
$I=\Delta h / L$

\section{Units}

$Q=$ Discharge, in cubic feet per day

$T=$ Transmissivity, in feet squared per day

$K=$ Hydraulic conductivity, in feet per day

$b=$ Saturated thickness of vertical section, in feet

$I=$ Hydraulic gradient, in feet per foot

$\Delta h=$ Difference in water levels between wells, in feet

$L=$ Distance between wells, in feet

$W=$ Width of imaginary vertical section, in feet

$\rightarrow$ Flowline

Imaginary vertical section

Figure 4.---ldealized ground-water flow system with equations for estimating discharge to Lake Cochituate from the adjacent unconsolidated deposits. 
Darcy's law $(Q=T I W)$ states that the quantity of water $(Q)$, in cubic feet per day, flowing through a vertical section of unconsolidated deposits near the shoreline is equal to the transmissivity $(T)$, in feet squared per day, multiplied by the hydraulic gradient (1), in feet per foot, and the width $(W)$, in feet, of the imaginary vertical section (fig. 4). To apply Darcy's law properly, the (1) hydraulic gradients have to be determined along the direction of ground-water flow (perpendicular to the water-table contours); (2) imaginary vertical section has to be perpendicular to the direction of ground-water flow; (3) flow of ground water is laminar and nearly horizontal; and (4) transmissivity and hydraulic gradients along the vertical section are uniform.

Darcy's law was modified to $Q=7.48$ NTIW to compute flows in gallons per month instead of cubic feet per day. The constant (7.48), converts cubic feet to gallons and the number of days $(\mathrm{N})$, converts days to any desired time frame such as a month.

Transmissivity is the rate at which water is transmitted through a unit width of aquifer material under a unit hydraulic gradient. It . was calculated by multiplying $\mathrm{K}$, the estimated hydraulic conductivity of the material, in feet per day, by $b$, the saturated thickness, in feet, of each lithologic unit overlying bedrock and summing the products. Lithologic logs of test holes drilled near the shoreline were used to estimate the hydraulic conductivities of the unconsolidated deposits by comparing the description of these materials to a list of saturated stratified materials of known hydraulic conductivities in table 4 (Brackley and Hansen, 1977).

Table 4.--Hydraulic conductivity of aquifer materials

\begin{tabular}{lc}
\hline Material & $\begin{array}{c}\text { Hydraulic } \\
\text { conductivity (K) } \\
\text { (feet per day) }\end{array}$ \\
\hline Gravel: & $300-700$ \\
Coarse & $200-300$ \\
Medium & $180-200$ \\
Fine & $150-400$ \\
Fine to coarse & \\
Sand: & 200 \\
and gravel & $90-150$ \\
Coarse & $70-80$ \\
Medium & $20-30$ \\
Fine & $40-150$ \\
Fine to coarse & $40-100$ \\
Fine to medium & less than 10 \\
Silt and clay &
\end{tabular}

At these sites, hydraulic gradients (I) were determined by dividing the difference in the monthly mean water levels between pairs of observation wells, one located near the shore and one located some distance upgradient, by the horizontal distance (L) between the wells. Monthly mean water levels for each observation well were determined by plotting graphs of monthly water-level measurements, connecting successive measurements with a straight line, and graphically determining a mean water level for each month or other desired time period. 


\section{Nutrient Loads in Ground Water}

Loads of total nitrogen and total phosphorus were computed for ground-water sources discharging directly to the lake without first discharging to a stream. These were calculated in a similar manner as nutrient loads from surface water. Because the concentrations of ammonia and organic nitrogen were much smaller than nitrate nitrogen and the orthophosphate phosphorus concentrations were similarily much smaller than total phosphorus, only total nitrogen and total phosphorus concentrations were used in computing nutrient loads. Average monthly concentrations of total nitrogen and phosphorus in ground water at various sites around the lake were estimated by assuming that the nutrient concentrations in ground-water samples collected from individual wells represented the nutrient concentrations from half the time interval between any particular sample and the preceding sample to half the time interval between that particular sample and the succeeding sample. Estimated monthly nutrient loads for July 1978 through June 1979 were calculated as the product of monthly ground-water discharge, average monthly nutrient concentration, and a conversion factor for pounds. When more than one sample for nutrient concentration was collected in a month, a ground-water discharge was computed for that period of the month representative of that sample. Each discharge was then multiplied by the appropriate nutrient concentration and a conversion factor, and then summed to obtain the estimated monthly nutrient load.

\section{SIGNIFICANCE OF NUTRIENT CONCENTRATIONS ON LAKE-WATER QUALITY}

Nitrogen compounds in water are generally considered to exist in two reduced forms and two oxidized forms. The reduced forms are the ammonium ion $\left(\mathrm{NH}_{4}^{+}\right)$and organic nitrogen which is nitrogen bound up in organic compounds such as plant and animal cellular material. All nitrogen that exists as ammonium ion or in equilibrium with ammonia $\left(\mathrm{NH}_{3}\right)$ is considered ammonia nitrogen. Oxidized forms of nitrogen are nitrite $\left(\mathrm{NO}_{2}^{-}\right)$and nitrate $\left(\mathrm{NO}_{3}^{-}\right)$ions. In a well-oxygenated environment, ammonium ion is rapidly converted by bacteria to nitrite ion which in turn is rapidly converted by a different bacteria to nitrate ion. Although organic nitrogen is bound in cellular material and not immediately available as a nutrient, a large part of organic nitrogen decomposes to ammonia and thereby becomes available.

There are many sets of standards and criteria for the concentrations of the various forms of nitrogen in natural waters. The USEPA (U.S. Environmental Protection Agency, 1975) specifies a maximum allowable concentration of total nitrate as nitrogen of $10 \mathrm{mg} / \mathrm{L}$ for public water supplies. On the other hand, the 1975 Annual Report of the CEQ (U.S. Council on Environmental Quality, 1975, p. 353) used a maximum total nitrate as nitrogen concentration of $0.6 \mathrm{mg} / \mathrm{L}$ as a "benchmark" level for "aquatic life protection," suggesting that higher levels are indicative of undesirable eutrophication. Many State water-quality standards specify a maximum of $10 \mathrm{mg} / \mathrm{L}$ of total nitrate as nitrogen, but several states have adopted more restrictive standards or criteria. In most cases, the restrictive standards represent an interest in controlling rates of eutrophication. For example, according to a summary by the USEPA (1971a), the criteria for Lake Michigan set by Illinios and Indiana state that total nitrogen should not exceed $0.4 \mathrm{mg} / \mathrm{L}$.

There are no generally accepted, uniform standards or criteria for maximum concentrations of phosphorus in natural waters. USEPA (1976) discusses a proposed criterion designed to prevent or control nuisance aquatic-plant growth. This criterion proposes that total phosphorus concentrations not exceed $0.05 \mathrm{mg} / \mathrm{L}$ for any stream at the point where it enters a lake or reservoir or not exceed $0.025 \mathrm{mg} / \mathrm{L}$ within the lake or reservoir. USEPA uses the term "total phosphates" which is equivalent to the use by the Survey of the term "total phosphorus." In a study of Wisconsin lakes, Sawyer (1947) concluded that $0.30 \mathrm{mg} / \mathrm{L}$ of inorganic nitrogen as nitrogen (sum of ammonia, nitrite, and nitrate) and $0.01 \mathrm{mg} / \mathrm{L}$ of orthophosphate phosphorus as phosphorus at the start of the growing season 
could produce nuisance blooms of algae. According to Wetzel (1975, p. 234),"...phosphorus is the least abundant element of the major nutrients required for algal growth in a majority of fresh waters. Furthermore, the most important form of phosphorus for plant nutrition is ionized inorganic phosphate" (or thophosphate phosphorus). However, Wetzel (1975, p. 216) concludes, "...the most important quantity, in view of the metabolic characteristics within a lake, is the total phosphorus content of unfiltered water." Chemical and biochemical reactions occurring within the lake are capable of transforming the various states of phosphorus into or thophosphate phosphorus. The more nitrogen, and in particular phosphorus, added to the lake, the more productive the lake will become assuming other necessary micronutrients such as molybdenum, zinc, or cobalt are not already growth limiting. However, Wetzel (1975, p. 640-644) points to a number of case studies which show that of these two nutrients (nitrogen and phosphorus), phosphorus, rather than nitrogen, in the majority of the cases increases lake eutrophocation levels when added to a water body and decreases eutrophication levels when withdrawn. Therefore, if the level of biological productivity in the lake is above what is desired and nitrogen is not the limiting nutrient, the phosphorus input to and content of the lake waters has to be lowered before productivity can be lowered.

Another approach that can be used to determine whether or not the phosphorus concentrations in water entering a lake will cause undesirable aquatic-plant growth within a lake is to examine the annual phosphorus loading to the lake. Certain factors, such as surface area of the lake, depth, and amount of water entering the lake, affect the amount of phosphorus loading that a lake may receive and yet still maintain a phosphorus level which will not cause excessive aquatic growth. After assessing euthrophication data from numerous lakes, Vollenweider developed the following equation (as expressed in Hammer and Mac Kichan, 1981):

$$
P=\frac{L / q}{1+(z / q) 0.5}
$$

where

$$
\begin{aligned}
& P=\text { Phosphorus concentration in lake water, in grams per cubic meter (grams } \\
& \text { per cubic meter is equivalent to milligrams per liter); } \\
& L=\begin{array}{c}
\text { annual phosphorus loading, in grams per square meter of lake surface per } \\
\text { year; }
\end{array} \\
& q=\text { annual hydraulic loading, in meters (cubic meters of water per square } \\
& \text { meters of lake surface) per year or mean depth/retention time }(z / t) ; \\
& z=\text { mean depth, in meters. }
\end{aligned}
$$

To convert the data used in this equation from inch-pound units to the International System of units (metric), refer to the "Conversion Table" on page vi of this report.

Hammer and Mac Kichan (1981) reports (p. 411) that the commonly accepted critical phophorus concentration in lake water is $0.01 \mathrm{mg} / \mathrm{L}$ at the end of the spring overturn. At this level or lower, lakes usually have no excessive algal-plant growth during the growing season. However, observed phosphorus concentrations in lake water greater than $0.02 \mathrm{mg} / \mathrm{L}$ at the spring overturn are likely to produce excessive aquatic-plant growth creating eutrophic conditions. 


\section{Water Balance}

Water enters Lake Cochituate from: (1) Precipitation on the lake surface; (2) overland runoff from the surrounding land surface by way of ponds, streams, storm sewers, and ditches; and (3) ground-water discharge. Water leaves Lake Cochituate through: (1) Evaporation; (2) flow into Cochituate Brook at the lake's outlet; (3) seepage into the unconsolidated materials adjacent to the lake owing to artificial hydraulic gradients caused by pumping municipal-supply wells and to natural hydraulic gradients caused by the difference in water levels between the lake and the Sudbury River; and (4) leakage into the Cochituate Aqueduct. The intake structure that allowed lake water to flow into the Cochituate Aqueduct has been closed and the aqueduct removed from service by the MDC. Leakage of lake water and seepage of ground water from the unconsolidated deposits into that portion of the aqueduct near the lake is minor (Carlton L. Noyes of Jason M. Cortell and Associates, Inc., personal commun., 1978) and was considered to have no effect on the water balance in this study.

Each of the processes by which water enters and leaves Lake Cochituate is an important component of the hydrologic system of the lake. Together, the components comprise a hydrologic budget, or water balance, that describes the inflow and outflow of lake water. The equation which describes this water balance of the lake is as follows:

$$
\Delta S=P+S W_{i}+G W_{i}-E-L W_{c b}-L W_{s p}-L W_{S}
$$

where

$$
\begin{array}{ll}
\Delta S & =\text { Change in lake-volume storage; } \\
P & =\text { precipitation on the lake surface; } \\
S W_{i} \quad & =\text { surface-water inflow; } \\
G W_{i} & =\text { ground-water inflow; } \\
E & =\text { evaporation from the lake surface; } \\
L W_{c b} & =\text { lake-water outflow into Cochituate Brook; } \\
L W_{S p} & =\text { lake-water seepage into the unconsolidated deposits induced by } \\
L W_{S} & =\text { large-capacity pumping wells; }
\end{array}
$$

The variables in the above equation have associated measurement errors which differ markedly because some hydrologic parameters are more easily and accurately measured than others. For example, Winter (1981, p. 109, table 7) shows calculated total errors for common methodologies used to compute various components of the annual water balance in New England lakes. These errors are +17 percent for precipitation, \pm 23 percent for streamflow into the lake, \pm 12 percent for lake-water outflow at the surface outlet, \pm 23 percent for evaporation, and unknown errors for ground-water inflow and outflow. 


\section{Nutrient Balance}

Each component of the water balance except evaporation transports a quantity of nitrogen and phosphorus. A general nutrient inflow and outflow summary of Lake Cochituate can be estimated by multiplying each component on the right side of the above water balance by the nutrient concentration it transports. In this report, all nutrient loads are reported to the nearest two significant figures because the concentrations of the various nitrogen species are only reported to the nearest two significant figures.

Although this type of generalized inflow/outflow summary is not a complete nutrient budget for the lake, the estimates of nutrient loads are particularly useful in determining the relative magnitudes of the various nutrient sources to the lake. Additional data on nutrient sources and sinks within the lake would have to be quantified and included before a complete nutrient budget for the lake could be estimated. Examples of the additional data that would be needed are: (1) Nitrogen and phosphorus in the lakewater column that was lost to or released from the lake-bottom sediments; (2) nitrogen fixed from the atmosphere by the algae in the lake water; and (3) denitrification from the lake-water column.

\section{ESTIMATED WATER AND NUTRIENT INFLOWS TO LAKE COCHITUATE FROM SELECTED SOURCES}

The following discussion on water and nutrient inflows as well as a later discussion on water and nutrient outflows are presented by hydrologic component in the order of decreasing nutrient loads.

\section{Surface Water}

Water Volumes

Analysis of the streamflow data shows (table 5) that 75 percent of the surfacewater flow into Lake Cochituate for the period November 1977 through May 1979 was from Beaverdam and Course Brooks. Streamflow into Fisk Pond from Beaverdam and Course Brooks gaging stations contribute 47 and 26 percent, respectively. The remaining surface-water sources that contribute water directly to the lake are: Snake Brook, 13 percent; ungaged land area draining into Lake Cochituate, 8 percent; and Pegan Brook, 4 percent.

Evapotranspiration during the spring, summer, and early fall consumes more water than during the remainder of the year, and this consumption has a pronounced effect on lowering surface-water discharge to the lake. For example, only 32 percent of the total surface-water runoff for the period April 1978 through March 1979 entered the lake between April and October, whereas 68 percent entered from November through March. In addition, streamflow from Beaverdam and Course Brooks through Fisk Pond provided nearly all the surface-water inflow to the lake during the summer and fall (fig. 5).

\section{Nutrient Concentrations in Major Surface-Water Sources}

The instream nutrient concentration data (table 6) shows that Pegan and Snake Brooks have the highest average concentration of total nitrogen. Nearly all sites have nearly the same average total phosphorus concentration, except Course Brook which has about half as much. Possible nutrient sources include decaying leaves, lawn fertilizers, septic tanks, domestic-animal wastes, and pollution from automobiles.

Total concentrations of the sums of various nitrogen and phosphorus species (ammonia and organic; nitrite and nitrate; ammonia, organic, nitrite, and nitrate; orthophosphate phosphorus, and phosphorus) were plotted versus time on arithmetic paper for all the gaging stations and Fisk Pond outlet to determine if there were any seasonal relationships. Total nitrite plus nitrate concentrations at Lake Cochituate outlet was the only definitive seasonal relationship detected throughout the 19-month period by this approach. 
Table 5.-Monthly runoff entering Fisk Pond and Lake Cochituate from surface-water sources and precipitation

\begin{tabular}{|c|c|c|c|c|c|c|c|c|c|c|}
\hline \multirow{2}{*}{$\begin{array}{l}\text { Name of } \\
\text { drainage area }\end{array}$} & \multirow{2}{*}{$\begin{array}{l}\text { Drainage } \\
\text { area } \\
\text { (square } \\
\text { miles) }\end{array}$} & \multicolumn{2}{|c|}{1977} & \multicolumn{7}{|c|}{1978} \\
\hline & & Nov. & Dec. & Jan. & Feb. & Mar. & April & May & June & July \\
\hline $\begin{array}{l}\text { Beaverdam Brook } \\
\text { at gaging station }\end{array}$ & 7.25 & 377.3 & 642.1 & 899.0 & 209.3 & 615.6 & 393.6 & 299.0 & 103.4 & 60.9 \\
\hline $\begin{array}{l}\text { Course Brook at } \\
\text { gaging station }\end{array}$ & 3.42 & 164.1 & 291.2 & 372.9 & $99.1^{\circ}$ & 382.8 & 187.5 & 164.3 & 65.0 & 48.6 \\
\hline $\begin{array}{l}\text { Estimated flow from } \\
\text { ungaged area drain- } \\
\text { ing into Fisk Pond }\end{array}$ & ${ }^{1} .75$ & 18.8 & 30.1 & 45.5 & 1.1 & 35.7 & 9.3 & 9.8 & 2.1 & 5.5 \\
\hline $\begin{array}{l}\text { Estimated flow from } \\
\text { Fisk Pond outlet }\end{array}$ & 11.4 & 560.2 & 963.4 & 1317.4 & 309.5 & 1034.1 & 590.4 & 473.1 & 170.5 & 115.0 \\
\hline $\begin{array}{l}\text { Pegan Brook at } \\
\text { gaging station }\end{array}$ & .54 & 29.9 & 45.3 & 57.1 & 19.0 & 46.0 & 27.2 & 21.9 & 12.1 & 11.1 \\
\hline $\begin{array}{l}\text { Snake Brook at } \\
\text { gaging station }\end{array}$ & 2.10 & 96.8 & 160.1 & 216.7 & 66.8 & 167.9 & 129.8 & 77.1 & 25.6 & 9.6 \\
\hline $\begin{array}{l}\text { Estimated overland } \\
\text { runoff from ungaged } \\
\text { land area draining } \\
\text { directly into } \\
\text { Lake Cochituate }\end{array}$ & 2.70 & 67.5 & 108.2 & 163.9 & 3.9 & 128.5 & 33.3 & 35.4 & 7.6 & 19.6 \\
\hline $\begin{array}{l}\text { Total runoff entering } \\
\text { Lake Cochituate } \\
\text { from surface-water } \\
\text { sources }\end{array}$ & 16.8 & 754.4 & 1277.0 & 1755.1 & 399.2 & 1376.5 & 780.7 & 607.5 & 215.8 & 155.3 \\
\hline $\begin{array}{l}\text { Precipitation onto } \\
\text { surface of Lake } \\
\text { Cochituate }\end{array}$ & .92 & 60.3 & 98.5 & 137.7 & 36.9 & 43.8 & 26.2 & 59.2 & 18.7 & 41.3 \\
\hline \multirow{3}{*}{$\begin{array}{c}\text { Name of } \\
\text { drainage area }\end{array}$} & \multicolumn{9}{|c|}{ Runoff, in million gallons } & \\
\hline & \multicolumn{5}{|c|}{1978} & \multicolumn{5}{|c|}{1979} \\
\hline & Aug. & Sept. & Oct. & Nov. & Dec. & Jan. & Feb. & Mar. & April & May \\
\hline $\begin{array}{l}\text { Beaverdam Brook } \\
\text { at gaging station }\end{array}$ & 117.2 & 38.8 & 68.7 & 67.2 & 204.3 & 1096.1 & 262.8 & 492.5 & 406.5 & 349.0 \\
\hline $\begin{array}{l}\text { Course Brook at } \\
\text { gaging station }\end{array}$ & 70.0 & 52.0 & 59.8 & 53.8 & 86.3 & 690.9 & 169.1 & 296.3 & 213.9 & 185.5 \\
\hline $\begin{array}{l}\text { Estimated flow from } \\
\text { ungaged area drain- } \\
\text { ing into Fisk Pond }\end{array}$ & 14.0 & 2.9 & 6.2 & 3.6 & 8.7 & 109.4 & 9.2 & 9.9 & 14.5 & 13.5 \\
\hline $\begin{array}{l}\text { Estimated flow from } \\
\text { Fisk Pond outlet }\end{array}$ & 201.2 & 93.7 & 134.7 & 124.6 & 299.3 & 1896.4 & 441.1 & 798.7 & 634.9 & 548.0 \\
\hline $\begin{array}{l}\text { Pegan Brook at } \\
\text { gaging station }\end{array}$ & 17.7 & 5.9 & 8.8 & 5.5 & 11.5 & 96.2 & 21.2 & 30.5 & 27.3 & 22.9 \\
\hline $\begin{array}{l}\text { Snake Brook at } \\
\text { gaging station }\end{array}$ & 18.5 & 4.9 & 10.0 & 12.9 & 45.6 & 362.2 & 84.3 & 141.0 & 110.0 & 97.3 \\
\hline $\begin{array}{l}\text { Estimated overland } \\
\text { runoff from ungaged } \\
\text { land area draining } \\
\text { directly into } \\
\text { Lake Cochituate }\end{array}$ & 50.5 & 10.6 & 22.3 & 13.1 & 31.3 & 393.8 & 33.0 & 35.6 & 52.3 & 48.6 \\
\hline $\begin{array}{l}\text { Total runoff entering } \\
\text { Lake Cochituate } \\
\text { from surface-water } \\
\text { sources }\end{array}$ & 287.9 & 115.1 & 175.8 & 156.1 & 387.7 & 2748.6 & 579.6 & 1005.8 & 824.5 & 716.8 \\
\hline $\begin{array}{l}\text { Precipitation onto } \\
\text { surface of Lake } \\
\text { Cochituate }\end{array}$ & 91.1 & 24.1 & 55.2 & 45.9 & 60.3 & 207.4 & 44.9 & 46.7 & 74.7 & 78.0 \\
\hline
\end{tabular}

${ }^{1}$ Includes area of Fisk Pond. 


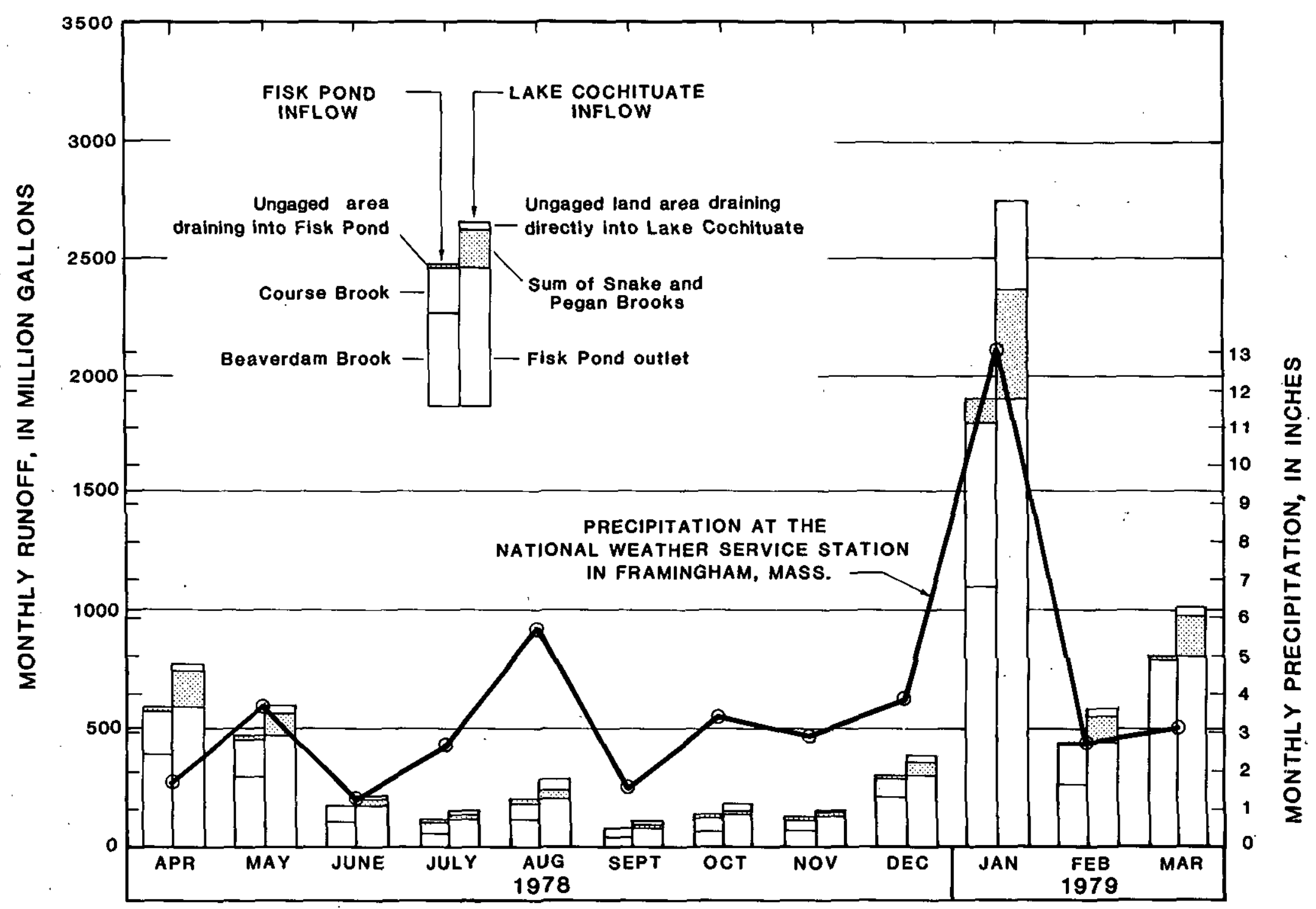

Figure 5.--Monthly runoff entering Fisk Pond and Lake Cochituate from surface-water sources for the period April 1978 through March 1979. 
Table 6.--Maximum, average, and minimum concentrations of nutrient species entering Fisk Pond and Lake Cochituate from

major surface-water sources

(Data collected from July 29, 1977, through May 3, 1979)

\begin{tabular}{|c|c|c|c|c|c|c|c|}
\hline \multirow[b]{2}{*}{$\begin{array}{l}\text { Station } \\
\text { name }\end{array}$} & \multirow[b]{2}{*}{$\begin{array}{r}\text { Type of } \\
\text { statistic }\end{array}$} & \multicolumn{6}{|c|}{ Concentration, in milligrams per liter } \\
\hline & & $\begin{array}{l}\text { Total } \\
\text { am monia } \\
\text { nitrogen } \\
\text { (as ni- } \\
\text { trogen) }\end{array}$ & $\begin{array}{l}\text { Total } \\
\text { nitrite } \\
\text { plus } \\
\text { nitrate } \\
\text { nitrogen } \\
\text { (as ni- } \\
\text { trogen) }\end{array}$ & $\begin{array}{l}\text { Total } \\
\text { organic } \\
\text { nitrogen } \\
\text { (as ni- } \\
\text { trogen) }\end{array}$ & $\begin{array}{l}\text { Total } \\
\text { nitrogen } \\
\text { (as ni- } \\
\text { trogen) }\end{array}$ & $\begin{array}{l}\text { Total } \\
\text { or tho- } \\
\text { phosphate } \\
\text { phos- } \\
\text { phorus } \\
\text { (as phos- } \\
\text { phorus) }\end{array}$ & $\begin{array}{l}\text { Total } \\
\text { phos- } \\
\text { phorus } \\
\text { (as } \\
\text { phos- } \\
\text { phorus) }\end{array}$ \\
\hline \multirow{5}{*}{$\begin{array}{l}\text { Beaverdam } \\
\text { Brook gaging } \\
\text { station at } \\
\text { Mill St., } \\
\text { Natick }\end{array}$} & Maximum & 0.29 & 0.64 & 0.88 & 1.4 & 0.044 & 0.193 \\
\hline & Average & .11 & .41 & .52 & 1.0 & .010 & .054 \\
\hline & Minimum & .00 & .20 & .18 & .57 & .000 & .013 \\
\hline & No. of & & & & & & \\
\hline & analyses & 24 & 24 & 24 & 24 & 24 & 24 \\
\hline \multirow{5}{*}{$\begin{array}{l}\text { Course Brook } \\
\text { gaging } \\
\text { station at } \\
\text { Pond St., } \\
\text { Natick }\end{array}$} & Maximum & .17 & .48 & .69 & 1.0 & .036 & .070 \\
\hline & Average & .04 & .26 & .36 & .65 & .007 & .025 \\
\hline & Minimum & .00 & .09 & .10 & .38 & .000 & .009 \\
\hline & No. of & & & & & & \\
\hline & analyses & 24 & 24 & 24 & 24 & 24 & 24 \\
\hline \multirow{5}{*}{$\begin{array}{l}\text { Fisk Pond } \\
\text { outlet at } \\
\text { State } \\
\text { Highway } 135 \text {, } \\
\text { Natick }\end{array}$} & Maximum & .68 & .50 & 2.3 & 3.0 & .025 & .140 \\
\hline & Average & .10 & .21 & .62 & .93 & .006 & .051 \\
\hline & Minimum & .00 & .00 & .25 & .52 & .000 & .019 \\
\hline & No. of & & & & & & \\
\hline & analyses & 22 & 22 & 22 & 22 & 22 & 22 \\
\hline \multirow{5}{*}{$\begin{array}{l}\text { Pegan Brook } \\
\text { gaging } \\
\text { station } \\
\text { at mouth, } \\
\text { Natick }\end{array}$} & Maximum & .11 & 2.5 & 1.4 & 2.9 & .033 & .261 \\
\hline & Average & .05 & 1.5 & .36 & 1.9 & .006 & .040 \\
\hline & Minimum & .00 & .29 & .00 & .53 & .000 & .001 \\
\hline & No. of & & & & & & \\
\hline & analyses & 24 & 24 & 24 & 24 & 24 & 24 \\
\hline \multirow{5}{*}{$\begin{array}{l}\text { Snake Brook } \\
\text { gaging } \\
\text { station at } \\
\text { State Highway } \\
27 \text {, Wayland }\end{array}$} & Maximum & .17 & 1.9 & .77 & 2.8 & .037 & .139 \\
\hline & Average & .05 & 1.0 & .40 & 1.5 & .005 & .037 \\
\hline & Minimum & .00 & .28 & .06 & .72 & .000 & .008 \\
\hline & No. of & & & & & & \\
\hline & analyses & 24 & 24 & 24 & 24 & 24 & 24 \\
\hline
\end{tabular}

Analysis of average concentrations of various nitrogen and phosphorus species for these sites indicate that some of the streams contribute nutrient concentrations in excess of the various standards described in the section on "Significance of nutrient concentrations on lake-water quality".

Average total nitrogen concentrations are in excess of the $0.4 \mathrm{mg} / \mathrm{L}$ criteria for Lake Michigan. The same is true for other species of nitrogen. Average total nitrate as nitrogen concentration in Pegan and Snake Brooks (table 6) exceeds the CEQ "benchmark" level of $0.6 \mathrm{mg} / \mathrm{L}$ for that constituent. This standard is exceeded even after a maximum concentration of $0.04 \mathrm{mg} / \mathrm{L}$ is subtracted from the average total nitrate nitrogen concentration to remove the nitrite fraction. 
The average total phosphorus as phosphorus concentration for Fisk Pond outlet is at the USEPA's criterion of $0.05 \mathrm{mg} / \mathrm{L}$ for any stream at the point where it enters a lake or reservoir, yet the average total phosphorus as phosphorus concentrations for Pegan and Snake Brooks are below this criteria (table 6). However, 75 percent of the streamflow entering Lake Cochituate is from Fisk Pond making it the largest single contributor of surface water and nutrients to the lake.

\section{Nutrient Concentrations in Storm Sewers}

Concentrations of selected nutrients were determined from samples collected from storm sewers (pl. 1) during three separate overland-runoff events generated by the December 8 and 9, 1978, January 24-26 and April 26 and 27, 1979, rainstorms. The December storm occurred after most of the leaves had fallen to the ground. The intense storm in January deposited about 4 inches of rainfall at the National Weather Service Station in Framingham and was the last in a series of rainstorms that passed over the Lake Cochituate basin that month. The April storm occurred in early spring probably after some of the leaves had been raked and the lawns fertilized.

The nutrient concentration data collected from these overland runoff events can be used to estimate the (1) probable range and average nutrient concentrations for each storm for the sampled storm sewers (table 7); and (2) probable range in nutrient concentrations for each storm sewer (table 8). However, the nutrient concentration and flow data were insufficient to allow for an accurate estimate of nutrient loads from individual storm sewers to the lake.

Table 8 shows that the concentrations of the various nutrients in storm-sewer discharge varies considerably at each site as well as between sites. Some possible causes for the observed variations are: (1) First-flush effect; (2) time interval between storms and street cleanings; (3) seasonal variation in the accumulation of pollutants on the land area; (4) land-use and land-cover characteristics; (5) slope of the basin; (6) leaching rates (solubilities) of substances present in the urban environment; (7) amount of within-basin storage; (8) percent impervious area; (9) chemistry of precipitation; and (10) rainfall characteristics (depth, intensity, duration, and distribution). For example, varying rainfall intensities during a storm has a pronounced affect on washing pollutants from the land surface. This phenomenon is demonstrated when comparing two sets of nutrient concentrations and instantaneous discharges collected from two storm sewers for the April 2627, 1979, rainfall event (table 9). A substantial change in total phosphorus concentrations at each storm-sewer outfall was observed after a heavy downpour increased storm-water discharge just prior to the latter sample. Generally, suspended-sediment concentration increases with rapid increases in discharge. This downpour washed soil (sediment) particles which probably contained sorbed phosphorus into the storm sewers. According to Alley (1977, p. 82), phosphorus remains sorbed to soil particles during transport. Therefore, the high concentrations of total phosphorus in the latter samples are probably related to the suspended-sediment concentration which from visual inspection was higher during the latter samples.

Analysis of the nutrient data collected at the storm sewers indicates that the average total nitrogen concentration of $0.63 \mathrm{mg} / \mathrm{L}$ for all storm-sewer samples is about one-third lower than the average total nitrogen concentration of $0.93 \mathrm{mg} / \mathrm{L}$ for Fisk Pond outlet (table 6). However, both the average total orthophosphate phosphorus concentration, $0.061 \mathrm{mg} / \mathrm{L}$, and the average total phosphorus concentrations, $0.147 \mathrm{mg} / \mathrm{L}$, for all storm-sewers are about 10 and 3 times higher, respectively, than comparative average values for Fisk Pond outlet of 0.006 and $0.051 \mathrm{mg} / \mathrm{L}$, respectively. The higher phosphorus values for storm-sewer samples could be related to the higher suspended-sediment concentration in storm-water discharge. Fisk Pond acts as a detention basin by slowing the velocity of water moving through the pond and allowing the large denser suspendedsediment particles to settle out of suspension. 
Table 7.-Maximum, average, and minimum concentrations of nutrient species entering Fisk Pond and Lake Cochituate from representative storm sewers and major surface-water sources

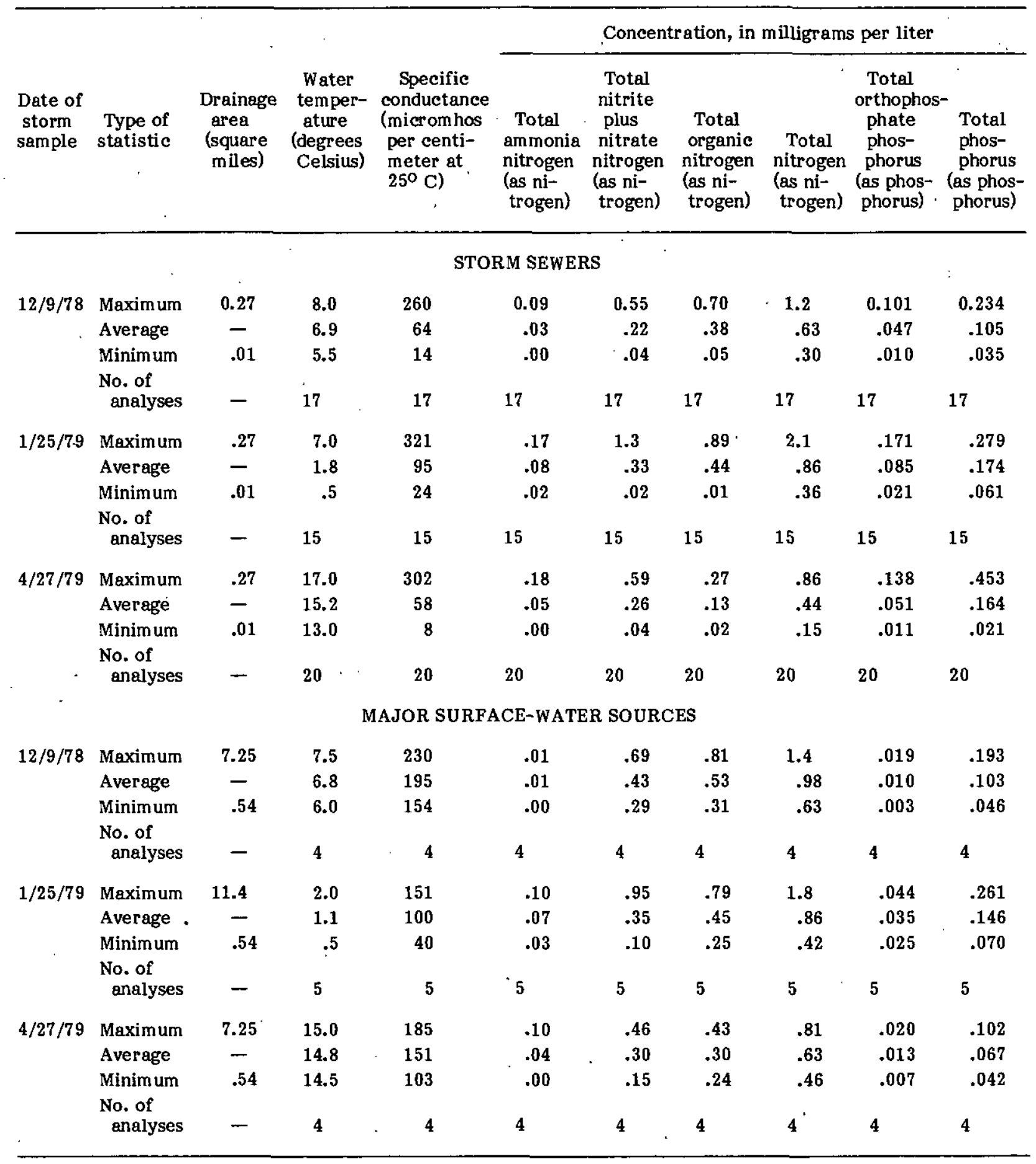


Table 8.-Maximum and minimum concentrations of nutrient species entering Fisk Pond and Lake Cochituate from representative storm sewers and major surface-water sources

\begin{tabular}{|c|c|c|c|c|c|c|c|c|c|c|}
\hline \multirow[b]{2}{*}{$\begin{array}{l}\text { Station name } \\
\text { and location } \\
\text { (Number on plate 1; } \\
\text { identical number } \\
\text { given to station on } \\
\text { plate } 1 \text { in Gay, 1981) }\end{array}$} & \multirow[b]{2}{*}{$\begin{array}{l}\text { Drainage } \\
\text { area } \\
\text { (square } \\
\text { miles) }\end{array}$} & \multirow[b]{2}{*}{$\begin{array}{l}\text { Type of } \\
\text { statistic }\end{array}$} & \multirow[b]{2}{*}{$\begin{array}{l}\text { Instanta- } \\
\text { neous } \\
\text { discharge } \\
\text { (cubic feet } \\
\text { per second) }\end{array}$} & \multirow[b]{2}{*}{$\begin{array}{l}\text { Specific } \\
\text { conductance } \\
\text { (micromhos } \\
\text { per centi- } \\
\text { meter at } \\
25^{\circ} \mathrm{C} \text { ) }\end{array}$} & \multicolumn{6}{|c|}{ Concentration, in milligrams per liter } \\
\hline & & & & & $\begin{array}{l}\text { Total } \\
\text { ammonia } \\
\text { nitrogen } \\
\text { (as ni- } \\
\text { trogen) }\end{array}$ & $\begin{array}{l}\text { Total ni- } \\
\text { trite plus } \\
\text { nitrate } \\
\text { nitrogen } \\
\text { (as ni- } \\
\text { trogen) }\end{array}$ & $\begin{array}{l}\text { Total } \\
\text { organic } \\
\text { nitrogen } \\
\text { (as ni- } \\
\text { trogen) }\end{array}$ & $\begin{array}{l}\text { Total } \\
\text { nitrogen } \\
\text { (as ni- } \\
\text { trogen) }\end{array}$ & $\begin{array}{l}\text { Total } \\
\text { ortho- } \\
\text { phosphate } \\
\text { phosphorus } \\
\text { (as phos- } \\
\text { phorus) }\end{array}$ & $\begin{array}{l}\text { Total } \\
\text { phos- } \\
\text { phorus } \\
\text { (as phos- } \\
\text { pirorus) }\end{array}$ \\
\hline \multicolumn{11}{|c|}{ STORM SEWERS } \\
\hline $\begin{array}{l}\text { Storm-sewer outfall } \\
\text { at Superior Dr., } \\
\text { Natick (2) }\end{array}$ & - & $\begin{array}{c}\text { Maximum } \\
\text { Minimum } \\
\text { No. of analyses }\end{array}$ & $\begin{array}{l}0.42 \\
.29 \\
3\end{array}$ & $\begin{array}{r}233 \\
19 \\
3\end{array}$ & $\begin{array}{c}0.11 \\
.04 \\
3\end{array}$ & $\begin{array}{l}0.54 \\
.26 \\
3\end{array}$ & $\begin{array}{c}0.08 \\
.01 \\
3\end{array}$ & $\begin{array}{l}0.59 \\
.41 \\
3\end{array}$ & $\begin{array}{l}0.037 \\
.011 \\
3\end{array}$ & $\begin{array}{l}0.116 \\
.021 \\
3\end{array}$ \\
\hline $\begin{array}{l}\text { Storm-sewer outfall ' } \\
\text { near Robinhood Rd., } \\
\text { Natick (3) }\end{array}$ & 0.01 & $\begin{array}{c}\text { Maximum } \\
\text { Minimum } \\
\text { No. of analyses }\end{array}$ & $\begin{array}{l}.19 \\
.12 \\
2\end{array}$ & $\begin{array}{c}14 \\
9 \\
2\end{array}$ & $\begin{array}{l}.02 \\
.01 \\
2\end{array}$ & $\begin{array}{l}.12 \\
.09 \\
2\end{array}$ & $\begin{array}{l}.18 \\
.12 \\
2\end{array}$ & $\begin{array}{l}.31 \\
.23 \\
2\end{array}$ & $\begin{array}{l}.084 \\
.070 \\
2\end{array}$ & $\begin{array}{l}.258 \\
.107 \\
2\end{array}$ \\
\hline $\begin{array}{l}\text { Storm-sewer outfall } \\
\text { at Possurn Hollow Ln., } \\
\text { Natick (4) }\end{array}$ & .05 & $\begin{array}{c}\text { Maximum } \\
\text { Minimum } \\
\text { No. of analyses }\end{array}$ & $\begin{array}{l}.67 \\
.04 \\
4\end{array}$ & $\begin{array}{r}117 \\
32 \\
4\end{array}$ & $\begin{array}{l}.10 \\
.01 \\
4\end{array}$ & $\begin{array}{l}.59 \\
.21 \\
4\end{array}$ & $\begin{array}{l}.43 \\
.16 \\
4\end{array}$ & $\begin{array}{l}.85 \\
.51 \\
4\end{array}$ & $\begin{array}{l}.082 \\
.029 \\
4\end{array}$ & $\begin{array}{l}.165 \\
.054 \\
4\end{array}$ \\
\hline $\begin{array}{l}\text { Storm-sewer outfall } \\
\text { at Crescent St., } \\
\text { Natick (5) }\end{array}$ & .03 & $\begin{array}{c}\text { Maximum } \\
\text { Minimum } \\
\text { No. of analyses }\end{array}$ & $\begin{array}{l}1.4 \\
.01 \\
4\end{array}$ & $\begin{array}{r}86 \\
25 \\
4\end{array}$ & $\begin{array}{l}.02 \\
.00 \\
4\end{array}$ & $\begin{array}{l}.52 \\
.09 \\
4\end{array}$ & $\begin{array}{l}.89 \\
.22 \\
4\end{array}$ & $\begin{array}{l}1.1 \\
.31 \\
4\end{array}$ & $\begin{array}{l}.054 \\
.023 \\
4\end{array}$ & $\begin{array}{l}.453 \\
.082 \\
4\end{array}$ \\
\hline $\begin{array}{l}\text { Set tling Basin Pond } \\
\text { at outlet, } \\
\text { Natick (6) }\end{array}$ & .15 & $\begin{array}{c}\text { Maximum } \\
\text { Minimum } \\
\text { No. of analyses }\end{array}$ & $\begin{array}{c}2.2 \\
1.7 \\
3\end{array}$ & $\begin{array}{l}260 \\
116 \\
3\end{array}$ & $\begin{array}{l}.09 \\
.01\end{array}$ & $\begin{array}{l}.48 \\
.21 \\
3\end{array}$ & $\begin{array}{l}.70 \\
.15 \\
3\end{array}$ & $\begin{array}{l}1.2 \\
.37 \\
3\end{array}$ & $\begin{array}{l}.050 \\
.019 \\
3\end{array}$ & $\begin{array}{l}.152 \\
.131 \\
3\end{array}$ \\
\hline $\begin{array}{l}\text { Storm-sewer outfall } \\
\text { at Natick Laboratories } \\
\text { Apartments, Natick (7) }\end{array}$ & .13 & $\begin{array}{c}\text { Maximum } \\
\text { Minimum } \\
\text { No. of analyses }\end{array}$ & $\begin{array}{c}4.2 \\
1.4 \\
3\end{array}$ & $\begin{array}{r}119 \\
57 \\
3\end{array}$ & $\begin{array}{l}.07 \\
.01 \\
3\end{array}$ & $\begin{array}{l}.92 \\
.55 \\
3\end{array}$ & $\begin{array}{l}.66 \\
.27 \\
3\end{array}$ & $\begin{array}{l}1.5 \\
.86 \\
3\end{array}$ & $\begin{array}{l}.109 \\
.068 \\
3\end{array}$ & $\begin{array}{l}.276 \\
.106 \\
3\end{array}$ \\
\hline $\begin{array}{l}\text { Natick Laboratories } \\
\text { Pond at outlet, } \\
\text { Natick (9) }\end{array}$ & .24 & $\begin{array}{c}\text { Maximum } \\
\text { Minimum } \\
\text { No. of analyses }\end{array}$ & $\begin{array}{l}31 \\
3\end{array}$ & $\begin{array}{c}302 \\
96 \\
3\end{array}$ & $\begin{array}{l}.17 \\
.03 \\
3\end{array}$ & $\begin{array}{l}.50 \\
.27 \\
3\end{array}$ & $\begin{array}{l}.62 \\
.16 \\
3\end{array}$ & $\begin{array}{l}1.1 \\
.69 \\
3\end{array}$ & $\begin{array}{l}.088 \\
.010 \\
3\end{array}$ & $\begin{array}{l}.177 \\
.035 \\
3\end{array}$ \\
\hline $\begin{array}{l}\text { Storm-sewer outfall } \\
\text { near Lakewood Rd., } \\
\text { Natick (10) }\end{array}$ & .03 & $\begin{array}{c}\text { Maximum } \\
\text { Minimum } \\
\text { No. of analyses }\end{array}$ & $\begin{array}{l}.53 \\
.02 \\
4\end{array}$ & $\begin{array}{r}35 \\
14 \\
4\end{array}$ & $\begin{array}{l}.11 \\
.00 \\
4\end{array}$ & $\begin{array}{l}.18 \\
.03 \\
4\end{array}$ & $\begin{array}{l}.28 \\
.08 \\
4\end{array}$ & $\begin{array}{l}.38 \\
.20 \\
4\end{array}$ & $\begin{array}{l}.076 \\
.045 \\
4\end{array}$ & $\begin{array}{l}.154 \\
.089 \\
4\end{array}$ \\
\hline $\begin{array}{l}\text { Storm-sewer outfall } \\
\text { at State Route 9, } \\
\text { Natick (11) }\end{array}$ & .02 & $\begin{array}{c}\text { Maximum } \\
\text { Minimum } \\
\text { No. of analyses }\end{array}$ & $\begin{array}{l}.26 \\
.15 \\
2\end{array}$ & $\begin{array}{l}46 \\
31 \\
2\end{array}$ & $\begin{array}{l}.15 \\
.01 \\
2\end{array}$ & $\begin{array}{l}.23 \\
.14 \\
2\end{array}$ & $\begin{array}{l}.40 \\
.07 \\
2\end{array}$ & $\begin{array}{l}.55 \\
.45 \\
2\end{array}$ & $\begin{array}{l}.048 \\
.030 \\
2\end{array}$ & $\begin{array}{l}.093 \\
.075 \\
2\end{array}$ \\
\hline $\begin{array}{l}\text { Unnamed Brook at } \\
\text { North Main St., } \\
\text { Natick (12) }\end{array}$ & .27 & $\begin{array}{c}\text { Maximum } \\
\text { Minimum } \\
\text { No. of analyses }\end{array}$ & $\begin{array}{c}75 \\
2.1 \\
3\end{array}$ & $\begin{array}{l}60 \\
29 \\
3\end{array}$ & $\begin{array}{l}.04 \\
.00 \\
3\end{array}$ & $\begin{array}{l}.29 \\
.05 \\
3\end{array}$ & $\begin{array}{l}.47 \\
.05 \\
3\end{array}$ & $\begin{array}{l}.80 \\
.24\end{array}$ & $\begin{array}{l}.035 \\
.017 \\
3\end{array}$ & $\begin{array}{l}.114 \\
.081 \\
3\end{array}$ \\
\hline $\begin{array}{l}\text { Drainage ditch } \\
\text { beside Massachusetts } \\
\text { Turnpike, Natick (13) }\end{array}$ & .01 & $\begin{array}{c}\text { Maximum } \\
\text { Minimum } \\
\text { No. of analyses }\end{array}$ & $\begin{array}{l}.19 \\
.16 \\
2\end{array}$ & $\begin{array}{r}321 \\
76 \\
2\end{array}$ & $\begin{array}{l}.18 \\
.12 \\
2\end{array}$ & $\begin{array}{l}.40 \\
.22 \\
2\end{array}$ & $\begin{array}{l}.27 \\
.03 \\
2\end{array}$ & $\begin{array}{l}.61 \\
.61 \\
2\end{array}$ & $\begin{array}{l}.022 \\
.021 \\
2\end{array}$ & $\begin{array}{l}.173 \\
.061 \\
2\end{array}$ \\
\hline $\begin{array}{l}\text { Unnamed Brook at } \\
\text { State Route } 30 \text {, } \\
\text { Wayland (14) }\end{array}$ & .16 & $\begin{array}{c}\text { Maximum } \\
\text { Minimum } \\
\text { No. of analyses }\end{array}$ & $\begin{array}{c}3.1 \\
1.0 \\
3\end{array}$ & $\begin{array}{r}104 \\
40 \\
4\end{array}$ & $\begin{array}{l}.13 \\
.00 \\
4\end{array}$ & $\begin{array}{l}1.3 \\
.27 \\
4\end{array}$ & $\begin{array}{l}.66 \\
.23 \\
4\end{array}$ & $\begin{array}{l}2.1 \\
.83 \\
4\end{array}$ & $\begin{array}{l}.114 \\
.101 \\
4\end{array}$ & $\begin{array}{l}.247 \\
.144 \\
4\end{array}$ \\
\hline $\begin{array}{l}\text { Storm-sewer outfall } \\
\text { at Maguire Rd., } \\
\text { Wayland (15) }\end{array}$ & .03 & $\begin{array}{c}\text { Maximum } \\
\text { Minimum } \\
\text { No. of analyses }\end{array}$ & $\begin{array}{l}1.0 \\
.07 \\
3\end{array}$ & $\stackrel{32}{9}$ & $\begin{array}{l}.13 \\
.01 \\
3\end{array}$ & $\begin{array}{l}.16 \\
.07 \\
3\end{array}$ & $\begin{array}{l}.43 \\
.17 \\
3\end{array}$ & $\begin{array}{l}.72 \\
.26 \\
3\end{array}$ & $\begin{array}{l}.171 \\
.062 \\
3\end{array}$ & $\begin{array}{l}.267 \\
.100 \\
3\end{array}$ \\
\hline $\begin{array}{l}\text { Storm-sewer outfall } \\
\text { at Morrill Dr., } \\
\text { W ayland (16) }\end{array}$ & .03 & $\begin{array}{r}\text { Maximum } \\
\text { Minimum } \\
\text { No. of analyses }\end{array}$ & $\begin{array}{l}.25 \\
.01 \\
3\end{array}$ & $\begin{array}{c}52 \\
8 \\
3\end{array}$ & $\begin{array}{l}.08 \\
.01 \\
3\end{array}$ & $\begin{array}{l}.16 \\
.03 \\
3\end{array}$ & $\begin{array}{l}.33 \\
.02 \\
3\end{array}$ & $\begin{array}{l}.44 \\
.16 \\
3\end{array}$ & $\begin{array}{l}.105 \\
.052 \\
3\end{array}$ & $\begin{array}{l}.199 \\
.104 \\
3\end{array}$ \\
\hline $\begin{array}{l}\text { Storm-sewer outfall } \\
\text { at Parkridge Rd., } \\
\text { Wayland (17) }\end{array}$ & .01 & $\begin{array}{c}\text { Maximum } \\
\text { Minimum } \\
\text { No. of analyses }\end{array}$ & $\begin{array}{l}.24 \\
.04 \\
3\end{array}$ & $\begin{array}{r}24 \\
9 \\
3\end{array}$ & $\begin{array}{l}.04 \\
.00 \\
3\end{array}$ & $\begin{array}{l}.04 \\
.02 \\
3\end{array}$ & $\begin{array}{l}.58 \\
.18 \\
3\end{array}$ & $\begin{array}{l}.63 \\
.22 \\
3\end{array}$ & $\begin{array}{l}.101 \\
.075 \\
3\end{array}$ & $\begin{array}{l}.221 \\
.116 \\
3\end{array}$ \\
\hline $\begin{array}{l}\text { Storm-sewer outfall } \\
\text { at Town Beach, } \\
\text { Framingham (18) }\end{array}$ & .08 & $\begin{array}{c}\text { Maximum } \\
\text { Minimum } \\
\text { No. of analyses }\end{array}$ & $\begin{array}{l}1.4 \\
.23 \\
3\end{array}$ & $\begin{array}{l}54 \\
14 \\
3\end{array}$ & $\begin{array}{l}.10 \\
.02 \\
3\end{array}$ & $\begin{array}{l}.11 \\
.04 \\
3\end{array}$ & $\begin{array}{l}.70 \\
.02 \\
3\end{array}$ & $\begin{array}{l}.83 \\
.15 \\
3\end{array}$ & $\begin{array}{l}.110 \\
.037 \\
3\end{array}$ & $\begin{array}{l}.178 \\
.077 \\
3\end{array}$ \\
\hline $\begin{array}{l}\text { Storm-sewer outfall } \\
\text { at LaSalle Ave., } \\
\text { Framingham (19) }\end{array}$ & .01 & $\begin{array}{l}\text { Maximum } \\
\text { Minimum } \\
\text { No. of analyses }\end{array}$ & $\begin{array}{l}.39 \\
.08 \\
3\end{array}$ & $\begin{array}{c}53 \\
14 \\
3\end{array}$ & $\begin{array}{l}.13 \\
.04 \\
3\end{array}$ & $\begin{array}{l}.21 \\
.10 \\
3\end{array}$ & $\begin{array}{l}.59 \\
.05 \\
3\end{array}$ & $\begin{array}{l}.82 \\
.22 \\
3\end{array}$ & $\begin{array}{l}.147 \\
.013 \\
3\end{array}$ & $\begin{array}{l}.355 \\
.046 \\
3\end{array}$ \\
\hline \multicolumn{11}{|c|}{ MAJOR SURFACE-WATER SOURCES } \\
\hline $\begin{array}{l}\text { Beaverdam Brook } \\
\text { gaging station at } \\
\text { Mill St., Natick }\end{array}$ & 7.25 & $\begin{array}{c}\text { Maximum } \\
\text { Minimum } \\
\text { No. of analyses }\end{array}$ & $\begin{array}{r}214 \\
46 \\
3\end{array}$ & $\begin{array}{l}225 \\
112 \\
3\end{array}$ & $\begin{array}{l}.10 \\
.00 \\
3\end{array}$ & $\begin{array}{l}.29 \\
.20 \\
3\end{array}$ & $\begin{array}{l}.81 \\
.30 \\
3\end{array}$ & $\begin{array}{l}1.1 \\
.57 \\
3\end{array}$ & $\begin{array}{l}.044 \\
: 014 \\
3\end{array}$ & $\begin{array}{l}.193 \\
.102 \\
3\end{array}$ \\
\hline $\begin{array}{l}\text { Course Brook } \\
\text { gaging station at } \\
\text { Pond St., Natick }\end{array}$ & 3.42 & $\begin{array}{c}\text { Maximum } \\
\text { Minimum } \\
\text { No. of analyses }\end{array}$ & $\begin{array}{c}180 \\
7.0 \\
3\end{array}$ & $\begin{array}{r}170 \\
40 \\
3\end{array}$ & $\begin{array}{l}.07 \\
.01 \\
3\end{array}$ & $\begin{array}{l}.31 \\
.10 \\
3\end{array}$ & $\begin{array}{l}.31 \\
.25\end{array}$ & $\begin{array}{l}.63 \\
.42 \\
3\end{array}$ & $\begin{array}{l}.036 \\
.003 \\
3\end{array}$ & $\begin{array}{l}.070 \\
.046 \\
3\end{array}$ \\
\hline $\begin{array}{l}\text { Pegan Brook gaging } \\
\text { station at } \\
\text { mouth, Natick }\end{array}$ & .54 & $\begin{array}{r}\text { Maximum } \\
\text { Minimum } \\
\text { No. of analyses }\end{array}$ & $\begin{array}{c}16 \\
3.1 \\
3\end{array}$ & $\begin{array}{l}230 \\
151 \\
3\end{array}$ & $\begin{array}{l}.07 \\
.00 \\
3\end{array}$ & $\begin{array}{l}.95 \\
.29 \\
3\end{array}$ & $\begin{array}{l}.79 \\
.24 \\
3\end{array}$ & $\begin{array}{l}1.8 \\
.53 \\
3\end{array}$ & $\begin{array}{l}.033 \\
.019 \\
3\end{array}$ & $\begin{array}{l}.261 \\
.042 \\
3\end{array}$ \\
\hline $\begin{array}{l}\text { Snake Brook gaging } \\
\text { station at State } \\
\text { Highway } 27 \text {, Wayland }\end{array}$ & 2.10 & $\begin{array}{r}\text { Maximum } \\
\text { Minimum } \\
\text { No. of analyses }\end{array}$ & $\begin{array}{c}131 \\
6.9 \\
3\end{array}$ & $\begin{array}{r}154 \\
61 \\
\quad 3\end{array}$ & $\begin{array}{r}.03 \\
.01 \\
3\end{array}$ & $\begin{array}{r}.69 \\
.28 \\
3\end{array}$ & $\begin{array}{r}.67 \\
.24 \\
3\end{array}$ & $\begin{array}{r}1.4 \\
.72 \\
3\end{array}$ & $\begin{array}{r}.037 \\
.003 \\
3\end{array}$ & $\begin{array}{r}.139 \\
.077 \\
3\end{array}$ \\
\hline
\end{tabular}


Table 9.--Concentrations of nutrient species, in milligrams per liter, entering Lake Cochituate from representative storm sewers during the April 26-27, 1979, rainstorm

[ Number in parentheses refers to plate 1; identical number given to station on plate 1 in Gay, 1981]

Storm-sewer outfall at

Possum Hollow Lane, Natick (4)
Storm-sewer outfall at Crescent Street, Natick (5)
Drainage area, in square miles

Time of sample collection

Instantaneous streamflow, in gallons per minute

Water temperature, in degrees Celsius

Specific conductance, in micromhos per centimeter at $25^{\circ} \mathrm{C}$

Total ammonia nitrogen as nitrogen

Total nitrite plus nitrate nitrogen as nitrogen

Total organic nitrogen as nitrogen

Total nitrogen as nitrogen

Total or thophosphate phosphorus as phosphorus

Total phosphorus as phosphorus
0.05

1425

1250

1335

18

54

3.2

300

13.5

14.5

13.0

16.0

117

65

86

25

.01

.01

.01

.00

.59

.34

.52

.09

.25

.16

.25

.22

.85

.51

.78

.31

.029

.044

.023

.032

.054

.141

.082 


\section{Nutrient Loads in Major Surface-Water Sources}

Estimated monthly loads of the various nutrient species were computed for each surface-water source entering Fisk Pond (table 10) and Lake Cochituate (table 11). Analysis of estimated monthly nutrient loads entering Lake Cochituate from surface-water sources during November 1977 through May 1979 shows Fisk Pond to be the single largest contributor. During this period, about 60 percent of the total nitrogen and about 71 percent of the total phosphorus loads entered Lake Cochituate through Fisk Pond outlet. Combined flows of Pegan and Snake Brooks contributed about 23 percent of the total nitrogen and about 15 percent of the total phosphorus loads; whereas, the ungaged area draining into Lake Cochituate contributed about 17 percent of the total nitrogen and about 14 percent of the total phosphorus loads to Lake Cochituate for the 19-month period.

Assuming the gain or loss of nutrients to Fisk Pond sediments was proportional to the load from each nutrient source (Beaverdam and Course Brooks and the ungaged area draining into Fisk Pond), Beaverdam Brook contributed about 41 percent of the total nitrogen and about 53 percent of the total phosphorus loads to Lake Cochituate. Course Brook contributed about 16 percent of the total nitrogen and about 15 percent of the total phosphorus loads to Lake Cochituate. Therefore, Beaverdam Brook indirectly contributed about half the nutrient loads to Lake Cochituate from all surface-water sources for that period.

The eyclical pattern of the total nitrogen (fig. 6) and total phosphorus (fig. 7) loads entering Lake Cochituate from surface-water sources is shown for the 12-month period April 1978 through March 1979. From visual inspection of these figures (6 and 7), it appears that Beaverdam Brook is the largest monthly contributor of nitrogen and phosphorus to Fisk Pond and the pond is the largest monthly contributor of both nutrients to the lake on annual basis.

There is a direct relation between nutrient loads and runoff entering Lake Cochituate as shown in figure 8. The same relation holds for all streams and is similar to one for Beaverdam Brook (fig. 9). Figure 8 shows that a high percentage of the nutrients enter Lake Cochituate during late fall, winter, and early spring when streamflow is high. A summation of monthly percentages in figure 8 shows 32 percent of the total surface-water runoff entered Lake Cochituate during April through October; whereas, 68 percent flowed in during November through March. For this same period, only 31 percent of the total nitrogen and 27 percent of the total phosphorus loads entered Lake Cochituate from April through October; however, 69 percent of the total nitrogen and 73 percent of the total phosphorus loads entered during November through March, a 5-month period. This indicates that any time streamflow is high, large quantities of nutrients will be carried into the lake because nutrient concentrations do not vary greatly during the year even though there is substantial variation in streamflow.

Vollenweider's equation presented in the "Significance of nutrient concentrations on lake-water quality" was used to compute a total phosphorus concentration of $0.031 \mathrm{mg} / \mathrm{L}$ in South Pond from the annual total phosphorus load contributed by Fisk Pond and Pegan Brook. This value was based on the combined water volumes and total phosphorus loads of both sources during the period April 1978 through March 1979. Physical characteristics of South Pond, mean depth of 19.9 feet and a surface area of $0.364 \mathrm{mi}^{2}$, were taken from Beskenis and others (1982). If the phosphorus loading of 2,180 pounds to South Pond for the 12-month period, April 1978 through March 1979, is representative of the annual load then the equivalent total phosphorus concentration of $0.031 \mathrm{mg} / \mathrm{L}$ is about 50 percent greater than what is commonly considered a sufficient total phosphorus concentration $(0.02 \mathrm{mg} / \mathrm{L})$ to cause and to sustain nuisance aquatic-plant growth and eutrophic conditions in lake water.

To apply this approach to Carling Pond the total phosphorus load contributed by South Pond would have to be known. The load from South Pond to Carling Pond probably differs from the load of Fisk Pond and Pegan Brook to South Pond by whatever was gained or lost (more likely lost) in South Pond. 
Table 10.--Estimated monthly nutrient loads entering and leaving Fisk Pond from surface-water sources

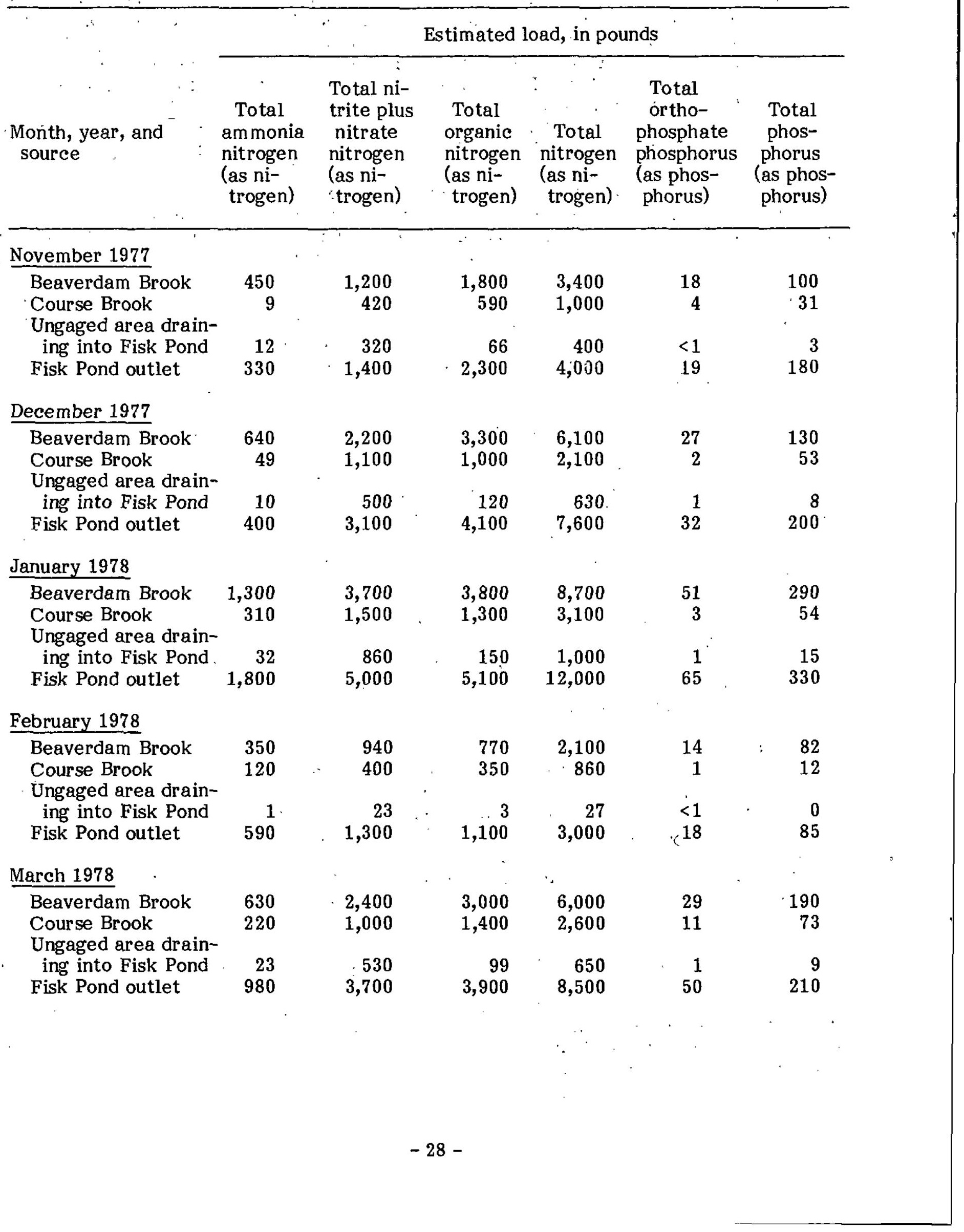


Table 10.--Estimated monthly nutrient loads entering and leaving Fisk. Pond from surface-water sources (Continued)

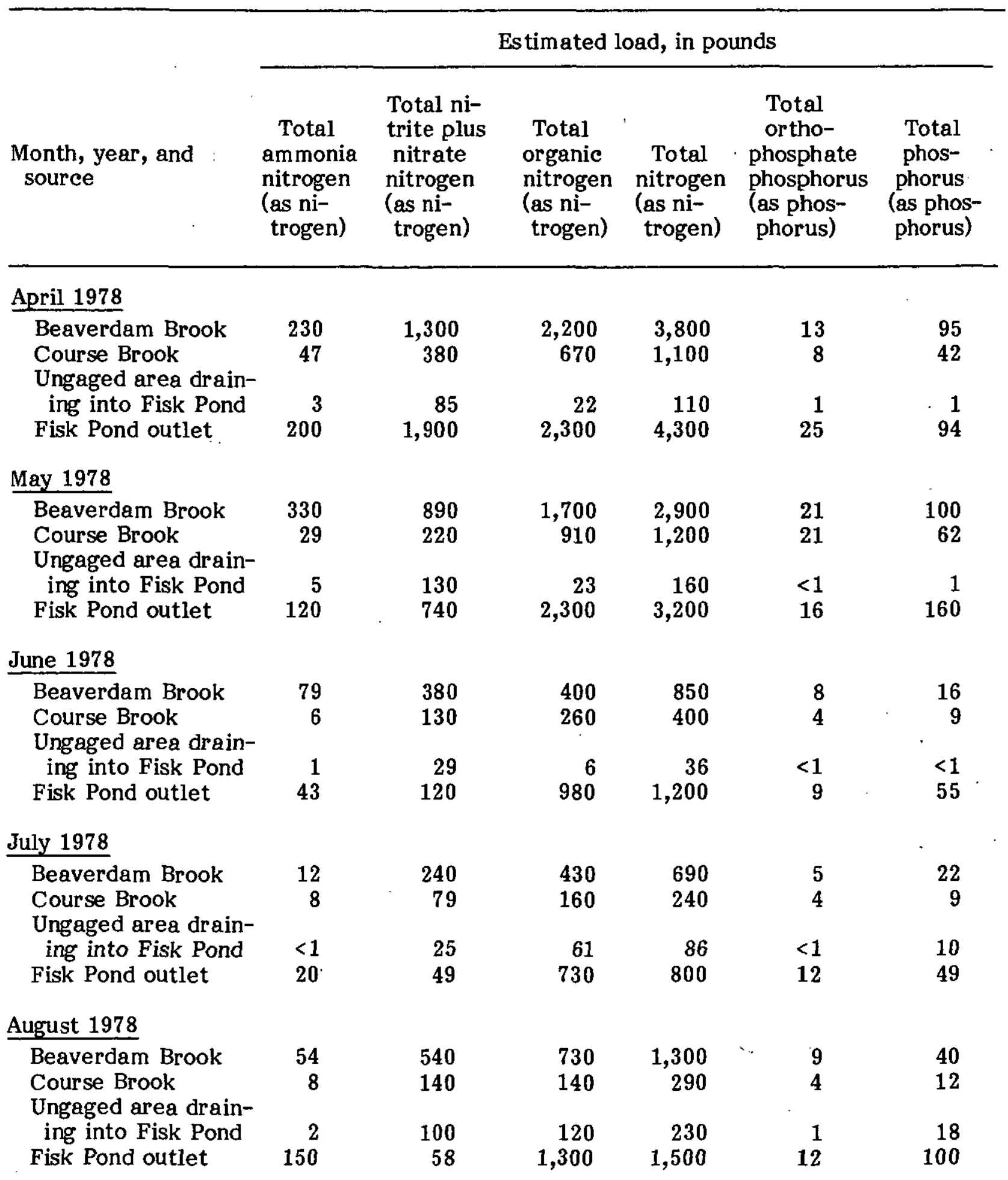


Table 10.-Estimated monthly nutrient loads entering and leaving Fisk Pond from surface-water sources (Continued)

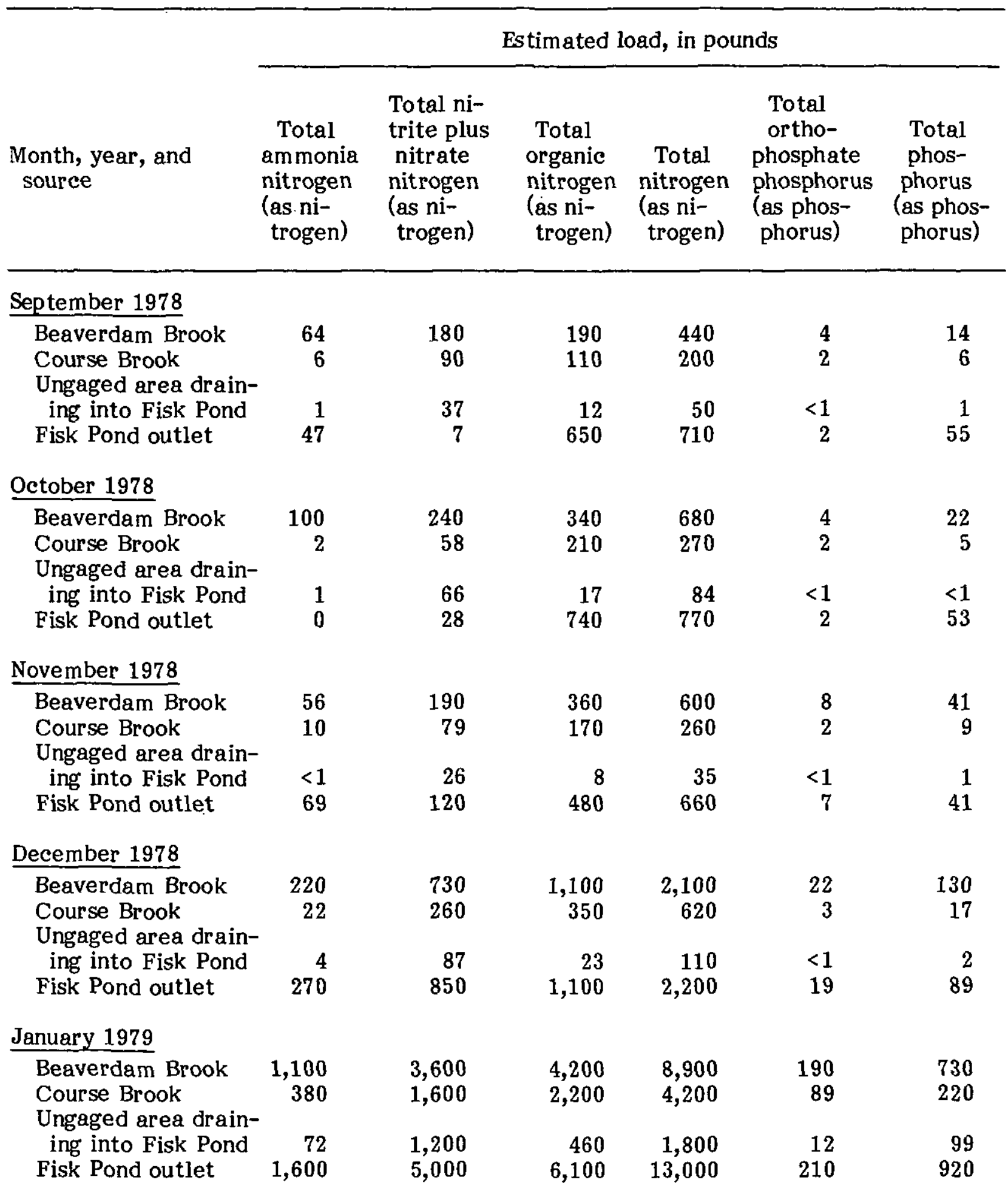


Table 10.-Estimated monthly nutrient loads entering and leaving Fisk Pond from surface-water sources (Continued)

\begin{tabular}{|c|c|c|c|c|c|c|}
\hline \multirow[b]{2}{*}{$\begin{array}{l}\text { Month, year, and } \\
\text { source }\end{array}$} & \multicolumn{6}{|c|}{ Estimated load, in pounds } \\
\hline & $\begin{array}{l}\text { Total } \\
\text { ammonia } \\
\text { nitrogen } \\
\text { (as ni- } \\
\text { trogen) }\end{array}$ & $\begin{array}{l}\text { Total ni- } \\
\text { trite plus } \\
\text { nitrate } \\
\text { nitrogen } \\
\text { (as ni- } \\
\text { trogen) }\end{array}$ & $\begin{array}{l}\text { Total } \\
\text { organic } \\
\text { nitrogen } \\
\text { (as ni- } \\
\text { trogen) }\end{array}$ & $\begin{array}{l}\text { Total } \\
\text { nitrogen } \\
\text { (as ni- } \\
\text { trogen) }\end{array}$ & $\begin{array}{l}\text { Total } \\
\text { ortho- } \\
\text { phosphate } \\
\text { phosphorus } \\
\text { (as phos- } \\
\text { phorus) }\end{array}$ & $\begin{array}{l}\text { Total } \\
\text { phos- } \\
\text { phorus } \\
\text { (as phos- } \\
\text { phorus) }\end{array}$ \\
\hline \multicolumn{7}{|l|}{ February 1979} \\
\hline Beaverdam Brook & 140 & 940 & 890 & 2,000 & 16 & 160 \\
\hline Course Brook & 210 & 490 & 390 & 1,100 & 7 & 36 \\
\hline $\begin{array}{l}\text { Ungaged area drain- } \\
\text { ing into Fisk Pond } \\
\text { Fisk Pond outlet }\end{array}$ & $\begin{array}{r}5 \\
330\end{array}$ & $\begin{array}{r}140 \\
1,400\end{array}$ & $\begin{array}{r}17 \\
1,400\end{array}$ & $\begin{array}{r}160 \\
3,100\end{array}$ & $\begin{array}{l}<1 \\
28\end{array}$ & $\begin{array}{r}1 \\
140\end{array}$ \\
\hline \multicolumn{7}{|l|}{ March 1979} \\
\hline $\begin{array}{l}\text { Beaverdam Brook } \\
\text { Course Brook } \\
\text { Ungaged area drain- }\end{array}$ & $\begin{array}{l}300 \\
260\end{array}$ & $\begin{array}{r}1,700 \\
880\end{array}$ & $\begin{array}{r}2,000 \\
730\end{array}$ & $\begin{array}{l}4,000 \\
1,900\end{array}$ & $\begin{array}{r}28 \\
9\end{array}$ & $\begin{array}{r}350 \\
57\end{array}$ \\
\hline $\begin{array}{l}\text { ing into Fisk Pond } \\
\text { Fisk Pond outlet }\end{array}$ & $\begin{array}{r}6 \\
520\end{array}$ & $\begin{array}{r}150 \\
2,600\end{array}$ & $\begin{array}{r}17 \\
3,200\end{array}$ & $\begin{array}{r}170 \\
6,300\end{array}$ & $\begin{array}{l}<1 \\
43\end{array}$ & $\begin{array}{r}1 \\
280\end{array}$ \\
\hline \multicolumn{7}{|l|}{ April 1979} \\
\hline $\begin{array}{l}\text { Beaverdam Brook } \\
\text { Course Brook } \\
\text { Ungaged area drain- }\end{array}$ & $\begin{array}{r}260 \\
51\end{array}$ & $\begin{array}{r}1,400 \\
480\end{array}$ & $\begin{array}{r}1,500 \\
520\end{array}$ & $\begin{array}{l}3,100 \\
1,000\end{array}$ & $\begin{array}{r}19 \\
7\end{array}$ & $\begin{array}{r}140 \\
.42\end{array}$ \\
\hline $\begin{array}{l}\text { ing into Fisk Pond } \\
\text { Fisk Pond outlet }\end{array}$ & $\begin{array}{r}6 \\
310\end{array}$ & $\begin{array}{r}160 \\
1,700\end{array}$ & $\begin{array}{r}22 \\
2,300\end{array}$ & $\begin{array}{r}190 \\
4,300\end{array}$ & $\begin{array}{r}1 \\
11\end{array}$ & $\begin{array}{r}2 \\
200\end{array}$ \\
\hline \multicolumn{7}{|l|}{ May 1979} \\
\hline $\begin{array}{l}\text { Beaverdam Brook } \\
\text { Course Brook }\end{array}$ & $\begin{array}{r}230 \\
15\end{array}$ & $\begin{array}{r}1,000 \\
310\end{array}$ & $\begin{array}{r}1,300 \\
540\end{array}$ & $\begin{array}{r}2,600 \\
870\end{array}$ & $\begin{array}{r}0 \\
31\end{array}$ & $\begin{array}{l}90 \\
54\end{array}$ \\
\hline $\begin{array}{l}\text { Ungaged area drain- } \\
\text { ing into Fisk Pond } \\
\text { Fisk Pond outlet }\end{array}$ & $\begin{array}{r}2 \\
370\end{array}$ & $\begin{array}{l}160 \\
920\end{array}$ & $\begin{array}{r}36 \\
2,900\end{array}$ & $\begin{array}{r}200 \\
4,200\end{array}$ & $\begin{array}{l}0 \\
0\end{array}$ & $\begin{array}{r}1 \\
18\end{array}$ \\
\hline
\end{tabular}


Table 11.-Estimated monthly nutrient loads entering Lake Cochituate from surface-water sources

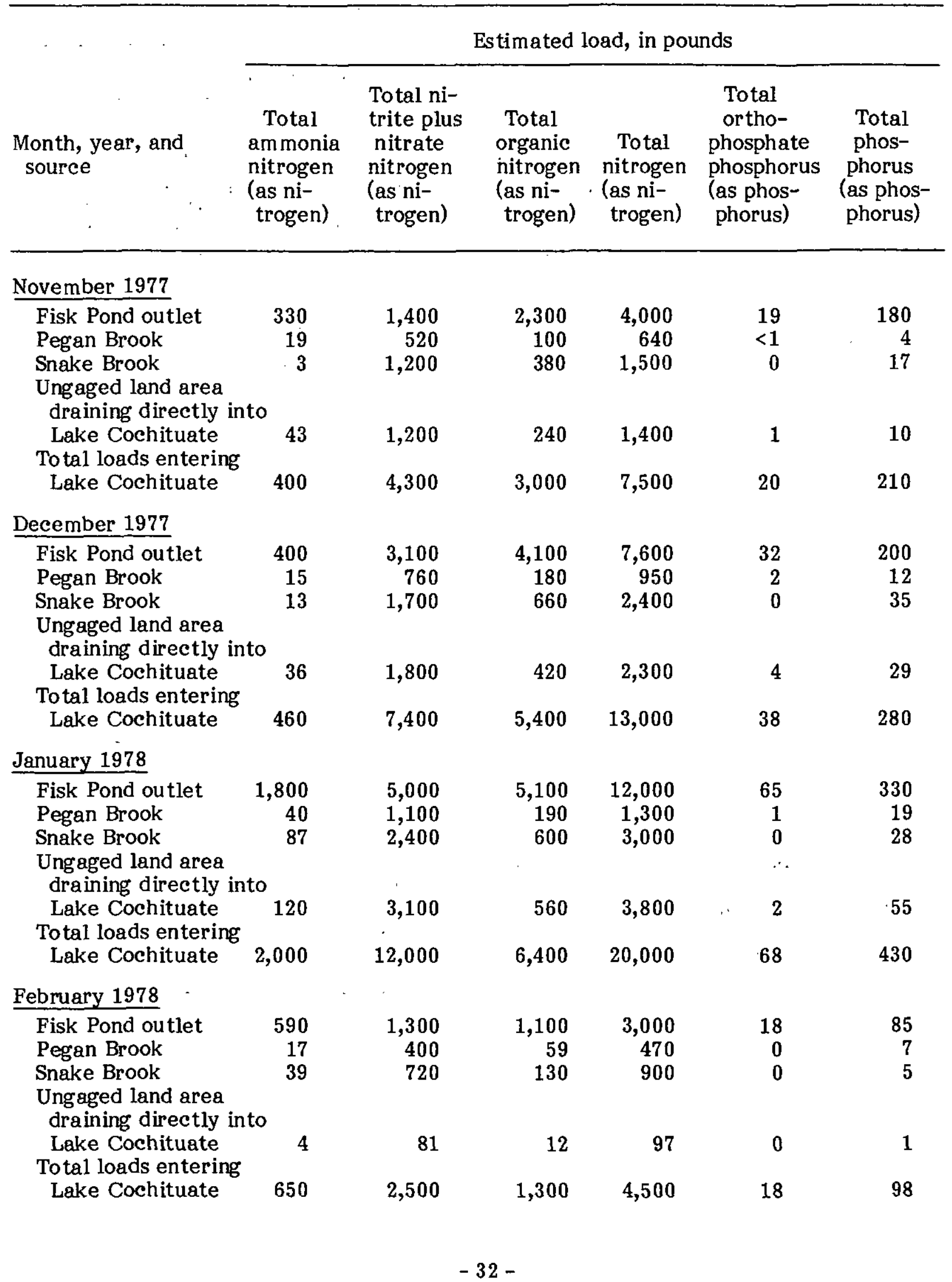


Table 11.-Estimated monthly nutrient loads entering Lake Cochituate from surface-water sources (Continued)

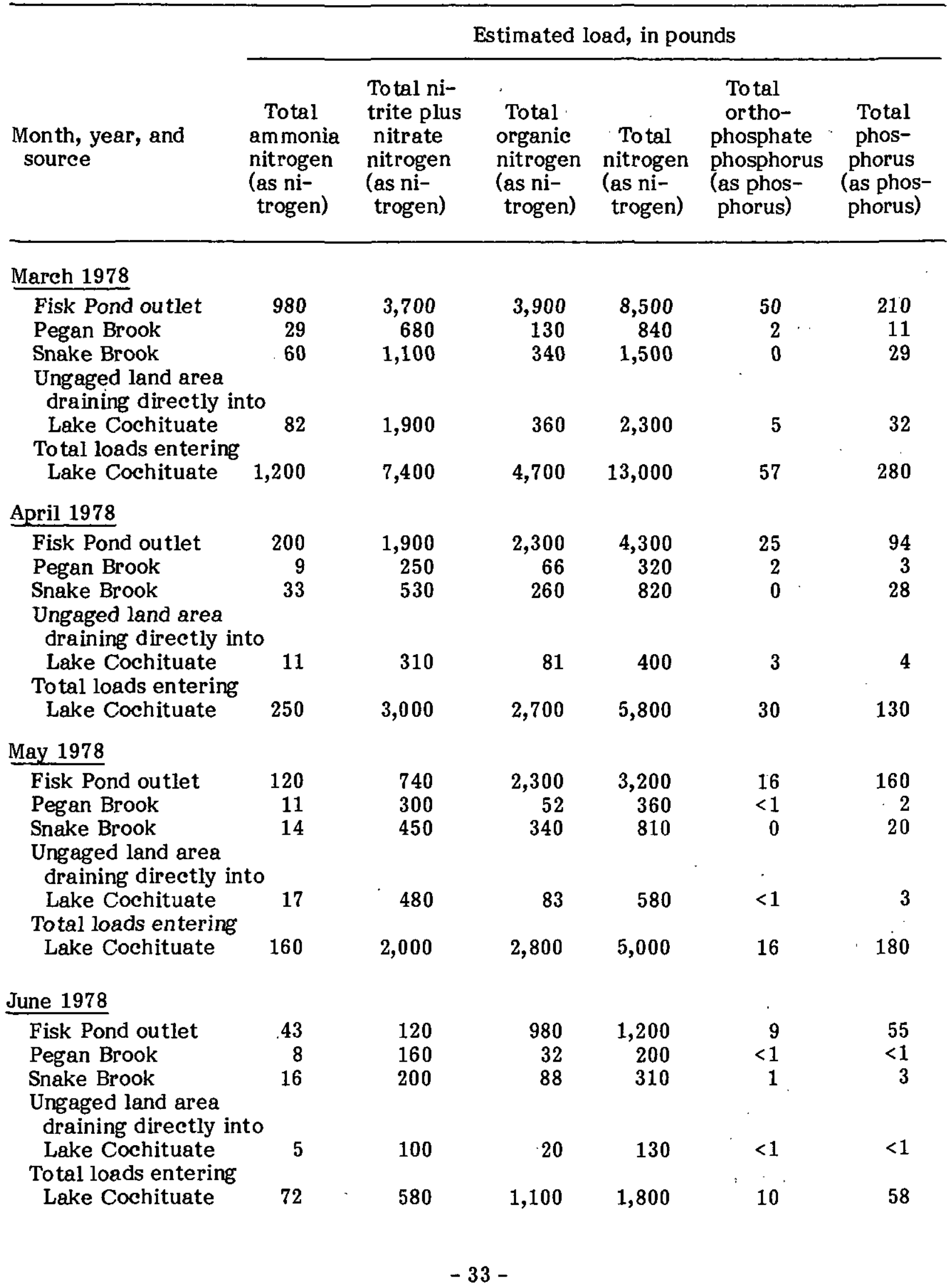


Table 11.-Estimated monthly nutrient loads entering Lake Cochituate from surface-water sources (Continued)

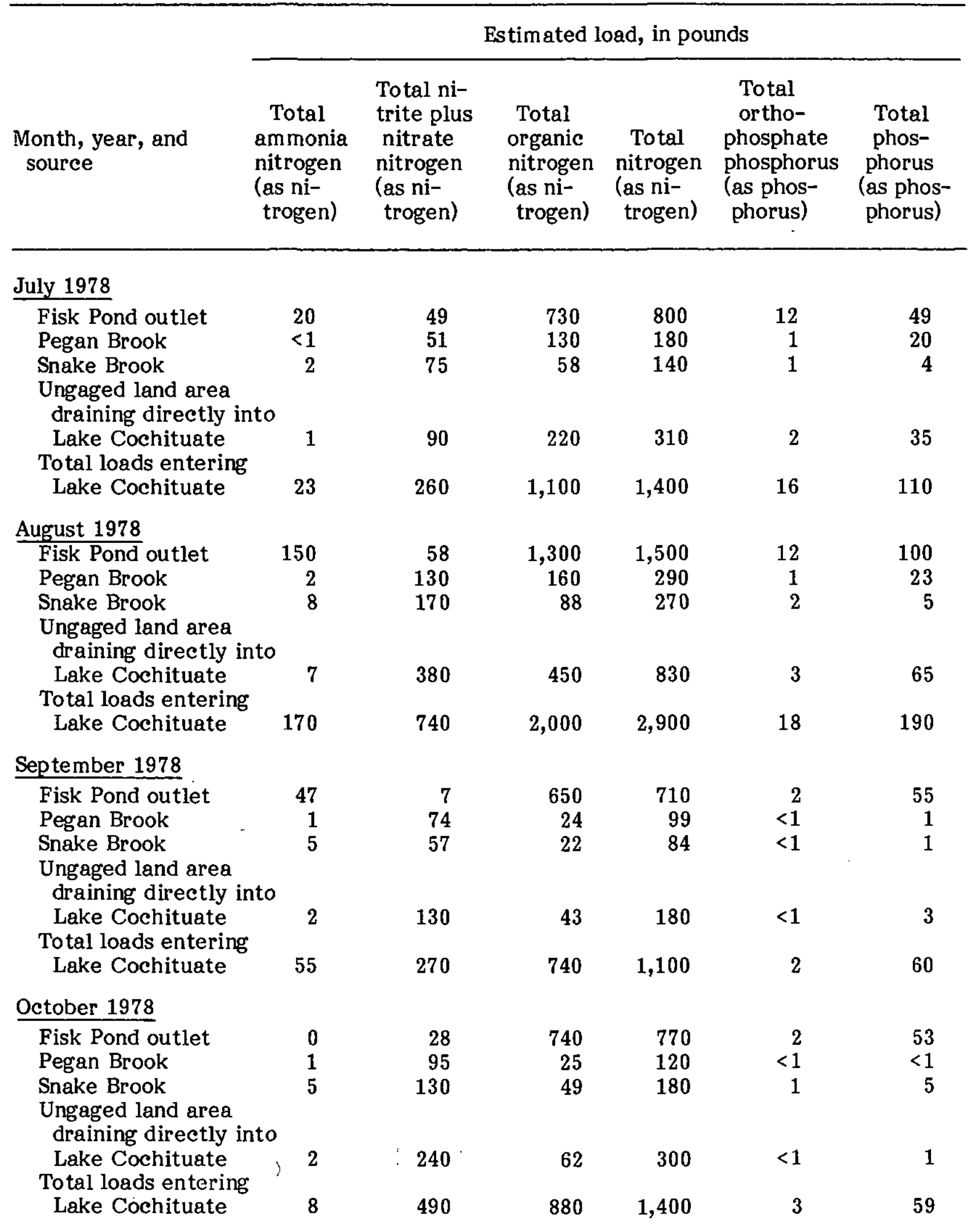


Table 11.-Estimated monthly nutrient loads entering Lake Cochituate from surface-water sources (Con tinued)

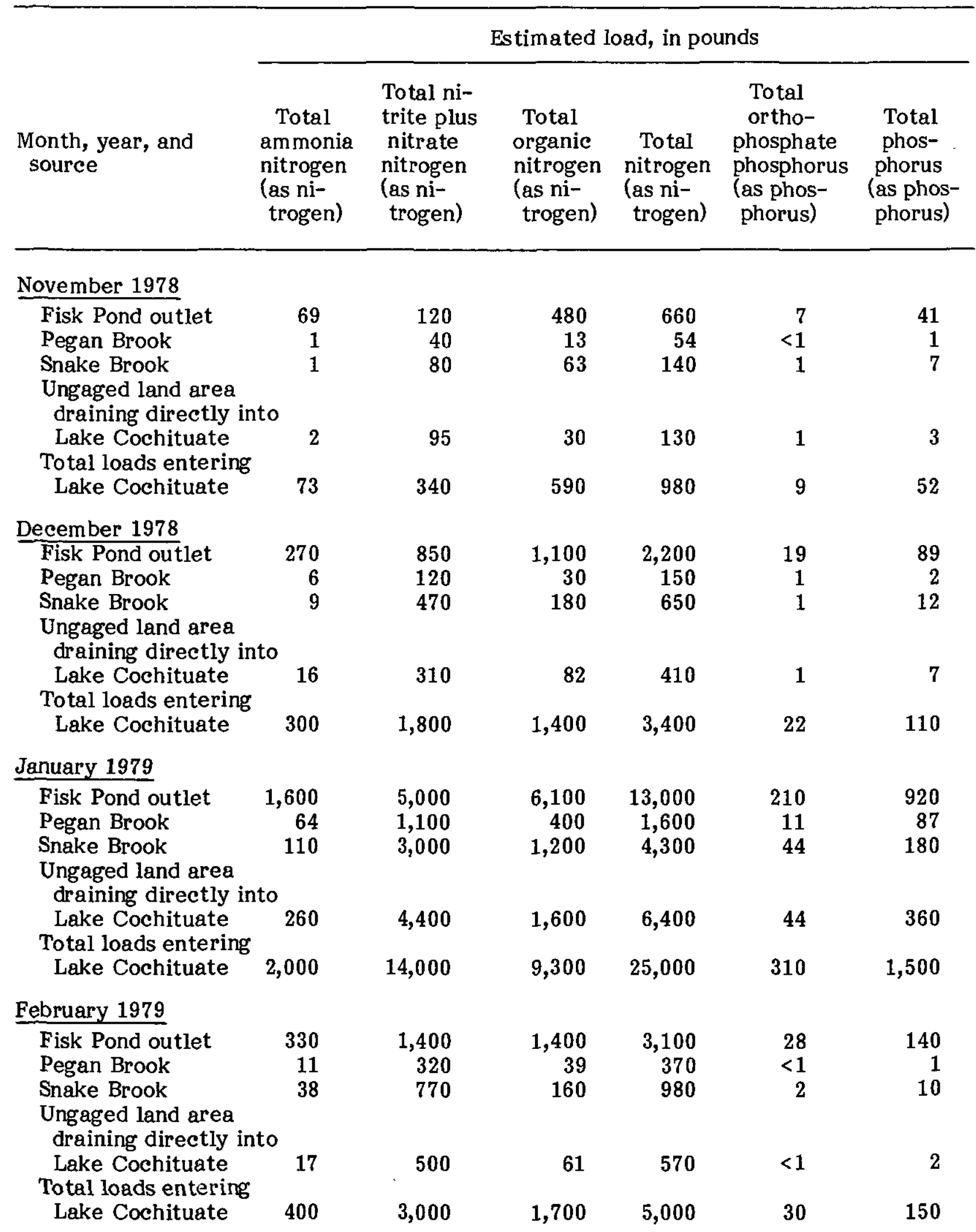


Table 11.-Estimated monthly nutrient loads entering Lake Cochituate from surface-water sources (Continued)

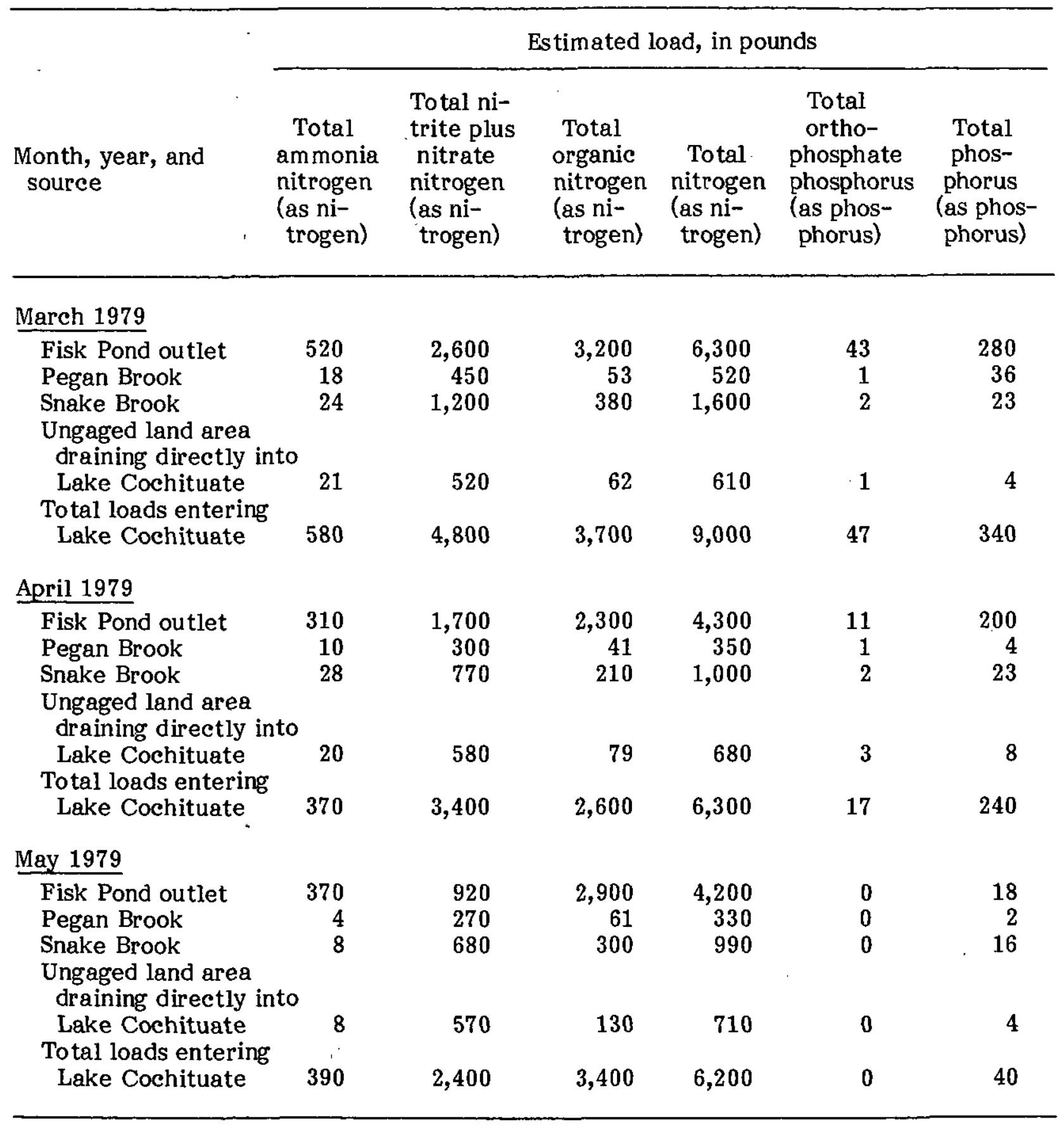




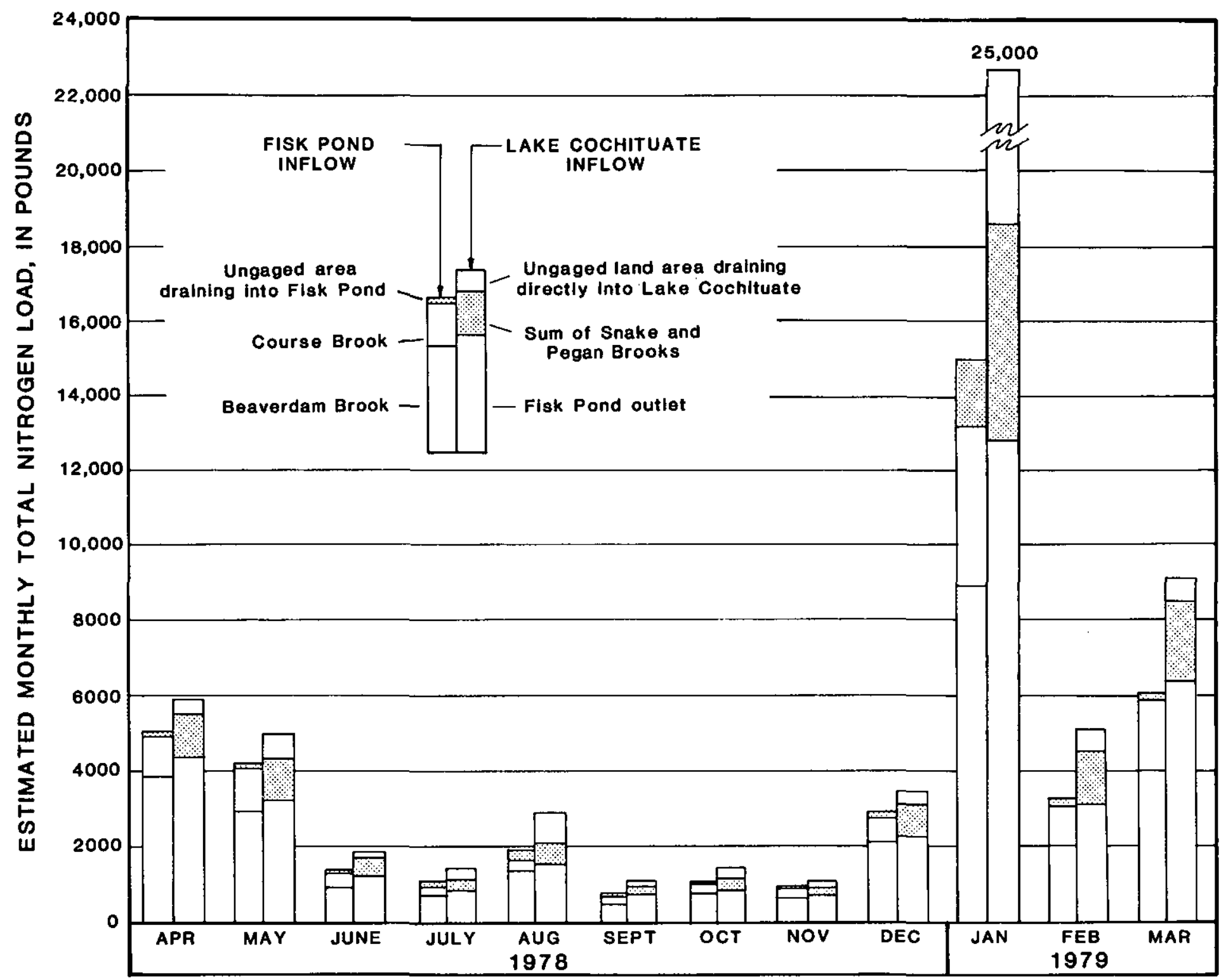

Figure 6.--Estimated monthly total nitrogen loads entering Fisk Pond and Lake Cochituate from surface-water sources for the period April 1978 through March 1979. 


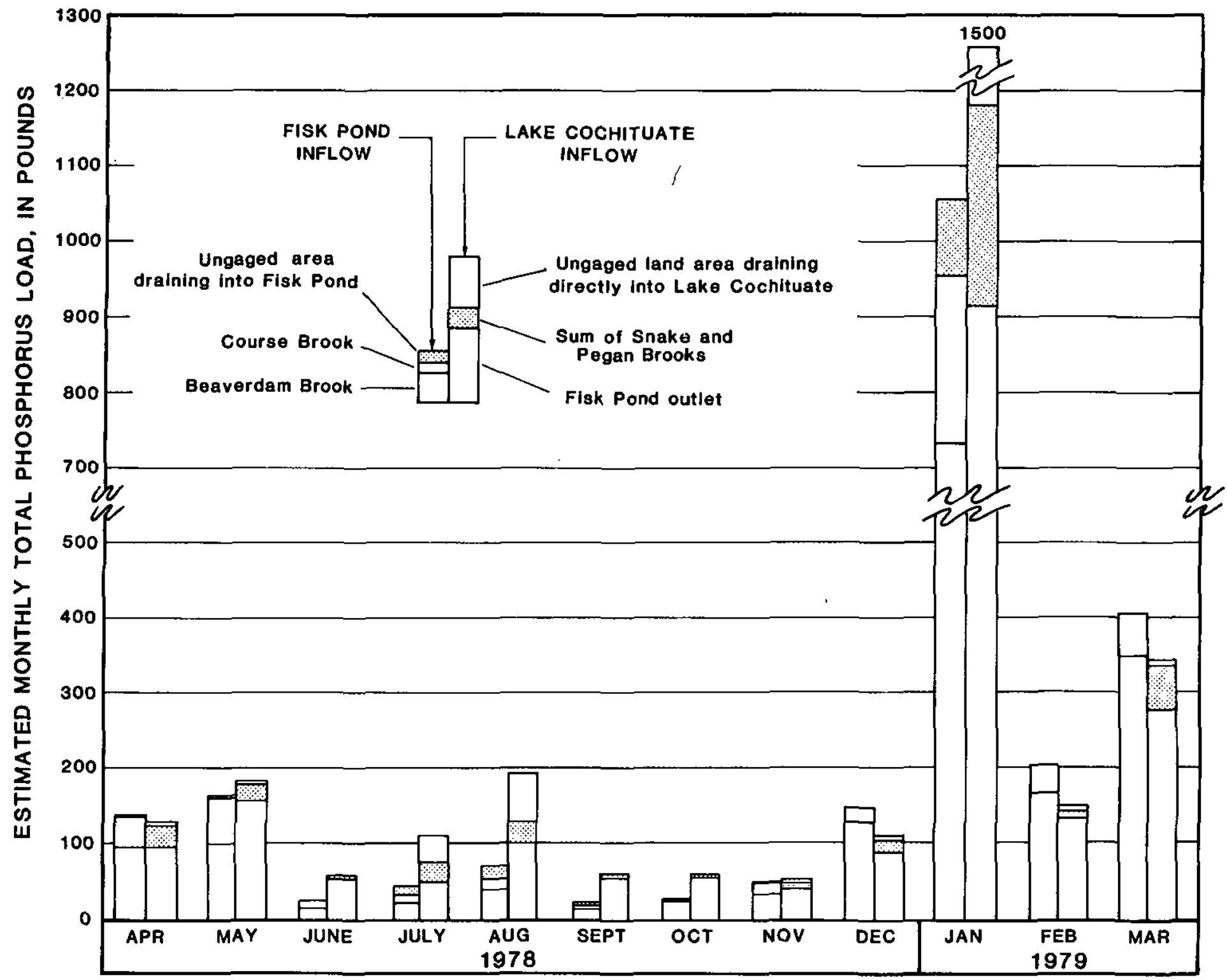

Figure 7.--Estimated monthly total phosphorus loads entering Fisk Pond and Lake Cochituate from surface-water sources for the period April 1978 through March 1979. 


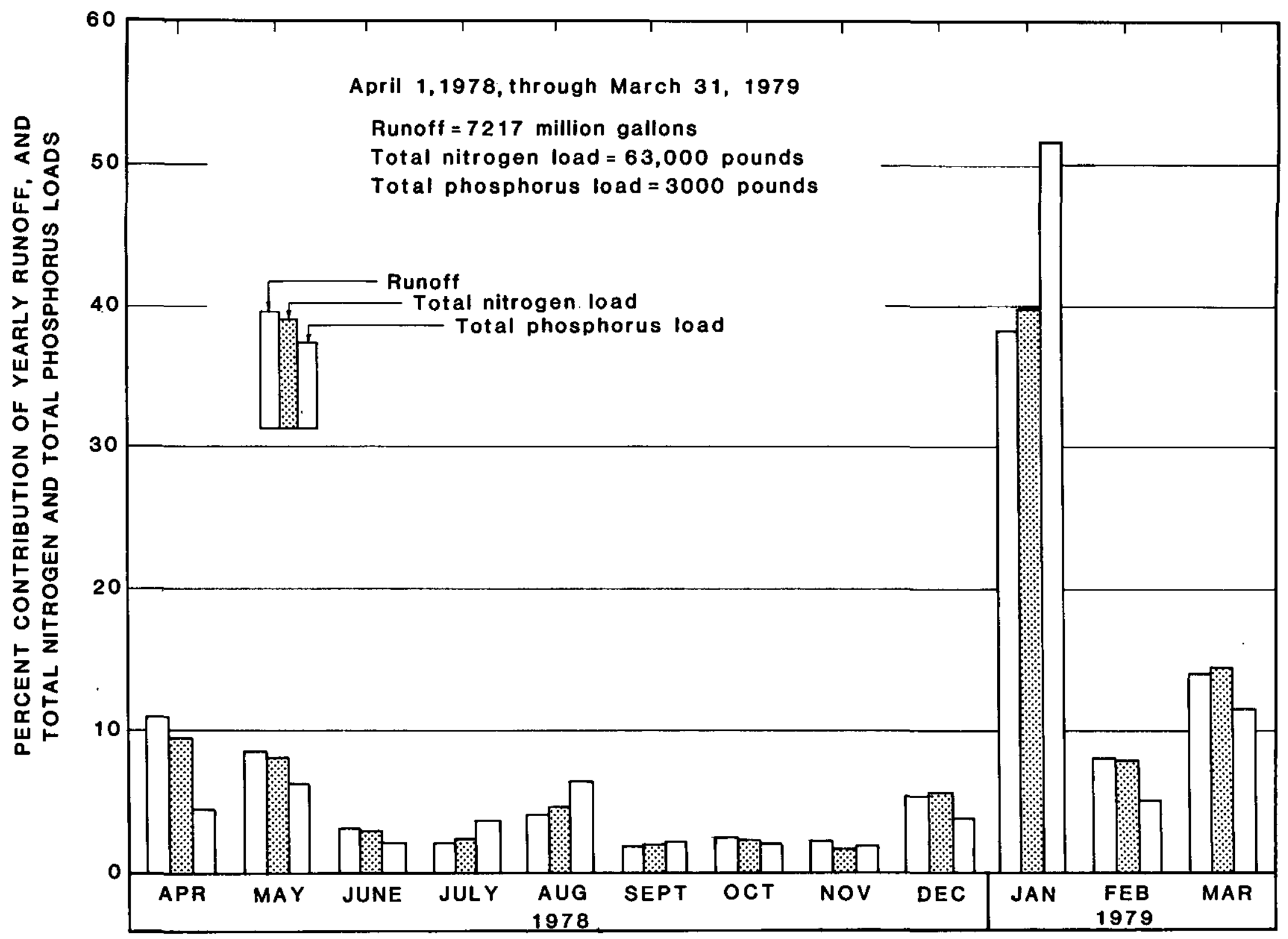

Figure 8.-- Percent contribution by month of yearly runoff, and total nitrogen and total phosphorus loads entering Lake Cochituate from surface-water sources for the period April 1978 through March 1979. 


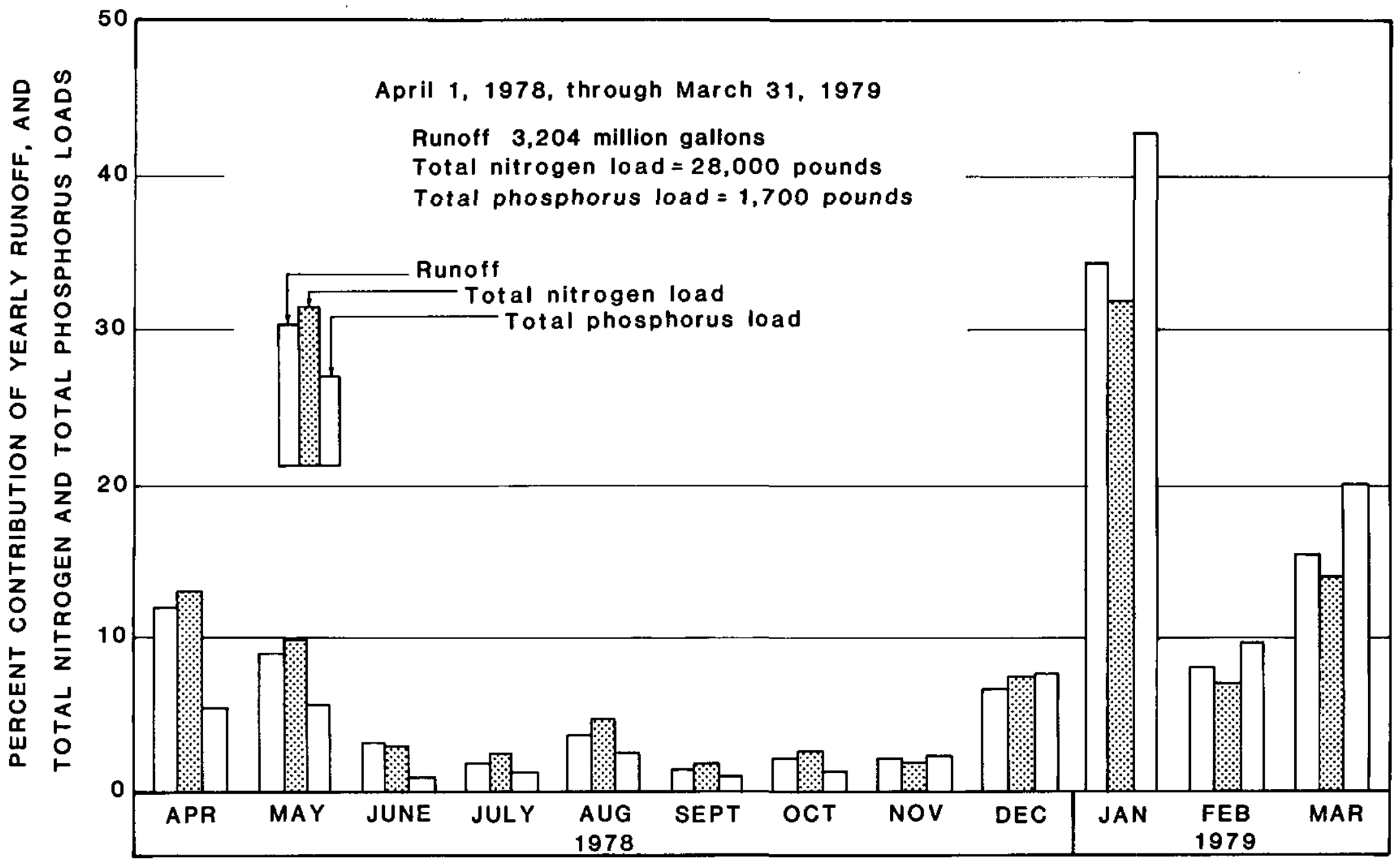

Figure 9.--Percent contribution by month of yearly runoff, and total nitrogen and total phosphorus loads at Beaverdam Brook gaging station. 


\section{Ground Water}

Analysis of water-level and nutrient concentration data from observation wells installed in the unconsolidated deposits around the periphery of Lake Cochituate's four ponds (South, Carling, Middle, and North Ponds) show that there are three sites (1, 2, and 5 on pl. 1) where ground water discharges to the lake and two of these (sites 2 and 5) are most significant in terms of nutrient loading of the lake. Three sites $(3,4$, and 7 on pl. 1) represent areas of ground-water exfiltration from the lake, two because of withdrawal from well fields for municipal supply and one because of a natural ground-water gradient across the surface-water (topographic) divide into another drainage basin. One site ( 6 on pl. 1) showed evidence of discharge to the lake from a shallow unconfined aquifer and exfiltration from the lake through a deeper confined aquifer.

The west shore of the North Pond (site 1) is a sewered residential area of Framingham where the basin drainage divide is not more than 1,000 feet from the lake shore. A test boring at this site $(\mathrm{F} 1 \mathrm{~A}-86)$ showed that the sediments are predominantly silt with some minor layers of fine sand down to 115 feet below lake level. Total nitrogen and total phosphorus from an observation well $(\mathrm{F} 1 \mathrm{~W}-85)$ at this site averaged $2.3 \mathrm{mg} / \mathrm{L}$ and $0.008 \mathrm{mg} / \mathrm{L}$, respectively. Although ground-water flow at this site is toward the lake, the quantity of flow is very small and the load of nutrients contributed to the lake from this area is inconsequential in comparison to other sources.

The west shore of the Middle and Carling Ponds (site 2) is a sewered industrial and commercial area of Natick which at one time contained a brewery. Records from wells and test borings in this area indicate that the site is underlain by over 200 feet of sand and gravel with some scat tered lenses of silt and clay. Total nitrogen and total phosphorus in ground-water samples from the area averaged $3.4 \mathrm{mg} / \mathrm{L}$ and $0.015 \mathrm{mg} / \mathrm{L}$, respectively. The average gradient toward the lake in the sand and gravel as indicated from monthly water levels taken from July 1978 to July 1979 in two wells, NCW-65 and -66 (pl. 1), was 0.0027 feet per foot. A transmissivity of $940 \mathrm{ft}^{2} / \mathrm{d}$ was computed from lithologic data for well NCW-65 and the hydraulic gradient and nutrient concentrations of ground water from this well were assumed to represent average conditions along 1,800 feet of shoreline labeled X-X' (site 2, pl. 1).

Estimated monthly discharge along the shoreline at site 2 during the period July 1978 through June 1979 ranged from 0.61 to $1.31 \mathrm{Mgal}$ per month with an average rate of $1.05 \mathrm{Mgal}$ per month (table 12). For the same period, the estimated monthly load of total nitrogen ranged from 15 to 38 pounds per month with an average rate of 29 pounds per month. Also, the estimated load of total phosphorus ranged from less than 0.1 to 0.3 pound per month. For this entire period, the total estimated ground-water and nutrient discharges to the lake at this site were estimated to be $12.6 \mathrm{Mgal}$ of water, 350 pounds of nitrogen, and 1.5 pounds of phosphorus.

Assuming that the $12.6 \mathrm{Mgal}$ of ground-water is recharged through a rectangular area 1,800 feet long (the length of the shoreline) by 800 feet wide (average distance between the shoreline and the divide) and average recharge rate of about 14 inches of recharge per year would be required. This estimate is in fairly close agreement with estimated recharge rates for sand and gravel in Massachusetts (Guswa and LeBlanc, 1981).

On a peninsula between the South and Middle Ponds the Springvale well field ( $\mathrm{NCW}-1$ through -4$)$ diverts water from the lake and the surrounding area (site 3 , pl. 1) for the municipal supply of Natick. The sand and gravel aquifer extends beneath the lake, and water-level gradients in observation wells $\mathrm{NCW}-56,-57$, and -59 (east side South Pond) and NCW-63 and -64 (west side South Pond) indicate that the well field draws water from the sewered and septic system served areas on both the east and west sides of South Pond. In addition, similar conditions probably exist adjacent to the east side of Middle Pond (site 4, pl. 1), but most of the water withdrawn by the Evergreen well field is derived from induced infiltration of lake water. 
Table 12.-Estimated monthly runoff and nutrient loads entering Middle Pond from ground-water sources at site 2

\begin{tabular}{|c|c|c|c|c|c|c|c|}
\hline \multirow[b]{2}{*}{$\begin{array}{l}\text { Local well } \\
\text { number/average } \\
\text { depth below } \\
\text { water table } \\
\text { to center of } \\
\text { well screen } \\
\text { (feet) }\end{array}$} & \multirow[b]{2}{*}{$\begin{array}{r}\text { Type of } \\
\text { statistic }\end{array}$} & \multicolumn{6}{|c|}{ Concentration, in milligrams per liter } \\
\hline & & $\begin{array}{l}\text { Total } \\
\text { ammonia } \\
\text { nitrogen } \\
\text { (as ni- } \\
\text { trogen) }\end{array}$ & $\begin{array}{l}\text { Total } \\
\text { nitrite } \\
\text { plus } \\
\text { nitrate } \\
\text { nitrogen } \\
\text { (as ni- } \\
\text { trogen) }\end{array}$ & $\begin{array}{l}\text { Total } \\
\text { organic } \\
\text { nitrogen } \\
\text { (as ni- } \\
\text { trogen) }\end{array}$ & $\begin{array}{l}\text { Total } \\
\text { nitrogen } \\
\text { (as ni- } \\
\text { trogen) }\end{array}$ & $\begin{array}{l}\text { Total } \\
\text { or tho- } \\
\text { phosphate } \\
\text { phos- } \\
\text { phorus } \\
\text { (as phos- } \\
\text { phorus) }\end{array}$ & $\begin{array}{l}\text { Total } \\
\text { phos- } \\
\text { phorus } \\
\text { (as } \\
\text { phos- } \\
\text { phorus) }\end{array}$ \\
\hline \multirow[t]{4}{*}{$\mathrm{NCW}-65 / 14.3$} & Maximum & 0.06 & 4.2 & 0.30 & 4.2 & 0.002 & 0.038 \\
\hline & Average & .02 & 3.3 & .12 & 3.4 & .001 & .015 \\
\hline & Minimum & .00 & 2.7 & .01 & 2.9 & .000 & .001 \\
\hline & $\begin{array}{l}\text { No. of } \\
\text { analyses }\end{array}$ & 5 & 5 & 5 & 5 & 5 & 5 \\
\hline \multicolumn{8}{|c|}{ Ground-water runoff and nutrient loads } \\
\hline Month & $\begin{array}{l}\text { Estimated } \\
\text { flow } \\
\text { per foot of } \\
\text { shoreline } \\
\text { (gallons) }\end{array}$ & $\begin{array}{r}\text { Esti } \\
\text { fl } \\
\text { from } 1 \\
\text { of sh } \\
\text { (millio }\end{array}$ & $\begin{array}{l}\text { mated } \\
\text { ow } \\
800 \text { feet } \\
\text { oreline } \\
n \text { gallons) }\end{array}$ & $\begin{array}{r}\text { Esti } \\
t \\
\text { nitrog } \\
\text { from } 1 \\
\text { of sh } \\
\text { (po }\end{array}$ & $\begin{array}{l}\text { mated } \\
\text { tal } \\
\text { en load } \\
800 \text { feet } \\
\text { oreline } \\
\text { unds) }\end{array}$ & $\begin{array}{r}\text { Estima } \\
\text { tota) } \\
\text { phosphor } \\
\text { from } 1,80 \\
\text { of shor } \\
\text { (poun }\end{array}$ & $\begin{array}{l}\text { ted } \\
\text { us load } \\
\text { eline feet } \\
\text { ds) }\end{array}$ \\
\hline \multicolumn{8}{|l|}{1978} \\
\hline July & 605 & \multicolumn{2}{|c|}{1.09} & \multicolumn{2}{|c|}{38} & \multicolumn{2}{|c|}{0.3} \\
\hline August & 591 & \multicolumn{2}{|c|}{1.06} & \multicolumn{2}{|c|}{37} & \multicolumn{2}{|c|}{.2} \\
\hline September & 637 & \multicolumn{2}{|c|}{1.15} & \multicolumn{2}{|c|}{37} & \multicolumn{2}{|c|}{$<.1$} \\
\hline October & 635 & \multicolumn{2}{|c|}{1.14} & \multicolumn{2}{|c|}{30} & \multicolumn{2}{|c|}{$<.1$} \\
\hline November & 552 & \multicolumn{2}{|c|}{.99} & \multicolumn{2}{|c|}{24} & \multicolumn{2}{|c|}{$<.1$} \\
\hline December & 475 & \multicolumn{2}{|r|}{.86} & \multicolumn{2}{|c|}{21} & \multicolumn{2}{|c|}{$<.1$} \\
\hline \multicolumn{8}{|l|}{1979} \\
\hline January & 339 & \multicolumn{2}{|r|}{.61} & \multicolumn{2}{|c|}{15} & \multicolumn{2}{|c|}{.1} \\
\hline February & 398 & \multicolumn{2}{|c|}{.72} & \multicolumn{2}{|c|}{17} & \multicolumn{2}{|c|}{.2} \\
\hline March & 721 & \multicolumn{2}{|c|}{1.30} & \multicolumn{2}{|c|}{32} & \multicolumn{2}{|c|}{.3} \\
\hline April & 680 & & 1.22 & & 4 & $<$. & \\
\hline May & 635 & & 1.14 & & 2 & $<$. & \\
\hline June & 727 & & 1.31 & & 6 & $<$. & \\
\hline
\end{tabular}

The total nitrogen and total phosphorus from observation wells in the contributing area averaged 6.4 to $0.012 \mathrm{mg} / \mathrm{L}$, respectively. Water produced from the Springvale well field, however, contains less than $1 \mathrm{mg} / \mathrm{L}$ nitrate nitrogen further suggesting that most of the water is derived from a source relatively low in nitrogen, the lake. Total nitrate concentrations in lake water in South and Carling Ponds was less than $0.5 \mathrm{mg} / \mathrm{L}$ (Beskenis and others, 1982) during this period.

The gradient from the lake to the unconsolidated deposits adjacent to the lake indicates that lake water is being induced to seep into the unconsolidated deposits. Water levels in wells NCW-63 and -59 located about 200 and 300 feet, respectively, from the shore of South Pond averaged 0.2 and 0.4 feet, respectively, below lake level from July through December 1978; thereafter, water levels were essentially at lake level in NCW-63 and about 0.15 feet below lake level at NCW-59 until late June 1979 when both wells returned to their July 1978 levels. 
The cone of depression from the Springvale wells extends beneath the lake to the opposite shore which indicates that the lake-bottom sediments in South Pond are relatively impermeable in comparison to the underlying unconsolidated deposits. Most induced infiltration of lake water to the unconsolidated deposits probably occurs along shoreline areas where wave action prevents deposition of relatively impermeable organic silt. The lateral extent of the induced recharge zone along the shoreline is unknown; however, the extent of this zone and volume of seepage are probably greatest during the summer months when pumpage from the Springvale wells is the highest (table 13).

Table 13.--Monthly pumpage of ground water from

Springvale and Evergreen well fields for the

period April 1978 through March 1979

\begin{tabular}{lccc}
\hline & \multicolumn{3}{c}{ Pumpage, in million gallons } \\
\cline { 2 - 4 } Month & $\begin{array}{c}\text { Springvale } \\
\text { well field }\end{array}$ & $\begin{array}{c}\text { Evergreen } \\
\text { well field }\end{array}$ & $\begin{array}{c}\text { Total pumpage } \\
\text { of Springvale } \\
\text { and Evergreen } \\
\text { well fields }\end{array}$ \\
\hline 1978 & & & \\
April & 60.757 & 46.581 & 107.338 \\
May & 73.789 & 51.295 & 125.084 \\
June & 75.943 & 67.154 & 143.097 \\
July & 78.472 & 58.633 & 137.105 \\
August & 72.036 & 56.831 & 128.867 \\
September & 67.789 & 59.790 & 127.579 \\
October & 63.882 & 55.760 & 119.642 \\
November & 61.519 & 60.706 & 122.225 \\
December & 48.909 & 61.566 & 110.475 \\
1979 & & & \\
January & 57.315 & 62.523 & 119.838 \\
February & 53.173 & 55.052 & 108.225 \\
March & 56.738 & 63.644 & 120.382 \\
Totals & 770.322 & 699.535 & $1,469.857$ \\
\hline
\end{tabular}

Although no water-level gradients or chemical analyses are available for the area, Natick's Evergreen. well field (site 4, pl. 1) is located in an analogous situation with respect to the lake and will be included in this discussion. It is difficult to compute what portion of the water pumped by the Springvale and Evergreen municipal wells is induced seepage of lake water and what portion is intercepted ground water. This computation is compounded by the fact that both well fields are located on narrow peninsulas. Even though the physical setting of each well field doesn't correspond to a stream that acts like a constant head recharge boundary to a nearby pumping well, the physical setting is close enough to assume that the landform where each well field is located has water on three sides and the stream, or lake in this situation, acts like a constant head recharge boundary. The major assumption of this approach is that the lake, just like the stream, fully penetrates the aquifer. This assumption isn't quite true because the lake bottom is only 69 and 60 feet below lake level at the deep holes in South and Middle Ponds, respectively, and doesn't fully penetrate the 190 feet of unconsolidated deposits below lake level at nearby site 2. In addition, the lake-bottom sediments seem to have a lower hydraulic conductivity than the unconsolidated deposits of the aquifer. 
If the lake fully penetrated the aquifer, a relation that yields that part of well discharge furnished by a nearby source of recharge (Walton, 1962, pg. 19) would show that the lake provides about 93 percent of the pumped water at both sites. This is based on estimates for each well field of transmissivity of $1,000 \mathrm{ft}^{2} / \mathrm{d}$ (Brackley and Hansen, 1982) for the unconsolidated deposits; a distance from the shoreline to the far thest well of 400 feet at Springvale and 300 feet at Evergreen; the assumption that each well field has been pumping continuously since the last well was added, or 11 years at Springvale and 2 years at Evergreen; and a storage coefficient of 0.2 for the unconsolidated deposits.

However, even though the lake is not fully penetrating and may have some relatively impermeable bottom material away from the shoreline areas, Walton (1962) presents methods to compute the distance between the location of an effective recharge boundary and the pumping well so that the amount of lake derived ground water can be determined. As long as seepage from the lake is sufficient to maintain saturation of the aquifer lying beneath its bottom, the lake surface can be considered to be an established equipotential line and is, therefore, a fixed recharge boundary or limiting condition. This allows Walton's method to be used. The effective recharge boundary is at a greater distance than the distance between the pumping well and the shoreline. It is the mathematical representation of where the recharge boundary seems to act. Unfortunately, the aquifertest data needed for Walton's method are unavailable for the Springvale wells, therefore, the effective distance had to be assumed.

Comparison of water levels in observation wells NCW-63 and -64 at site 3 with lake level shows that ground-water levels are at or slightly below lake level (within 0.1 foot) during January through June and below lake level ( 0.2 to 0.3 foot) during the other months. These wells are close to an area unaffected by pumping and, therefore, are assumed to be the distance to the effective recharge boundary. This distance of 1,600 feet was rounded to 2,000 feet and used to estimate that the Springvale wells divert about 75 percent lake water and intercept about 25 percent ground water.

Analysis of test data collected for the town of Natick during its preliminary evaluation of the Evergreen well field indicates that the wells divert about 93 percent lake water and intercept about 7 percent ground water.

The percentages of lake water pumped by the Springvale and Evergreen wells are only estimates; however, they show the magnitudes of lake water diversion by each well field. The net effect of the Springvale and Evergreen wells is to reduce lake water outflow into Cochituate Brook by the amount pumped (table 13) or 1,470 Mgal during April 1978 through March 1979. Based on the percentage of lake water pumped as opposed to ground water pumped by each well field, 1,228 Mgal of lake water was diverted, while only $242 \mathrm{Mgal}$ of ground water was intercepted by both well fields for this same period.

Another significant source of ground-water pumpage $(250 \mathrm{gal} / \mathrm{min})$ is from well NCW-32 owned by Natick Laboratories located at the end of the peninsula extending into the southern end of South Pond (site 3, pl. 1). This well has lake water on nearly all sides, and therefore, most of the water pumped from this well probably is infiltrated lake water. Very little is thought to be intercepted ground water discharging into South Pond from the peninsula. Water from this well is used for cooling purposes and is discharged into South Pond. This discharge and the load of nutrients it contains is considered neither a gain nor loss to the lake system, just a recycling process, as that fraction of ground water pumped is still discharged to the lake.

In Wayland, the northeast shore of the North Pond is a residential area which is not sewered (site 5, pl. 1). Lithologic logs from observation wells in this area indicate that the area is underlain by 22 feet of sand which rests on a layer of silt and clay of unknown thickness (well WKW-120). At the lake shore, the silt and clay layer extends from just below the elevation of the lake surface to at least 30 feet below (well WKW-117). This clay layer seems to act as a relatively impermeable layer, which creates a perched water table that also may act as the local ground-water divide between Lake Cochituate and Dudley Pond. This divide or highest point on the water table is probably located somewhere between wells WKW-120 and WKW-118, however, the lack of detailed geologic 
information and water-table altitude between these two wells makes it difficult to conclude whether or not this mound is part of the Lake Cochituate/Dudley Pond ground-water divide. Total nitrogen and total phosphorus concentrations from an observation well (WKW-117) at this site averaged 13 and $0.008 \mathrm{mg} / \mathrm{L}$, respectively.

Ground-water gradients at this site are toward the lake all year and an estimated monthly rate of horizontal ground-water flow to North Pond was computed. A value of $152 \mathrm{ft}^{2} / \mathrm{d}$ for transmissivity, estimated from lithologic data at well WKW-117, and the hydraulic gradients and nutrient concentrations of ground water at this well, were assumed to represent average conditions along the 3,000 feet of shoreline labeled $\mathrm{Y}-\mathrm{Y}^{\prime}$ (site 5, pl. 1).

Values of estimated monthly ground-water flow and nutrient loads discharging along the shoreline are shown in table 14. Estimated monthly discharge along the shoreline during the period July 1978-June 1979 ranged from 3.15 to 3.58 Mgal per month with an average rate of $3.43 \mathrm{Mgal}$ per month. These data show much less variation in monthly flow than site 2. For the same period, the estimated monthly load of total nitrogen ranged from 180 to 490 pounds per month with an average rate of 350 pounds per month. Also, the estimated load of total phosphorus ranged from 0.1 to 0.4 pound per month. For this entire period, the total estimated ground-water and nutrient discharges to the lake at site 5 were estimated to be $41.1 \mathrm{Mgal}$ of water, 4,200 pounds of nitrogen, and 2.3 pounds of phosphorus. Assuming that the 41.1 Mgal of ground water is recharged through a rectangular area 3,000 feet long (length of shoreline) by 1,000 feet wide (average distance between shoreline and divide) an average recharge rate of about 22 inches per year would be required. This estimate is in close agreement with estimated recharge rates for sand and gravel aquifers in Massachusetts (Guswa and LeBlanc, 1981).

The area around site 5 is entirely residential with onlot disposal of domestic wastes; whereas, the area around site 2 is sewered. The volume of ground-water discharge from the unconsolidated deposits at site 5 is about 2 times greater and the average total nitrogen concentration is about 4 times greater than at site 2 reflecting water recharge and nutrient material from the onlot disposal systems. Although the total nitrogen load discharging from site 5 exceeds site 2 by a factor of seven per year per unit of shoreline, phosphorus loads per unit of shoreline are about equal ( 0.77 to 0.83 pound per year per 1,000 feet of shoreline at sites 2 and 5, respectively). This indicates that the phosphorus load from the onlot disposal systems is being retained and not transported by ground water. The inorganic phosphorus is probably removed by being (1) sorbed onto clays or ferric hydroxide precipitate; (2) co-precipitated with iron, manganese, and carbonates; or (3) precipitated as apatite or ferric phosphate.

The most complex ground-water investigation site is a sewered residential area at the north end of North Pond (site 6, pl. 1). Water levels and lithologic information collected in this area indicate that there are two distinct ground-water flow systems separated by a clay layer of varying thickness (fig. 10). Ground water in the aquifer above the clay layer flows into North Pond; and, ground water in the aquifer below the clay layer flows aw ay from the lake, possibly discharging into the Sudbury River.

At site 6 , water levels in observation wells $F 1 W-84$ and -87 that are screened in the unconsolidated aquifer and the lake levels indicate that ground water in the upper aquifer discharges into the lake all year (fig. 10). A continuous record of water levels in well F1 W-87 indicates that the water table in the vicinity of this well is strongly affected by a daily periodic discharge to the ground water which causes the water level to peak at about midday. Because of this, the location of the ground-water divide for the upper aquifer is undetermined and the quantity of ground water flowing through the site would not be due to precipitation alone. However, the divide is thought to be slightly south of the surfacewater divide, probably in the vicinity of Old Connecticut Path (State Route 126). Ground water on the south side of the ground-water divide flows into Lake Cochituate, whereas water on the north side of the ground-water divide flows to the Sudbury River. Because of the complicated water discharge in this area, accurate water-level gradient data needed to compute ground-water flow were not available. 
Table 14.-Estimated monthly runoff and nutrient loads entering Nor th Pond from ground-water sources at site 5

\begin{tabular}{|c|c|c|c|c|c|c|c|}
\hline \multirow[b]{2}{*}{$\begin{array}{l}\text { Local well } \\
\text { number/average } \\
\text { depth below } \\
\text { water table } \\
\text { to center of } \\
\text { well screen } \\
\text { (feet) }\end{array}$} & \multirow[b]{2}{*}{$\begin{array}{l}\text { Type of } \\
\text { statistic }\end{array}$} & \multicolumn{6}{|c|}{ Concentration, in milligrams per liter } \\
\hline & & $\begin{array}{l}\text { Total } \\
\text { ammonia } \\
\text { nitrogen } \\
\text { (as ni- } \\
\text { trogen) }\end{array}$ & $\begin{array}{l}\text { Total } \\
\text { nitrite } \\
\text { plus } \\
\text { nitrate } \\
\text { nitrogen } \\
\text { (as ni- } \\
\text { trogen) }\end{array}$ & $\begin{array}{l}\text { Total } \\
\text { organic } \\
\text { nitrogen } \\
\text { (as ni- } \\
\text { trogen) }\end{array}$ & $\begin{array}{l}\text { Total } \\
\text { nitrogen } \\
\text { (as ni- } \\
\text { trogen) }\end{array}$ & $\begin{array}{l}\text { Total } \\
\text { ortho- } \\
\text { phosphate } \\
\text { phos- } \\
\text { phorus } \\
\text { (as phos- } \\
\text { phorus) }\end{array}$ & $\begin{array}{l}\text { Total } \\
\text { phos- } \\
\text { phorus } \\
\text { (as } \\
\text { phos- } \\
\text { phorus) }\end{array}$ \\
\hline \multirow[t]{2}{*}{ WKW-117/0.8 } & $\begin{array}{l}\text { Maximum } \\
\text { Average } \\
\text { Minimum } \\
\text { No. of }\end{array}$ & $\begin{array}{r}0.56 \\
.20 \\
.00\end{array}$ & $\begin{array}{l}17 \\
12 \\
5.4\end{array}$ & $\begin{array}{r}0.90 \\
.28 \\
.00\end{array}$ & $\begin{array}{l}17 \\
13 \\
6.3\end{array}$ & $\begin{array}{r}0.003 \\
.002 \\
.000\end{array}$ & $\begin{array}{r}0.014 \\
.008 \\
.002\end{array}$ \\
\hline & analyses & 4 & 4 & 4 & 4 & 4 & 4 \\
\hline
\end{tabular}

Ground-water runoff and nutrient loads

\begin{tabular}{lcccc}
\hline Month & $\begin{array}{c}\text { Estimated } \\
\text { flow per foot } \\
\text { of shoreline } \\
\text { (gallons) }\end{array}$ & $\begin{array}{c}\text { Estimated flow } \\
\text { from 3,000 feet } \\
\text { of shoreline } \\
\text { (million gallons) }\end{array}$ & $\begin{array}{c}\text { Estimated total } \\
\text { nitrogen load } \\
\text { from 3,000 feet } \\
\text { of shoreline } \\
\text { (pounds) }\end{array}$ & $\begin{array}{c}\text { Estimated total } \\
\text { phosphorus load } \\
\text { from 3,000 feet } \\
\text { of shoreline } \\
\text { (pounds) }\end{array}$ \\
\hline s78 & & & & \\
July & 1,134 & 3.40 & 400 & 0.3 \\
August & 1,134 & 3.40 & 380 & .3 \\
September & 1,113 & 3.34 & 360 & .4 \\
October & 1,162 & 3.49 & 470 & .1 \\
November & 1,124 & 3.37 & 480 & .1 \\
December & 1,157 & 3.47 & 490 & .1 \\
1979 & & & & .1 \\
January & 1,153 & 3.46 & 490 & .1 \\
February & 1,051 & 3.15 & 340 & .2 \\
March & 1,185 & 3.55 & 190 & .2 \\
April & 1,151 & 3.45 & 180 & .2 \\
May & 1,192 & 3.58 & 190 & .2 \\
June & 1,158 & 3.47 & 180 & \\
\hline
\end{tabular}




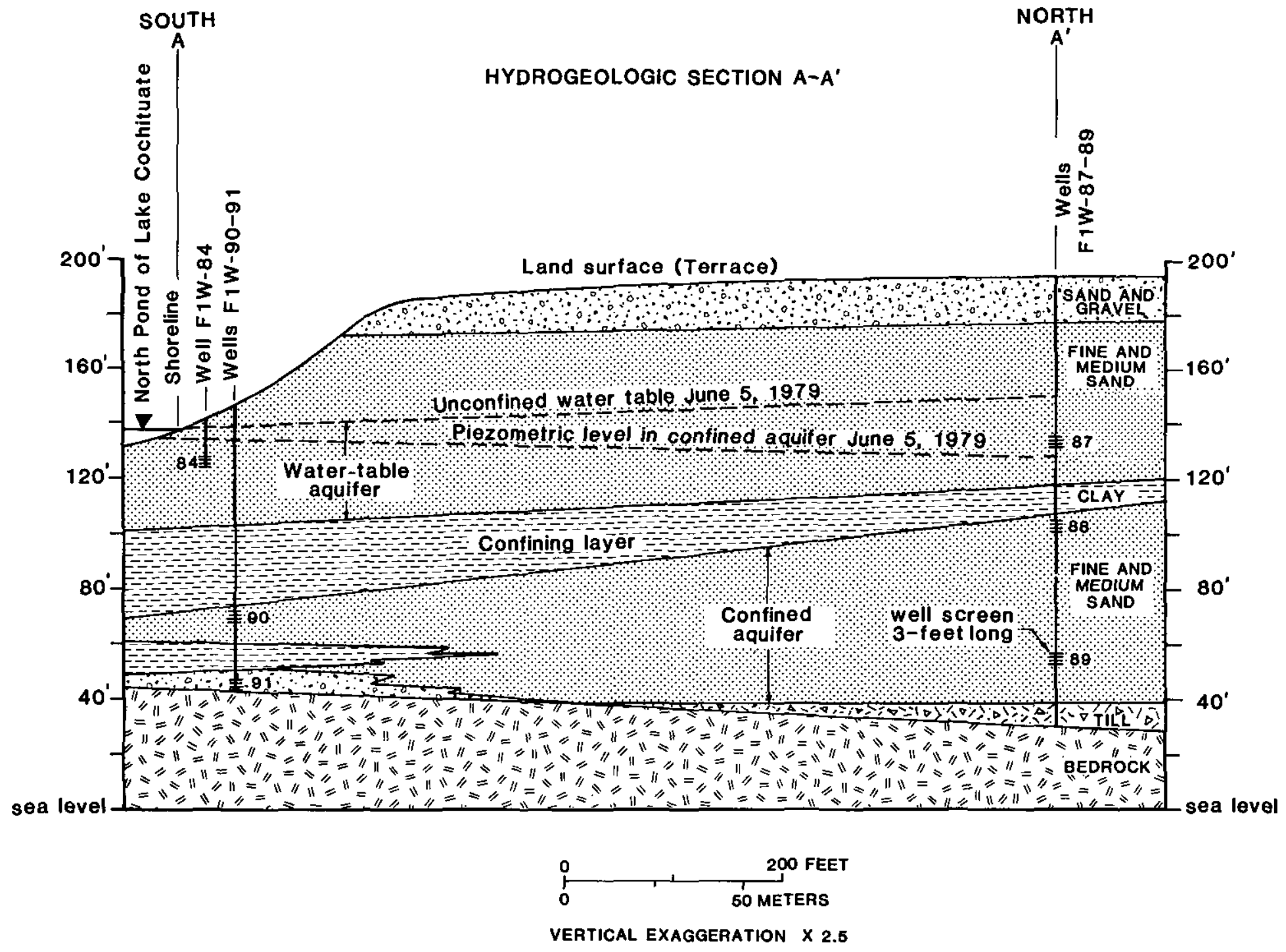

Figure 10.--Hydrogeologic section $A-A^{\prime}$ through observation wells $F 1 W-84,-90$, and -91 , and $F 1 W-87$ through -89 at site 6 . 
The total nitrogen and total phosphorus concentrations from an observation well (F1W-84) at this site averaged $17 \mathrm{mg} / \mathrm{L}$ and $0.015 \mathrm{mg} / \mathrm{L}$, respectively. The average total nitrogen concentration of ground water in the vicinity of this well located 10 feet from the edge of North Pond is the highest found at any site. This nitrogen concentration is high considering the area upgradient of this well is a sewered residential area. Possibly, this area may contain a few septic systems or has leaking sanitary sewers. Regardless of the nutrient source, this nitrogen-rich ground water flows into Lake Cochituate.

Flow in the confined aquifer below the clay at site 6 is to the north from North Pond toward the Sudbury River. Water levels in well F1W-90 located adjacent to the pond averaged 5.6 feet higher than water levels in well F1W-88 located about 650 feet nor th of the pond. In addition, water levels in F1W-90 averaged 4.1 feet below lake level indicating it should be receiving water leaking from North Pond and the overlying unconfined aquifer.

Ground water in the unconsolidated deposits in the vicinity of the west end of Dudley Pond and the north end of Nor th Pond (site 7, pl. 1) moves generally in a northwest direction receiving some recharge from Dudley and North Ponds. Monthly water levels in two wells, located about 10 feet west of Dudley Pond, average about 6 feet below the water level in Dudley Pond. Both wells, WKW-124 and -122, have nearly identical water levels even though they are screened 23 and 60 feet below land surface, respectively. The identical water levels in wells WKW-124 and -122 indicate that ground-water flow is nearly horizontal. The horizontal flow suggests that the unconsolidated deposits are receiving very little seepage from Dudley Pond. In addition, the sharp difference in water levels between Dudley Pond and these wells also indicates that, in this area, the pond is above the water table and that the hydraulic conductivity of the pond's bottom sediments is very low and is limiting the seepage of pond water. Also, monthly water levels in well WKW-119 located about 200 feet north of North Pond averaged 7.5 feet below the water level in North Pond. This difference in water levels between North Pond and well WKW-119 indicates that the unconsolidated deposits in this area should be receiving some water leaking from North Pond.

Ground water in this area contains low concentrations of both total nitrogen and total phosphorus. Chemical analyses of two water samples collected from each well at the west end of Dudley Pond (WKW-121 through -124) the north end of North Pond (WKW-119) show that the average total nitrogen and total phosphorus concentrations are 0.32 and $0.006 \mathrm{mg} / \mathrm{L}$, respectively.

A part of the ground water moving north toward the Sudbury River from the area around North Pond may be intercepted by Framingham's municipal well field (F1W-41 through -43). These wells are located north of and about half way between the Sudbury River and the north shore of North Pond. During the period July 1978 through June 1979, this well field wasn't operated.

Selected recharge rates to the ground-water reservoir were used to compute a probable range of estimated yearly ground-water flow from the $2.70 \mathrm{mi}^{2}$ (16 percent) of ungaged unconsolidated deposits that drain directly into Lake Cochituate. This $2.70 \mathrm{mi}^{2}$ is based on the surface-water drainage divide which is assumed to be equivalent to the ground-water drainage divide. Over the long term, ground-water recharge is assumed to equal ground-water discharge to the lake; however, a portion of the ground water in these unconsolidated deposits is being withdrawn by the Springvale and Evergreen well fields. In addition, recharge to each well field also occurs by way of induced seepage of lake water. Therefore, to account for the diversion of ground water by these well fields, the estimated yearly ground-water flow to the lake from the $2.70 \mathrm{mi}^{2}$ of unconsolidated deposits adjacent to the lake will have to be reduced by $242 \mathrm{Mgal}$ (see page 44). Also, a small portion of the unconsolidated deposits around the north end of North Pond may be receiving exfiltration from the lake, as well as a small portion of the unconsolidated deposits just north and east of well WKW-118 may be contributing ground water across the surface-water divide to the Dudley Pond basin. The direction of ground-water flow in these 
areas is uncertain and the large vertical gradients in the unconsolidated deposits along the northern edge of North Pond indicate that the rate of exfiltration from the lake is relatively small, therefore, it is neglected in the following discussions.

Analysis of the Pegan Brook daily streamflow data for April 1978 through March 1979 by hydrographic separation techniques shows that ground-water discharge from the Pegan Brook basin was 14.1 inches. This agrees well with a yearly recharge rate of about 14 inches calculated for site 2: Accordingly, recharge of ground water in the Pegan Brook basin is somewhere around 14 to 15 inches of water. Applying 15 inches of recharge to the $2.70 \mathrm{mi}^{2}$ of unconsolidated deposits adjacent to the lake yields $704 \mathrm{Mgal}$ of yearly ground-water flow to Lake Cochituate, assuming zero pumpage of both well fields.

Franke and McClymonds (1972) report that the annual long-term recharge rate for Long Island, New York, equals approximately one-half of the annual precipitation. For the period, April 1978 through March 1979, precipitation in Framingham, Mass., totaled 45.09 inches (see "Precipitation" section) and was only 1.81 inches above average. Applying one-half of the precipitation (22.55 inches) as recharge to the $2.70 \mathrm{mi}^{2}$ of unconsolidated deposits adjacent to the lake yields $1,058 \mathrm{Mgal}$ of yearly ground-water flow to Lake Cochituate, assuming zero pumpage of both well fields. This later recharge rate (22.55 inches) is similar to the one computed for site 5 (22 inches) which, like some other sites around the lake, receives additional recharge from onlot disposal systems.

The range of estimated yearly ground-water flow to Lake Cochituate, corrected for pumpage by the Springvale and Evergreen well fields, ranges from 462 to $816 \mathrm{Mgal}$ from the $2.70 \mathrm{mi}^{2}$ of unconsolidated deposits adjacent to the lake. This range was determined by subtracting the amount of ground water intercepted and diverted for municipal supply ( $242 \mathrm{Mgal}$ ) from the estimated yearly ground-water flow from the $2.70 \mathrm{mi}^{2}$ of unconsolidated deposits (704 and $1058 \mathrm{Mgal}$ ).

A range in nutrient loads was computed by multiplying the range of yearly groundwater flow to the lake ( 462 to $816 \mathrm{Mgal}$ ) by the average total nitrogen and total phosphorus concentrations found in ground water adjacent to the lake. Nutrient concentrations in wells installed at various shoreline locations around the lake were used to compute the average nutrient concentrations. These data are considered representative of sites where ground water discharges to the lake such as sites $1,2,5$, and 6 and sites where ground water is intercepted by municipal wells such as sites 3 and 4 . Nutrient data were averaged for each site except site 4 , and then were averaged for all those sites (table 15).

Table 15.-Average concentrations of total nitrogen and total phosphorus in ground water at selected sites adjacent to Lake Cochituate

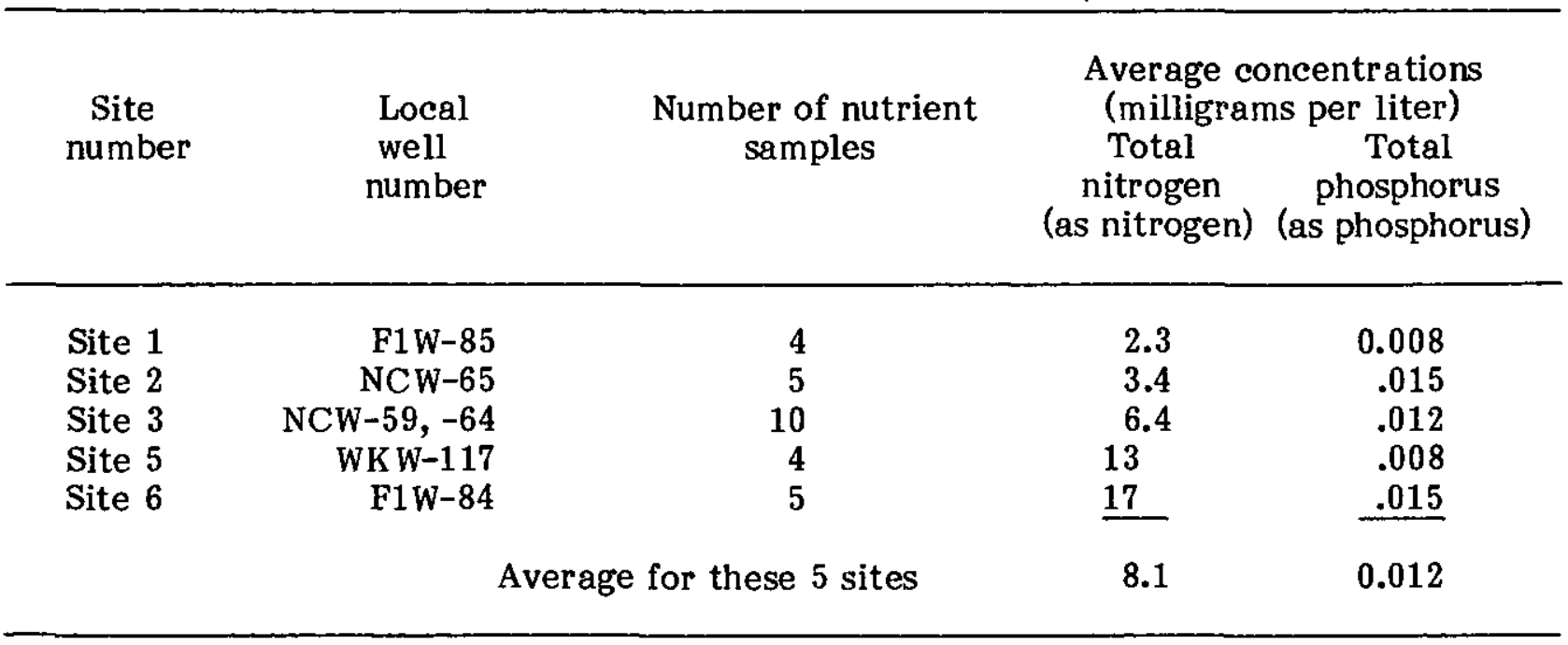


Applying the average concentrations of nitrogen $(8.1 \mathrm{mg} / \mathrm{L})$ and phosphorus $(0.012 \mathrm{mg} / \mathrm{L})$ in ground water adjacent to the lake to the 462 and $816 \mathrm{Mgal}$ of estimated yearly ground-water flow to the lake yields between 31,000 and 55,000 pounds of nitrogen and between 46 and 82 pounds of phosphorus, respectively, moving into the lake.

\section{Precipitation}

Precipitation (wet) from the atmosphere contributes nitrogen and phosphorus as well as water directly to the surface of Lake Cochituate during each precipitation event. The total volume of precipitation, in million gallons per month, that fell to the surface of the lake is listed earlier in this report (table 5). To estimate the probable nutrient load from this source two storms were sampled (table 16). Using the total volume of precipitation (721 Mgal) for the period April 1978 through March 1979 and assuming that the average concentrations of total nitrogen and total phosphorus of the two composite samples (table 16) were representative for that 1 year period, 4,000 pounds of total nitrogen and 78 pounds of total phosphorus were estimated to have been deposited to the lake's surface.

In addition to precipitation contributing nutrients to the lake, dry-fallout between precipitation events adds nutrients to the lake's surface. Bulk precipitation is the term that is applied to measurements of both wet precipitation and dry fallout between wetprecipitation events. If the average total nitrogen and phosphorus concentrations found in bulk precipitation deposited on the Great Lakes basin between 1969 and 1976 (Kuntz, 1981) are applied to Lake Cochituate, then the estimated nutrient loads to Lake Cochituate from bulk precipitation would be about double that for wet-precipitation or 8,000 pounds of total nitrogen and 160 pounds of total phosphorus.

The reader should view the nutrient concentrations and loads presented in this section as relative values and not as absolute values because the loads are based on very limited or transferred data. However, these estimates are given for comparison with nutrient loads from all inputs to Lake Cochituate to determine the relative magnitude of nutrient contributions from the atmosphere.

Table 16.-Nutrient concentrations, water volumes, and estimated nutrient loads entering Lake Cochituate from two precipitation events at National Weather Service Station in Framingham

\begin{tabular}{|c|c|c|c|c|c|c|c|}
\hline \multirow[b]{2}{*}{$\begin{array}{l}\text { Date of } \\
\text { precipitation } \\
\text { event }\end{array}$} & \multirow[b]{2}{*}{$\begin{array}{l}\text { Total } \\
\text { water } \\
\text { from } \\
\text { event } \\
\text { (inches/ } \\
\text { million } \\
\text { gallons) }\end{array}$} & \multicolumn{6}{|c|}{ Nutrient species } \\
\hline & & $\begin{array}{l}\text { Total } \\
\text { ammonia } \\
\text { nitrogen } \\
\text { (as ni- } \\
\text { trogen) }\end{array}$ & $\begin{array}{l}\text { Total } \\
\text { nitrite } \\
\text { plus } \\
\text { nitrate } \\
\text { nitrogen } \\
\text { (as ni- } \\
\text { trogen) }\end{array}$ & $\begin{array}{l}\text { Total } \\
\text { organic } \\
\text { nitrogen } \\
\text { (as ni- } \\
\text { trogen) }\end{array}$ & $\begin{array}{l}\text { Total } \\
\text { nitrogen } \\
\text { (as ni- } \\
\text { trogen) }\end{array}$ & $\begin{array}{l}\text { Total } \\
\text { ortho- } \\
\text { phosphate } \\
\text { phos- } \\
\text { phorus } \\
\text { (as phos- } \\
\text { phorus) }\end{array}$ & $\begin{array}{l}\text { Total } \\
\text { phos- } \\
\text { phorus } \\
\text { (as } \\
\text { phos- } \\
\text { phorus) }\end{array}$ \\
\hline & & \multicolumn{6}{|c|}{ Estimated load, in pounds } \\
\hline $12 / 8-9 / 78$ & $1.47 / 23.5$ & 16 & 41 & 0 & 57 & $<1$ & 4 \\
\hline $4 / 26-27 / 79$ & $2.15 / 34.4$ & 23 & 26 & 250 & 300 & $<1$ & 2 \\
\hline \multicolumn{2}{|c|}{ Type of statistic } & \multicolumn{6}{|c|}{ Concentration, in milligrams per liter } \\
\hline \multicolumn{2}{|c|}{ Maximum of both events } & 0.08 & 0.21 & 0.87 & 1.04 & 0.001 & 0.019 \\
\hline \multirow{2}{*}{\multicolumn{2}{|c|}{$\begin{array}{l}\text { Minimum of both events } \\
\text { Number of samples }\end{array}$}} & .08 & .09 & .00 & .29 & .001 & .007 \\
\hline & & 2 & 2 & 2 & 2 & 2 & 2 \\
\hline
\end{tabular}




\section{ESTIMATED WATER AND NUTRIENT OUTFLOWS FROM LAKE COCHITUATE}

\section{Surface Outlet}

The level of the lake (fig. 11) is maintained within a narrow range of elevations by the Massachusetts Division of Forest and Parks because the lake is used for recreational purposes. Regulation of the lake's level is accomplished by altering the flow from the lake into Cochituate Brook at the outlet's uppermost dam. This is done either by adding/deleting boards to the dam or opening/closing a sluice gate at the south end of the dam. The flow of water from the lake varies directly with the head of water over this dam. Generally, if more water is allowed to flow from the lake than enters, the level of the lake will fall. Conversely, if less water is allowed to flow from the lake than enters, the level of the lake will rise. In the summer, when inflow from the lake's tributaries and adjacent unconsolidated deposits is the least and evaporation from the lake's surface is the greatest, sometimes flow from the lake has to be completely stopped in an attempt to maintain the lake level. This situation occured in September and in early October 1978. At those times, the only flow to Cochituate Brook from the lake was from seepage at the dam.

There is a direct relationship between the volume of flow and nutrient loads leaving the lake (table 17). Both the volume of flow and the nutrient loads are generally the greatest during periods of snowmelt or during periods of intense rainfall in the fall, winter, or spring when evapotranspiration is minimal.

To accurately compare the volume of inflow to the volume of outflow the level of the reservoir must be the same at the beginning of the accounting period (April 1, 1978) as at the end (March 31, 1979). To correct the volume of outflow for the observed 1-foot drop in lake level (fig. 11) between the beginning and end of the accounting period $192 \mathrm{Mgal}$ of water was subtracted from the actual observed flow from the lake, leaving 7,294 Mgal.

Lake Cochituate's four ponds have a combined volume of approximately 4,500 Mgal (see "Surface-water drainage system" section). Based on this volume and the adjusted volume of runoff leaving the lake $(7,294 \mathrm{Mgal})$ in a 1 year period, it would take, theoretically, a little over 7 months to fill the lake. This 7 -month period is also referred to as the lake's flushing rate or retention time. Each of these terms is determined by assuming that the volume of runoff is apportioned equally over the year and that there is no short circuiting of flow in the lake's water column due to thermal stratification in each pond. However, runoff into the lake in the late fall, winter, and early spring is usually greater than at other times of the year, and thermal stratification does occur in these ponds during summer months (Beskenis and others, 1982).

\section{Evaporation}

Monthly evaporation from a surface-water body varies from near zero in the winter months to a maximum in the summer months. A plot of the individual monthly rates of evaporation has the appearance of a bell-shaped curve. Monthly evaporation rates were not measured at Lake Cochituate; however, an annual evaporation rate of about 28 inches of water was estimated for the surface of Lake Cochituate (Knox and Nordenson, 1955). Applying the annual rate of evaporation to the $0.92 \mathrm{mi}^{2}$ of the lake's surface shows that Lake Cochituate is losing approximately $450 \mathrm{Mgal} / \mathrm{yr}$ of water to the atmosphere. However, this water loss probably transports little if any nutrients from the lake's water surface. 
DAILY STAGE OF LAKE COCHITUATE

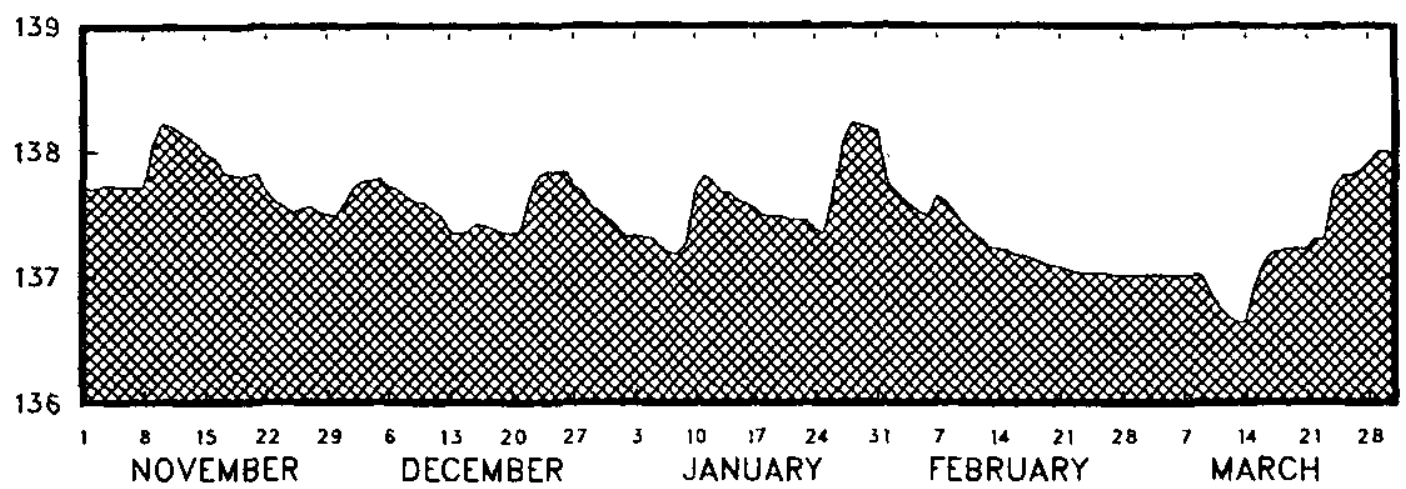

1977

1978

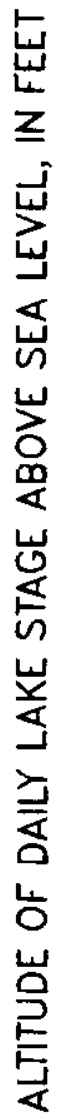
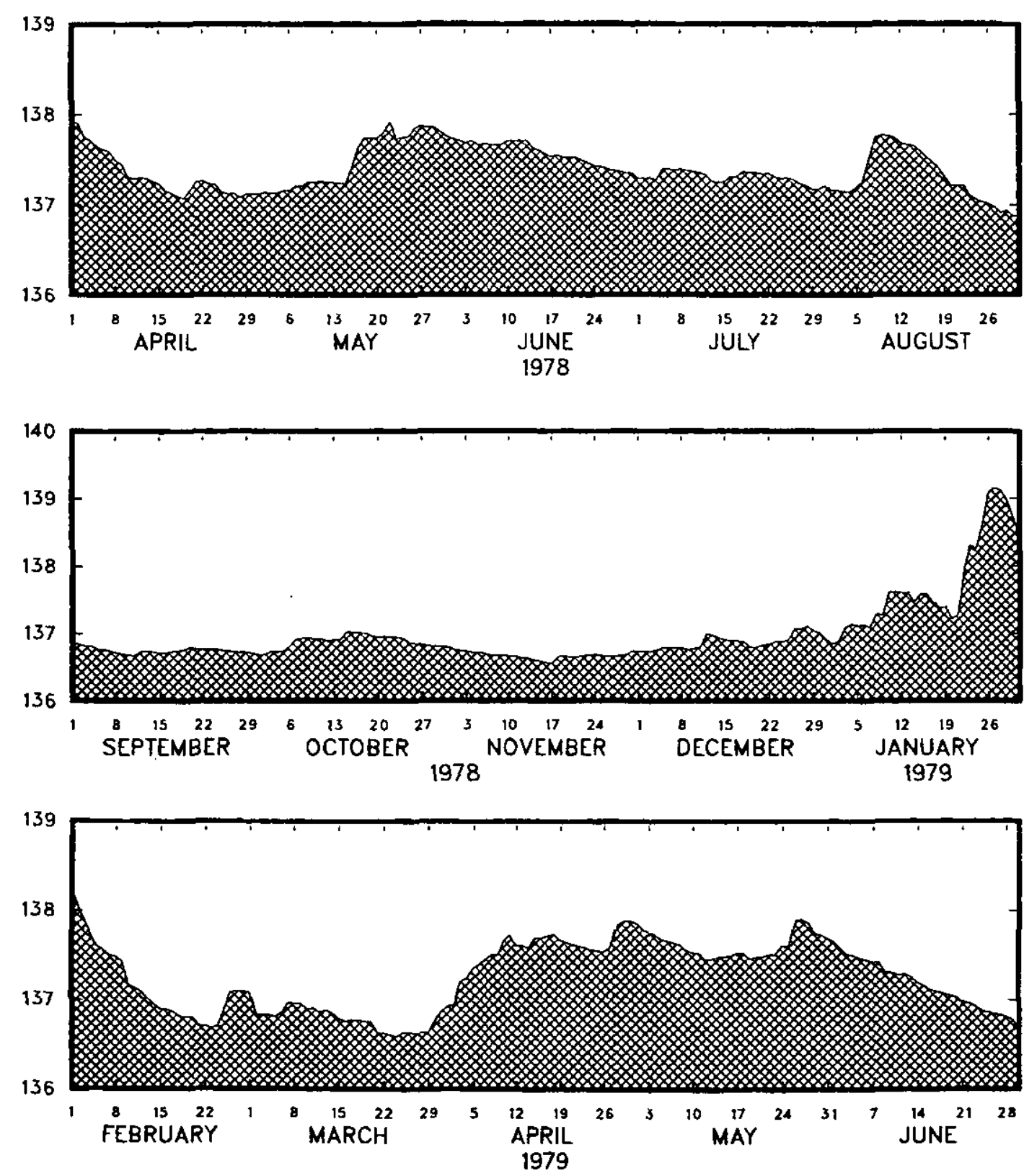

Figure 11.--Daily water levels in North Pond, Lake Cochituate, at the Cochituate aqueduct intake structure (Data from Metropolitan District Commission). 
Table 17.--Nutrient concentrations, volume of monthly runoff, and estimated nutrient loads leaving Lake Cochituate at its surface outlet

\begin{tabular}{|c|c|c|c|c|c|c|c|}
\hline \multirow[b]{2}{*}{$\begin{array}{l}\text { Type of } \\
\text { statistic }\end{array}$} & & \multicolumn{6}{|c|}{ Nutrient species } \\
\hline & & $\begin{array}{l}\text { Total } \\
\text { ammonia } \\
\text { nitrogen } \\
\text { (as ni- } \\
\text { trogen) }\end{array}$ & $\begin{array}{l}\text { Total } \\
\text { nitrite } \\
\text { plus } \\
\text { nitrate } \\
\text { nitrogen } \\
\text { (as ni- } \\
\text { trogen) }\end{array}$ & $\begin{array}{l}\text { Total } \\
\text { organic } \\
\text { nitrogen } \\
\text { (as ni- } \\
\text { trogen) }\end{array}$ & $\begin{array}{l}\text { Total } \\
\text { nitrogen } \\
\text { (as ni- } \\
\text { trogen) }\end{array}$ & $\begin{array}{l}\text { Total } \\
\text { ortho- } \\
\text { phosphate } \\
\text { phos- } \\
\text { phorus } \\
\text { (as phos- } \\
\text { phorus) }\end{array}$ & $\begin{array}{l}\text { Total } \\
\text { phos- } \\
\text { phorus } \\
\text { (as } \\
\text { phos- } \\
\text { phorus) }\end{array}$ \\
\hline & & \multicolumn{6}{|c|}{ Concentration, in milligrams per liter } \\
\hline $\begin{array}{l}\text { Maximum } \\
\text { Average } \\
\text { Minimum }\end{array}$ & & $\begin{array}{r}0.18 \\
.05 \\
.00\end{array}$ & $\begin{array}{r}0.64 \\
.18 \\
.00\end{array}$ & $\begin{array}{r}0.64 \\
.43 \\
.10\end{array}$ & $\begin{array}{l}1.0 \\
.66 \\
.31\end{array}$ & $\begin{array}{r}0.005 \\
.001 \\
.000\end{array}$ & $\begin{array}{r}0.045 \\
.019 \\
.000\end{array}$ \\
\hline No. of analyses & & 22 & 22 & 22 & 22 & 22 & 22 \\
\hline $\begin{array}{l}\text { Month } \\
\text { and } \\
\text { year }\end{array}$ & $\begin{array}{l}\text { Runoff } \\
\text { (million } \\
\text { gallons) }\end{array}$ & \multicolumn{6}{|c|}{$\begin{array}{l}\text { Estimated load } \\
\text { (pounds) }\end{array}$} \\
\hline \multicolumn{8}{|l|}{1977} \\
\hline $\begin{array}{l}\text { November } \\
\text { December }\end{array}$ & $\begin{array}{r}782.7 \\
1,252.6\end{array}$ & $\begin{array}{r}350 \\
1,500\end{array}$ & $\begin{array}{r}380 \\
1,300\end{array}$ & $\begin{array}{l}3,700 \\
4,800\end{array}$ & $\begin{array}{l}4,400 \\
7,500\end{array}$ & $\begin{array}{l}0 \\
0\end{array}$ & $\begin{array}{l}140 \\
280\end{array}$ \\
\hline \multicolumn{8}{|l|}{1978} \\
\hline $\begin{array}{l}\text { January } \\
\text { February } \\
\text { March } \\
\text { April } \\
\text { May } \\
\text { June } \\
\text { July } \\
\text { August } \\
\text { September } \\
\text { October } \\
\text { November } \\
\text { December }\end{array}$ & $\begin{array}{r}1,553.1 \\
774.9 \\
1,267.4 \\
1,255.8 \\
475.7 \\
195.1 \\
54.7 \\
311.1 \\
35.1 \\
95.7 \\
101.1 \\
363.7\end{array}$ & $\begin{array}{r}1,600 \\
710 \\
960 \\
840 \\
68 \\
16 \\
9 \\
73 \\
9 \\
1 \\
42 \\
360\end{array}$ & $\begin{array}{r}4,700 \\
3,100 \\
6,100 \\
6,700 \\
1,800 \\
620 \\
91 \\
86 \\
1 \\
9 \\
17 \\
200\end{array}$ & $\begin{array}{r}5,600 \\
2,700 \\
3,600 \\
3,000 \\
1,700 \\
740 \\
200 \\
1,200 \\
150 \\
450 \\
440 \\
1,700\end{array}$ & $\begin{array}{r}12,000 \\
6,500 \\
11,000 \\
11,000 \\
3,500 \\
1,400 \\
300 \\
1,400 \\
160 \\
460 \\
500 \\
2,300\end{array}$ & $\begin{array}{r}0 \\
0 \\
13 \\
21 \\
1 \\
0 \\
0 \\
0 \\
<1 \\
<1 \\
2 \\
2\end{array}$ & $\begin{array}{r}290 \\
130 \\
190 \\
180 \\
53 \\
5 \\
4 \\
32 \\
4 \\
10 \\
19 \\
100\end{array}$ \\
\hline \multicolumn{8}{|l|}{1979} \\
\hline $\begin{array}{l}\text { January } \\
\text { February } \\
\text { March } \\
\text { April } \\
\text { May }\end{array}$ & $\begin{array}{r}2,333.9 \\
1,033.5 \\
1,230.1 \\
592.0 \\
782.0\end{array}$ & $\begin{array}{r}1,700 \\
460 \\
300 \\
0 \\
65\end{array}$ & $\begin{array}{l}2,600 \\
2,100 \\
3,100 \\
1,600 \\
1,600\end{array}$ & $\begin{array}{l}9,000 \\
3,300 \\
5,100 \\
2,500 \\
2,400\end{array}$ & $\begin{array}{r}13,000 \\
5,900 \\
8,500 \\
4,100 \\
4,000\end{array}$ & $\begin{array}{r}5 \\
11 \\
0 \\
5 \\
13\end{array}$ & $\begin{array}{r}570 \\
200 \\
330 \\
190 \\
98\end{array}$ \\
\hline $\begin{array}{l}\text { April } 1978- \\
\quad \text { March } 1979\end{array}$ & $7,485.5$ & 3,900 & 17,000 & 27,000 & 48,000 & 42 & 1,500 \\
\hline
\end{tabular}




\section{SUMMARY AND CONCLUSIONS}

The rate or degree of eutrophication of a lake is partly dependent on the amount and ratio of nutrients entering the lake at present and partly dependent on the amount and ratio of nutrients that have entered the lake in the past. Some of the nutrients that previously entered the lake have settled out of suspension and are deposited in the lake's bottom sediments. Part of the nutrients in these bottom sediments are available for recycling within the lake's water column, particularly, during the spring and fall turnovers. These nutrients are then available for biological activity, and are continually augumented by the inflow of nutrients from surface- and ground-water sources as well as precipitation. Therefore, nutrient levels in the water entering the lake over a period of time do affect the nutrient levels in the lake and in the water leaving the lake. However, because the flushing rate of Lake Cochituate's four-pond system is approximately 7 months, nutrient inflow from Fisk Pond on any given month, especially in the summer, is not related to nutrient outflow during that same month for it is not the same parcel of water.

One step toward controlling the eutrophication within a lake is to quantify the nutrient loads discharged to the lake from each source to determine their relative magnitudes with respect to the total input. Then judgments can be made as to whether: (1) These nutrient loads will cause or sustain eutrophic conditions within a lake; (2) it is feasible or not to control the nutrient loads from a particular source; and (3) that control will diminish the eutrophication problem.

Estimates of water volumes and total nitrogen and total phosphorus loads entering and leaving Fisk Pond and Lake Cochituate from surface water, ground water, precipitation, and evaporation are summarized in the following schematic diagrams (water volumes, fig. 12, and nutrient loads, fig. 13) for the period April 1978 through March 1979. In addition, a breakdown of the various nutrient loads entering Fisk Pond and Lake Cochituate from each surface-water source are also summarized in table 18 for that same period.

Table 18.--Summary of estimated nutrient loads entering Fisk Pond and Lake Cochituate from surface-water sources for the period April 1978 through March 1979

\begin{tabular}{|c|c|c|c|c|c|c|}
\hline \multirow[b]{2}{*}{ Source } & \multicolumn{6}{|c|}{ Estimated load, in pounds } \\
\hline & $\begin{array}{l}\text { Total } \\
\text { ammonia } \\
\text { nitrogen } \\
\text { (as ni- } \\
\text { trogen) }\end{array}$ & $\begin{array}{l}\text { Total ni- } \\
\text { trite plus } \\
\text { nitrate } \\
\text { nitrogen } \\
\text { (as ni- } \\
\text { trogen) }\end{array}$ & $\begin{array}{l}\text { Total } \\
\text { organic } \\
\text { nitrogen } \\
\text { (as ni- } \\
\text { trogen) }\end{array}$ & $\begin{array}{l}\text { Total } \\
\text { nitrogen } \\
\text { (as ni- } \\
\text { trogen) }\end{array}$ & $\begin{array}{l}\text { Total } \\
\text { ortho- } \\
\text { phosphate } \\
\text { phosphorus } \\
\text { (as phos- } \\
\text { phorus) }\end{array}$ & $\begin{array}{l}\text { Total } \\
\text { phos- } \\
\text { phorus } \\
\text { (as phos- } \\
\text { phorus) }\end{array}$ \\
\hline Beaverdam Brook & 2,700 & 11,000 & 15,000 & 28,000 & 330 & 1,700 \\
\hline Course Brook & 990 & 4,400 & 6,300 & 12,000 & 160 & 480 \\
\hline \multicolumn{7}{|l|}{ Ungaged area drain- } \\
\hline ing into Fisk Pond & 100 & 2,100 & 790 & 3,000 & 14 & 140 \\
\hline Fisk Pond outlet & 3,400 & 13,000 & 21,000 & 38,000 & 380 & 2,000 \\
\hline Pegan Brook & 130 & 3,100 & 1,000 & 4,300 & 17 & 180 \\
\hline Snake Brook & 260 & 7,100 & 2,900 & 10,000 & 55 & 300 \\
\hline $\begin{array}{l}\text { Ungaged land area } \\
\text { draining directly }\end{array}$ & & & & & & \\
\hline into Lake Cochituate & 360 & 7,600 & 2,800 & 11,000 & 55 & 490 \\
\hline \multicolumn{7}{|l|}{ Total loads entering } \\
\hline Lake Cochituate & 4,100 & 31,000 & 28,000 & 63,000 & 510 & 3,000 \\
\hline
\end{tabular}


WATER VOLUMES

\section{April 1978 through March 1979}

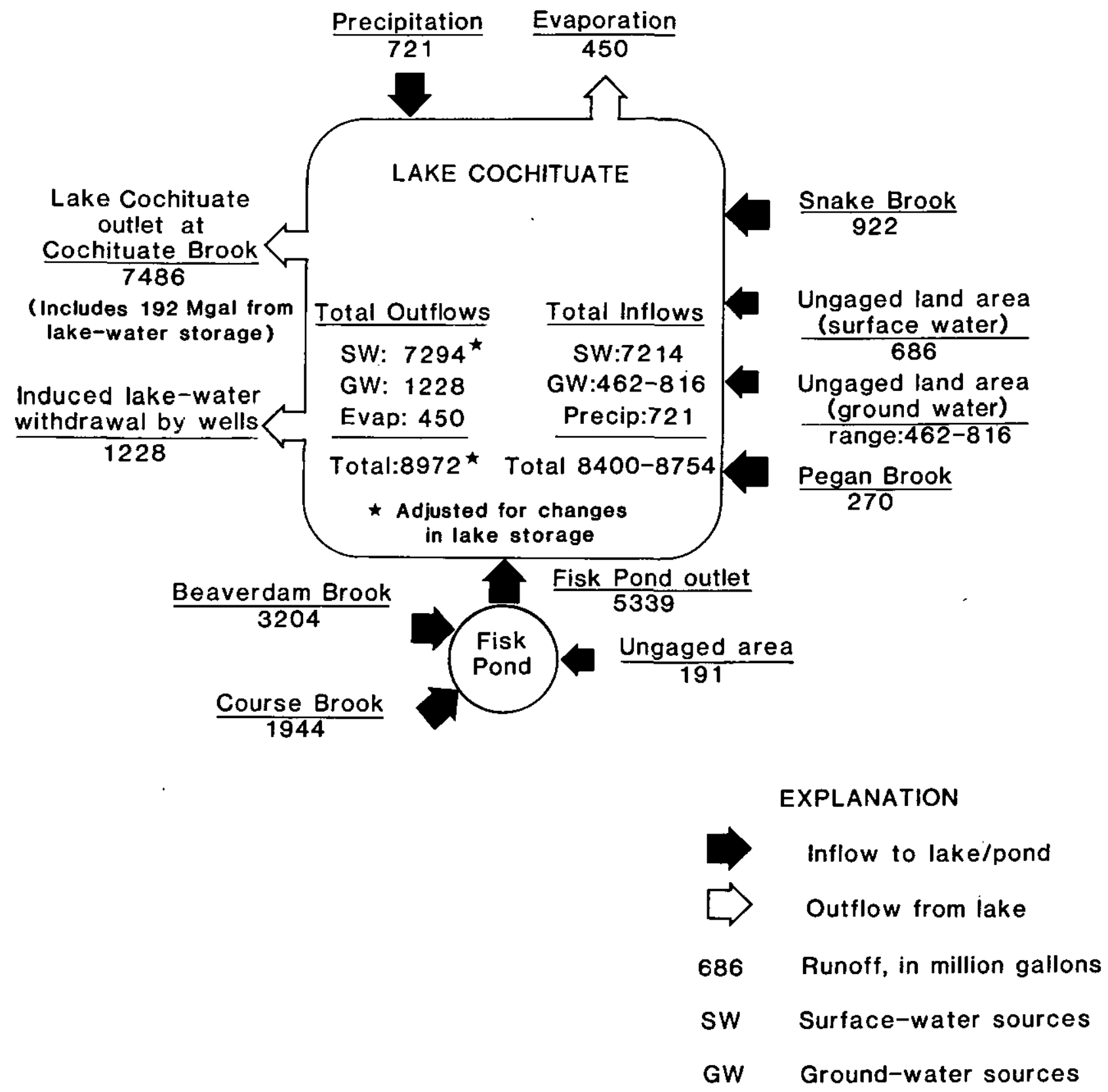

Figure 12.--Schematic diagram of water volumes entering and leaving Fisk Pond and Lake Cochituate from major sources for the period April 1978 through March 1979. 


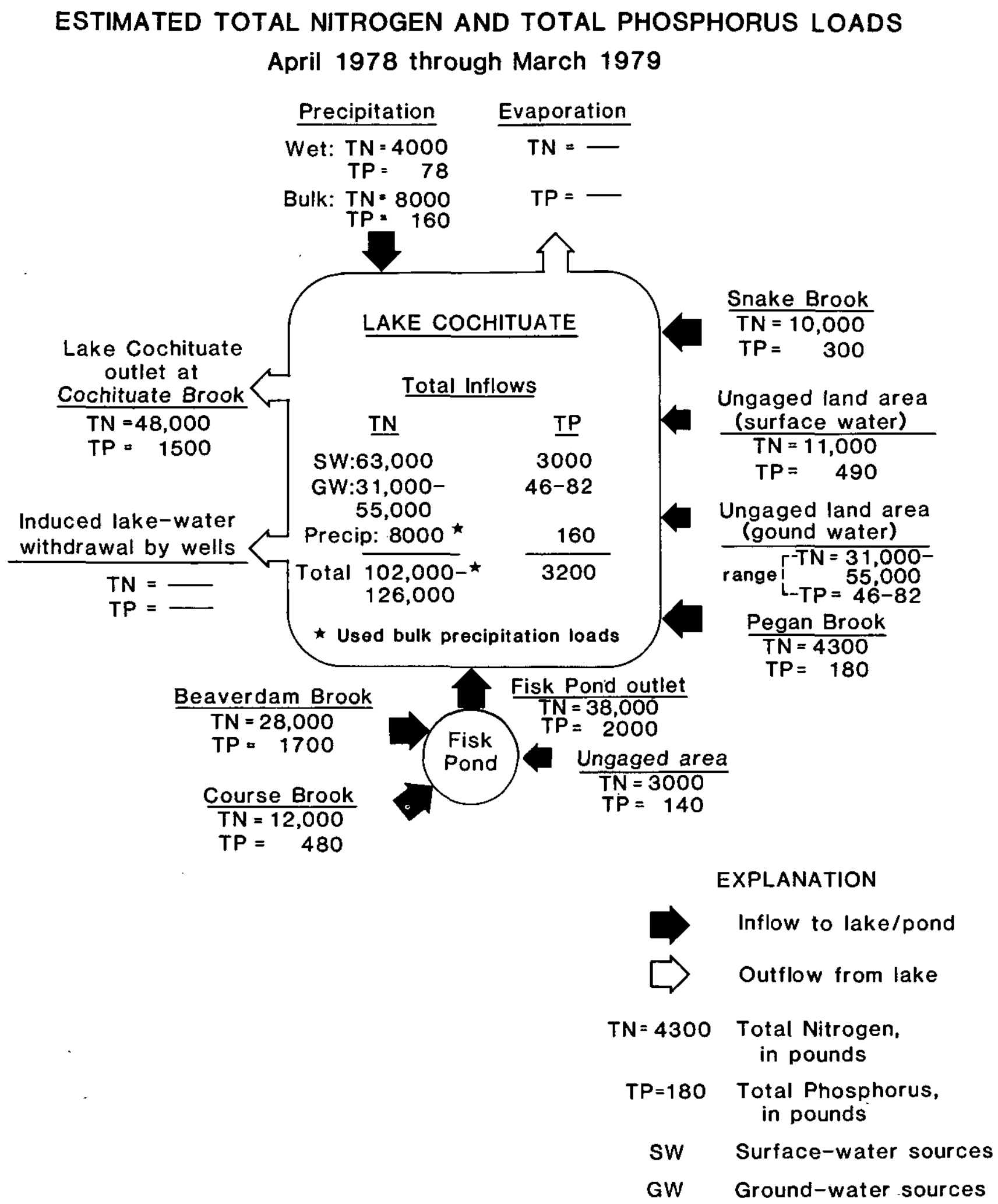

Figure 13.--Schematic diagram of total nitrogen and total phosphorus loads entering and leaving Fisk Pond and Lake Cochituate from major sources for the period April 1978 through March 1979. 
Surface water entering Lake Cochituate as compared to the sum of all water sources entering the lake is the major contributor of both water and nutrients (figs. 12 and 13). During that period, all surface-water sources are estimated to have contributed 7,217 Mgal (little over 80 percent) of water, 63,000 pounds (between 50 and 60 percent) of nitrogen, and 3,000 pounds (94 percent) of phosphorus. Of the total inputs to the lake, about 61 percent of the water drained into Lake Cochituate from Fisk Pond. This water transported a little over 30 percent of the total nitrogen load and 60 percent of the total phosphorus load. There are four principal streams contributing surface water and nutrients to the lake. Beaverdam and Course Brooks flow into Fisk Pond, and Pegan and Snake Brooks flow directly into Lake Cochituate. Of these streams, Beaverdam Brook basin is the largest single source of water and nutrients to the lake. It is estimated to contribute about 40 percent of the water, 25 percent of the total nitrogen load, and 50 percent of the total phosphorus load.

A 3.3 percent difference between the inflow and outflow volumes $(8,400$ as opposed to $8,972 \mathrm{Mgal}$, fig. 12) shows that the water balance for Lake Cochituate is well within measurement errors. This percent difference is much lower than the \pm 12 measurement error for the most accurate part of the water-balance equation, lake-water discharge.

Data from the sampling of storm sewers around Lake Cochituate were insufficient to accurately estimate nutrient loads entering the lake from this source. More data is needed before any conclusions can be presented; however, comparing the nutrient loads from the ungaged drainage area adjacent to the lake (fig. 13) to the total loads from all sources shows that nitrogen and phosphorus inflows could be 10 and 15 percent, respectively.

Ground-water inflow to Lake Cochituate occurs along its shoreline except at the north end of Lake Cochituate's North Pond where natural leakage from the lake is occurring, and at locations on the lake's Middle and South Ponds where two municipal well fields cause exfiltrating of lake water. This volume of induced lake-water withdrawal, $1,228 \mathrm{Mgal}$, represents a significant loss of water from the lake accounting for 14 percent of all the water entering the lake. Water volumes and nutrient loads, specifically the total nitrogen load, in ground water that flows into the lake along the shoreline varies considerably from a sewered site to an unsewered site (site 2 to $5 ; 196$ as opposed to 1,384 pounds per year per 1,000 feet of shoreline, respectively). However, total phosphorus loads at each site are slightly less than 1 pound.

Ground-water runoff (fig. 12) and nutrient loads (fig. 13) entering the lake along the shoreline were estimated to be slightly less than 10 percent for water, in the 30 to 40 percent range for total nitrogen, and about 2 percent for total phosphorus loads as compared to all inflows. Although the nitrogen load (31,000 to 55,000 pounds) to the lake from ground water is high given its small volume of water (462 to $816 \mathrm{Mgal}$ ), the total phosphorus load (46 to 82 pounds) is insignificant when compared to the total phosphorus load (3,200 pounds) from other sources. This high nitrogen load is at tributed largely to onsite disposal of domestic sewage; however, the associated phosphorus load from domestic sewage is being retained by the aquifer materials.

The water volumes and nutrient loads from bulk precipitation entering the lake are the smallest of all the major sources to the lake. Comparing the water volumes (fig. 12) and nutrient loads (fig. 13) from bulk precipitation to the total inflow shows that bulk precipitation contributes about 8 percent of the water volume, about 8 percent of the total nitrogen load, and about 5 percent of the total phosphorus load. These loads are based on precipitation volume to Lake Cochituate and nutrient concentration data transferred to the lake from the Great Lakes basin.

The classic equation by Vollenweider predicts that the total phosphorus load of 2,180 pounds (table 18) transported by surface water entering the lake's South Pond from Fisk Pond and Pegan Brook produces a total phosphorus concentration of $0.031 \mathrm{mg} / \mathrm{L}$ at spring overturn in South Pond. This concentration is $\mathbf{5 0}$ percent higher than the critical total phosphorus concentration of $0.02 \mathrm{mg} / \mathrm{L}$ that is commonly accepted as a sufficient 
total phosphorus concentration in lake water at the start of the growing season (spring) to sustain and to continue the eutrophic conditions that were described in the "Introduction" as present in Lake Cochituate.

\section{REFERENCES CITED}

Alley, W. M., 1977, Guide for collection, analysis, and use of urban stormwater data, a conference report: New York, American Society of Civil Engineers, 115 p.

Benson, M. A., and Dalrymple, Tate, 1967, General field and office procedures for indirect discharge measurements: U.S. Geological Survey Techniques of WaterResources Investigations, book 3 , chap. A1, 30 p.

Beskenis, J. L., Ackerman, M. T., Whit taker, G. E., and others, 1982, Lake Cochituate data and summary report, April 1976-August 1980: Massachusetts Department of Environmental Quality Engineering, Division of Water Pollution Control, 272 p.

Bodhaine, G. L., 1968, Measurement of peak discharge at culverts by indirect methods: U.S. Geological Survey Techniques of Water-Resources Investigations, book 3, chap. A3, 60 p.

Boston College Environmental Center, 1972, Water quality and urban planning in the Lake Cochituate watershed, volume 1, limnology: Boston College Environmental Center, $196 \mathrm{p}$.

Brackley, R. A., and Hansen, B. P., 1977, Water resources of the Nashua and Souhegan River basins, Massachusetts: U.S. Geological Survey Hydrologic Investigations Atlas HA-276. 1985, Hydrology and water resources of tributary basins to the Merrimack River from Salmon Brook to the Concord River, Massachusetts: U.S. Geological Survey Hydrologic Investigations Atlas HA-662.

Buchanan, T. J., 1969, Discharge measurements at gaging stations: U.S. Geological Survey Techniques of Water-Resources Investigations, book 3, chap. A8, 65 p.

Buchanan, T. J., and Somers, W. P., 1968, Stage measurement at gaging stations: U.S. Geological Survey Techniques of Water-Resources Investigations, book 3, chap. A7, $28 \mathrm{p}$.

Carter, R. W., and Davidian, Jacob, 1968, General procedures for gaging streams: U.S. Geological Survey Techniques of Water-Resources Investigations, book 3, chap. A6, $13 \mathrm{p}$.

Cortell and Associates, Inc., 1972, A research and demonstration project: Algae control by artifical mixing: Wellesley, Massachusetts, Jason M. Cortell and Associates, Inc., p. iii.

Ferris, J. G., Knowles, D. B., Brown, R. H., and Stallman, R. W., 1962, Theory of aquifer tests: U.S. Geological Survey Water-Supply Paper 1536-E, 174 p.

Franke O. L., and McClymonds, N. E., 1972, Summary of the hydrologic situation on Long Island, New York, as a guide to water-management alternatives: U.S. Geological Survey Professional Paper 627-F, 59 p.

Friedman, L. C., ed., 1978, 1979 water quality laboratory services catalog: U.S. Geological Survey Open-File Report 78-842, 499 p.

Gay, F. B., 1981, Hydrologic data of the Lake Cochituate drainage basin, FraminghamNatick, Massachusetts: U.S. Geological Survey Open-File Report 82-342, Massachuset ts Hydrologic-Data Report 23,61 p., 1 pl.

Guswa, J. H., and LeBlanc, D. R., 1981, Digital models of ground-water flow in the Cape Cod aquifer system, Massachusetts: U.S. Geological Survey Water Resources Investigations Open-File Report 80-67, 128 p.

Guy, H. P., and Norm an, V. W., 1970, Field methods for measurement of fluvial sediment: U.S. Geological Survey Techniques of Water-Resources Investigations, book 3, chap. C2, 59 p. 
Hammer, M. J., and Mac Kichan, K. A., 1981, Hydrology and quality of water resources: New York, John Wiley and Sons, 486 p.

Knox, C. E., Nordenson, T. J., 1955, Average annual runoff and precipitation in the New England-New York area: U.S. Geological Survey Hydrologic Investigations Atlas HA-7.

Kuntz, K. W., 1981, Atmospheric bulk precipitation in the Great Lakes Basin: Inland Waters Directorate, Water Quality Branch, Burlington, Ontario, Scientific Series No. $115,27 \mathrm{p}$.

Linsley, R. K., Jr., Kohler, M. A., Paulhus, J. L. H., 1975, Hydrology for engineers: New York, McGraw-Hill Book Co., 482 p.

McBride, M. S., and Pfannkuch, H. O., 1975, The distribution of seepage within lakebeds: U.S. Geological Survey Journal of Research, v. 3, no. 5, Sept.-Oct. 1975, p. 505-512.

Nelson, A. E., 1974a, Surficial geologic map of the Framingham quadrangle, Middlesex and Worcester Counties, Massachusetts: U.S. Geological Survey Geologic Quadrangle Map 1176.

$1974 \mathrm{~b}$, Surficial geologic map of the Natick guadrangle, Middlesex and Norfolk Counties, Massachusetts: U.S. Geological Survey Geologic Quadrangle Map 1151.

Reid, G. K., and Wood, R. D., 1976, Ecology of inland waters and estuaries: New York, New York, D. Van Nostrand Co., 485 p.

Sawyer, C. N., 1947, Fertilization of lakes by agricultural and urban drainage: New England Water Works Association Journal, v. 61, no. 2, p. 109-127.

Skougstad, M. W., Fishman, M. J., Friedman, L. C., Erdmann, D. E., and Duncan, S. S., eds., 1979, Methods for determination of inorganic substances in water and fluvial sediments: U.S. Geological Survey Techniques of Water-Resources Investigations, book 5, chap. A1, 626 p.

Sylvester, M. A., and Brown, W. M., 1978, Relation of urban land-use and land-surface characteristics to quantity and quality of storm runoff in two basins in California: U.S. Geological Survey Water-Supply Paper 2051, 49 p.

U.S. Council on Environmental Quality, 1975, Environmental quality, 1975--Sixth annual report of the Council on Environmental Quality: Washington, D.C., U.S. Government Printing Office, $763 \mathrm{p}$.

U.S. Environmental Protection Agency, 1971, Nitrates: U.S. Environmental Protection Agency, Water Programs Office, Water Quality Standards Division, Nov. 1971, 40 p. 1975, National interim primary drinking water regulations: Federal Register, v. 40, no. 248, Wednesday, December 24, 1975, Part IV, p. 59566-59588.

1976, Quality criteria for water: U.S. Environmental Protection Agency, 256 p.

U.S. Geological Survey, issued monthly, Current water resources conditions in central New England: U.S. Geological Survey, Boston, Mass.

Volckmann, Richard P., 1975, Surficial geologic map of the Holliston quadrangle, Middlesex, Norfolk, and Worcester Counties, Massachusetts: U.S. Geological Survey Geologic Quandrangle Map 1217.

Walton, W. C., 1962, Selected analytical methods for well and aquifer evaluation: Illinois State Water Survey Bulletin 49, 81 p.

Wetzel, R. G., 1975, Limnology: Philadelphia, Pennsylvania, W. B. Saunders Co., 743 p. Winter, T. C., 1981, Uncertainties in estimating the water balance of lakes: American Water Resources Association Water Resources Bulletin, v. 17, no. 1, February 1981, p. 82-115.

Wood, W. W., 1976, Guidelines for collection and field analysis of ground-water samples for selected unstable constituents: U.S. Geological Survey Techniques of WaterResources Investigations, book 1, chap. D2, 24 p. 


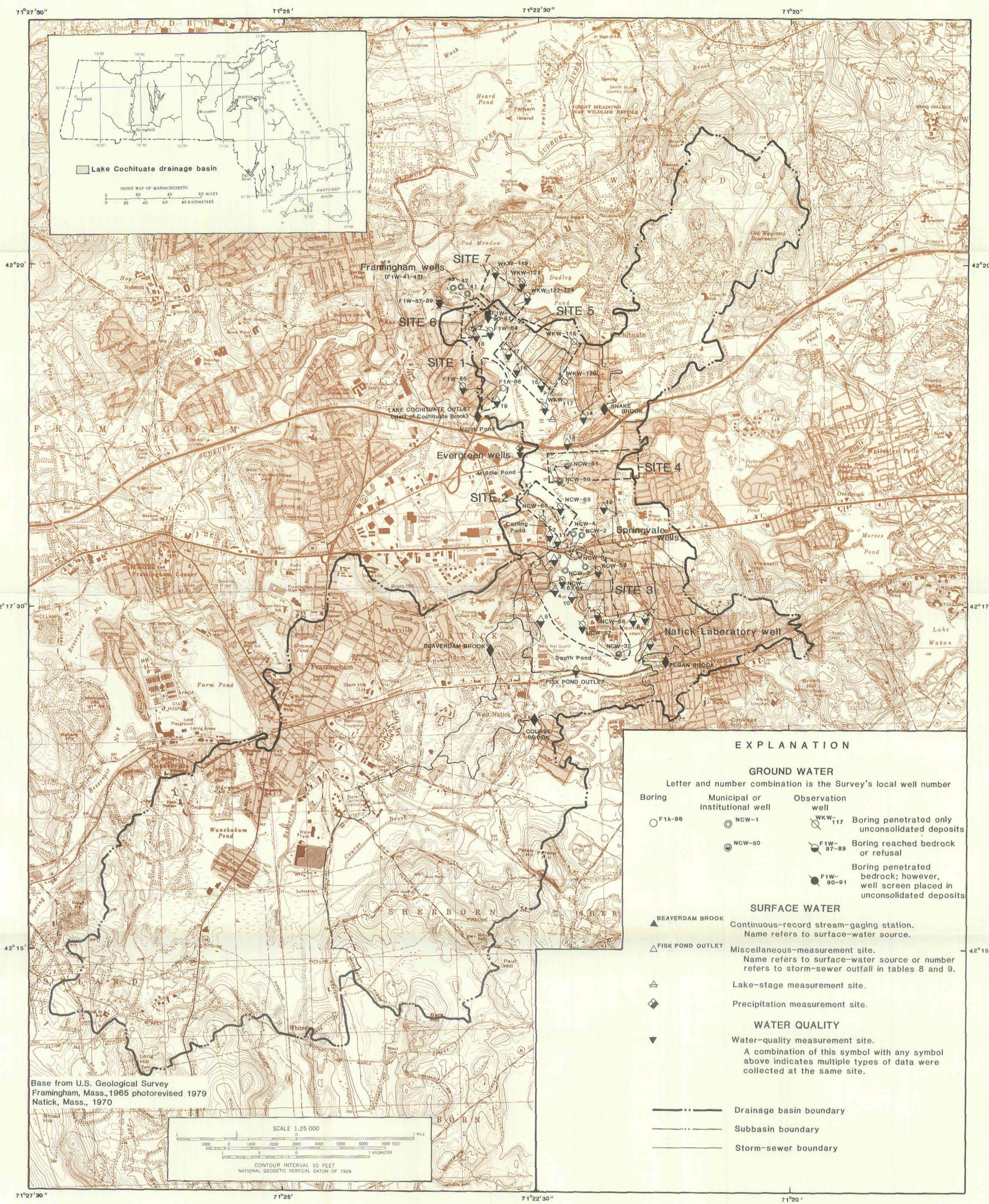




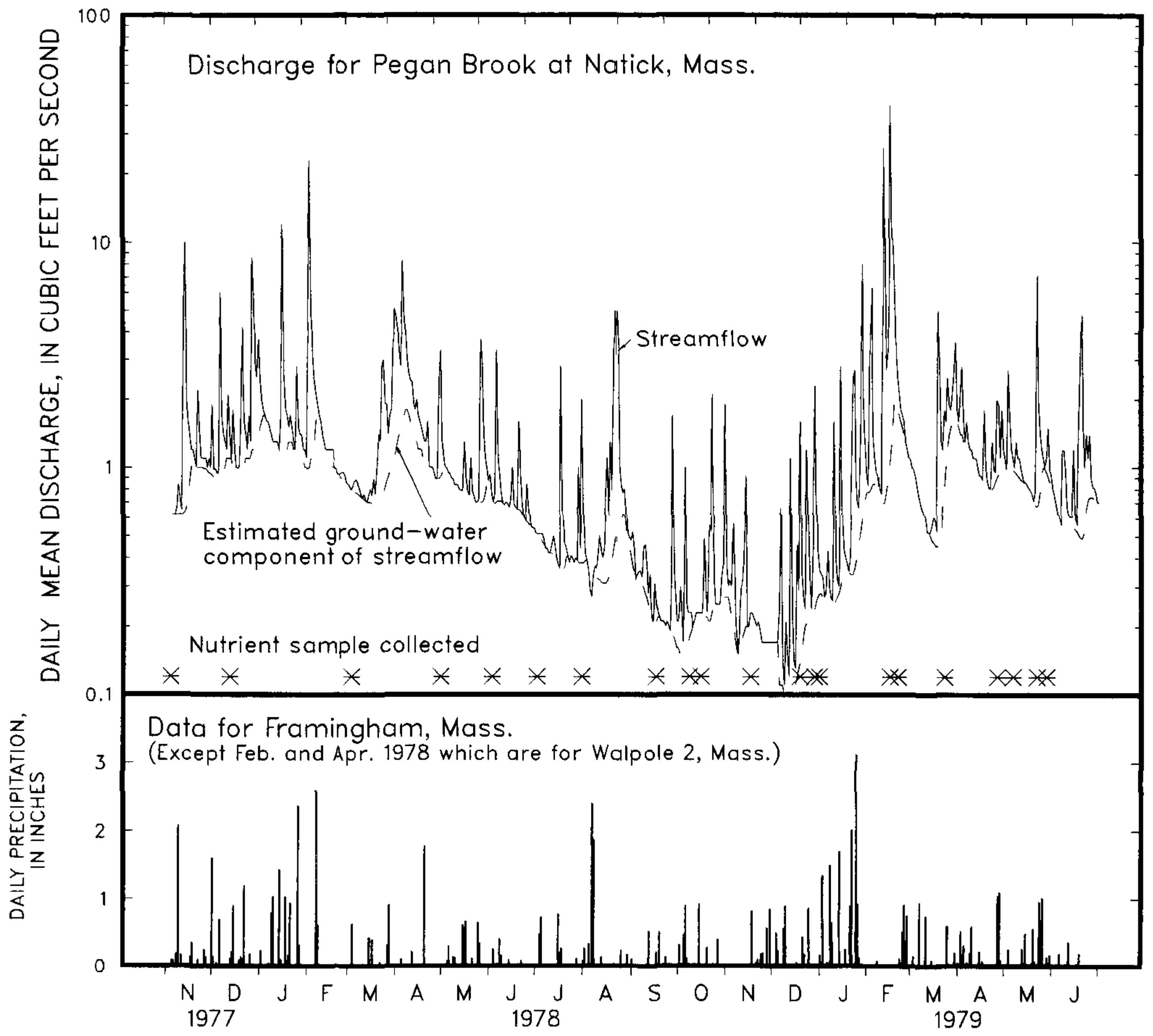

Daily mean streamflow, estimated daily mean ground-water discharge, and dates of nutrient sample collection at Pegan Brook, and precipitation at National Weather Service Station in Framingham. 